\title{
الفلسفة الإلهية عند إمام الحرمين الجويني وتطورها بين الأشعرية والمعتزلة
}

\author{
د. عادل سالم عطية جاد اللّه \\ مدرس الفلسفت الإسلاميتي \\ كليت دار العلوم ـ جامعت الفيوم الفسليف
}




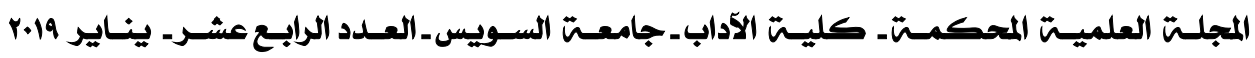




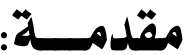

يمثل الجانب الإلهي جزءا لا يتجزأ من البنبة الفكرية والعقدية للمدارس

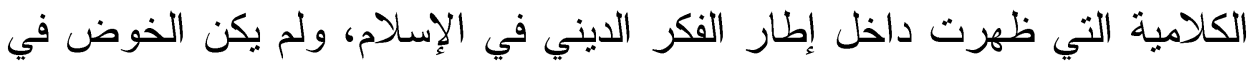

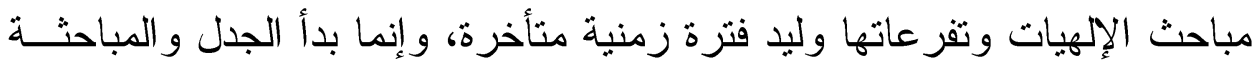
حول هذه الشكلة في نهاية القرن الأول الهجري وبدايات القرن الثاني.

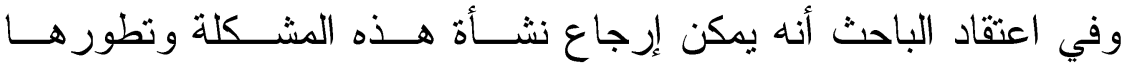
و إنضاجها في التفكير الكلامي إلى سببين رئيسين متداخلين: أحدهما سبب داخلي، نابع من داخل البيئة الإسلامية وديناميكية الحر الك المجتمعي الإسلامي، حيث إنها

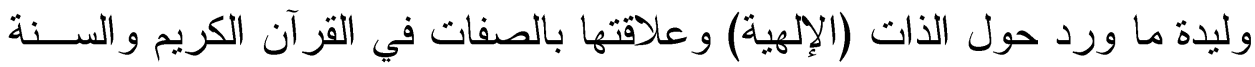

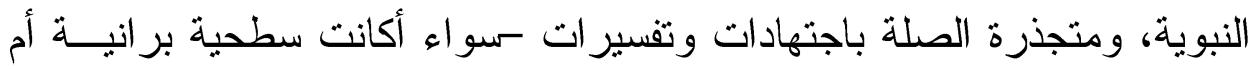
عميقة جو انبة- دارت حول فهم هذه النصوص الدينية وتعقلها.

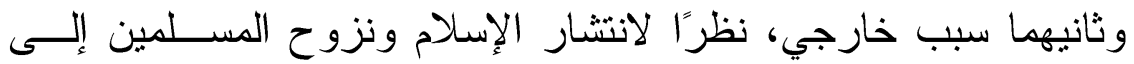

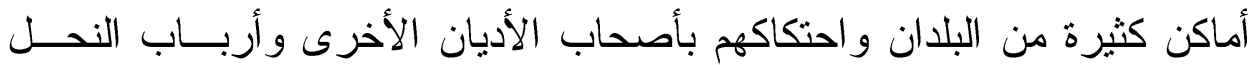

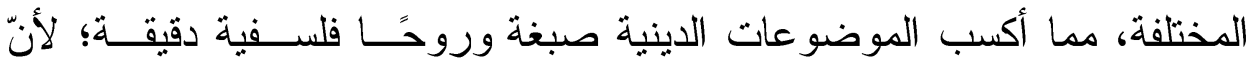

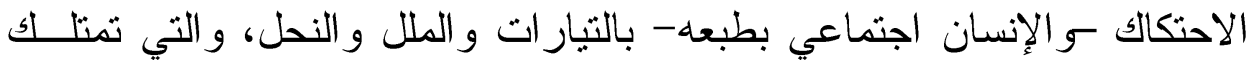

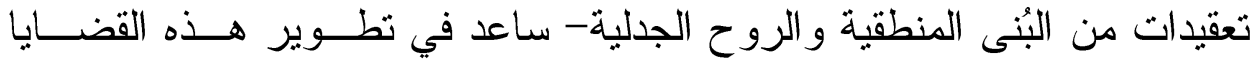

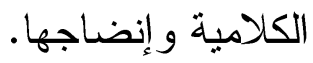

أما موقف الأشاعرة من المعتزلة في القرن الخامس الهجري خاصة لم

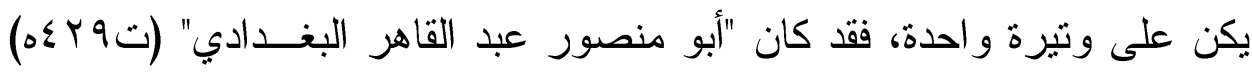

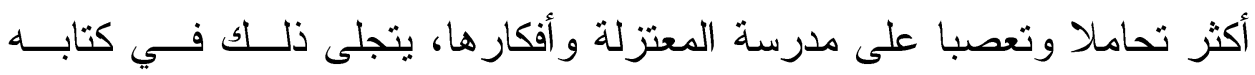
(الفرق بين الفِرق)، بينما انحسرت -ـإلى حد كبير - حدة الخلاف و الصر اع بــين

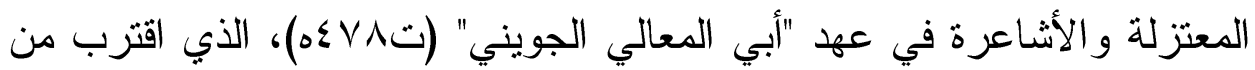
فلسفة مدرسة المعتزلة و اتجاهها العقلانيّ-التأويلي في مسائل كلامية متعددة نحو إثبات وجود الله تعالى بالأدلة العقلية، وتأويل الصفات الخبرية بحثا عن التنزيه، 
وتأييده لفكرة الأحوال في بيان العلاقة بين الذات الإلهية وصفاتها، ومسألة خلق الأفعال، وكذا في موقفه من الاليل النقلي وحجيته.

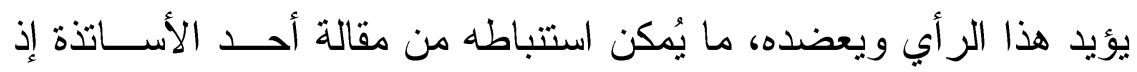

يقول:افَترَت خصومة الأشاعرة للمعتزلة لدى الجويني، بل ستجده ينـبعهم فـي بعض آرائه، لقد أدرك أنّ هناك طائفة أشند خطرًا على الدين هــــ الفلاســفة، فاتجه بمسار المذهب الأشعري إلى معارضتهمه|"(').

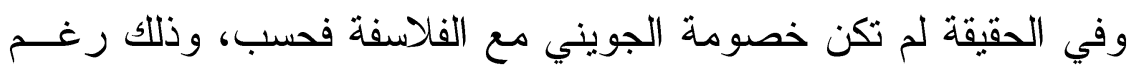
إفادته من أطروحاتهم ومنطقهم الأرسطي أحيانًا، بل وجه سهام نقده تجاه تيار ات المشبهة و الكرّامية و غُلاة المجسمة و الحشوية و القائلين بالحلول. وهذا المسلك -

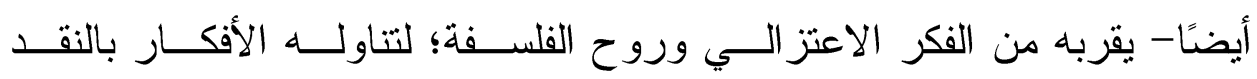

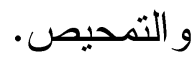
بالإضافة إلى ذلك، فإنّ صياغته لكتاب (الإرشاد إلى قو اطع الأدلة فـي

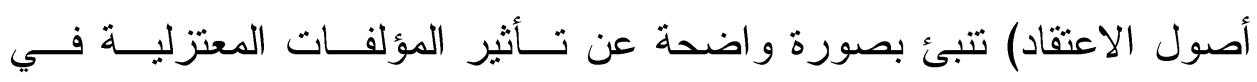
كتاباته(؟). وفي قضية حدوث العالم توسع الجويني في كتابه (الشامل في أصول

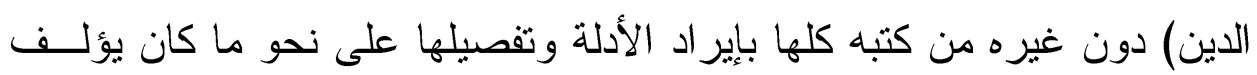

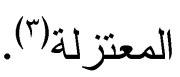

(') صبحي، أحمد محمود. في علم الكلام، دراسة فلسفية لآراء الفرق الإسلامية فــي أصـــول

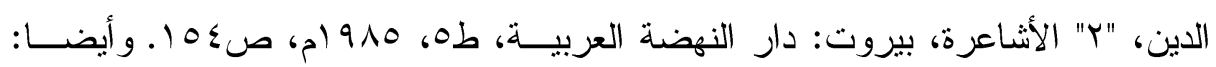
صسז ו.

غرديه، لويس، والأب جورج قنو اتي. فلسفة الفكر الديني بين الإسلام و المسيحية، نقله إلى

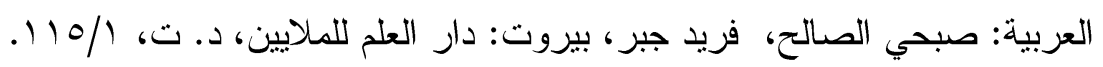

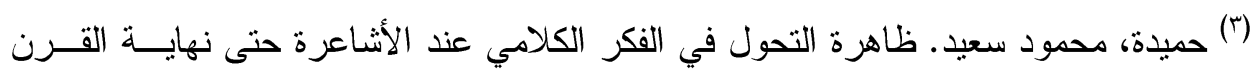

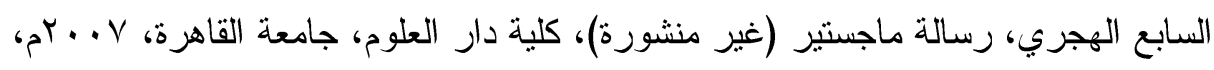


تتمثل هذه الأسباب في عدد من الدوافع، وذلك على النحو التالي:

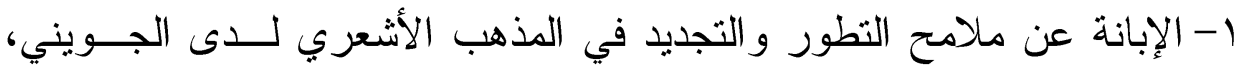

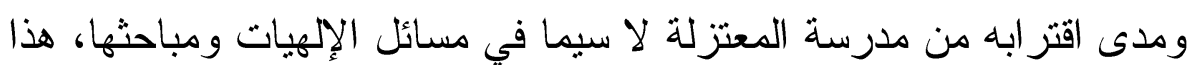

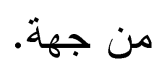

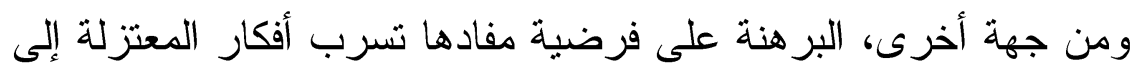

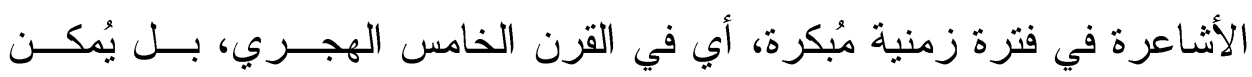

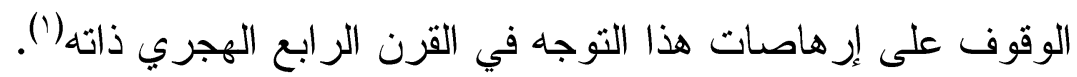

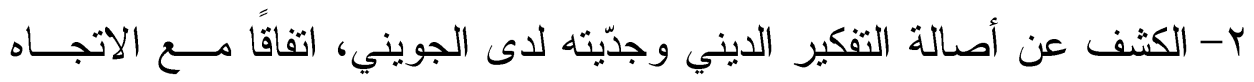

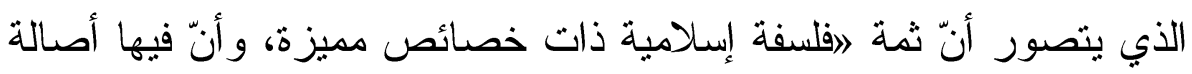

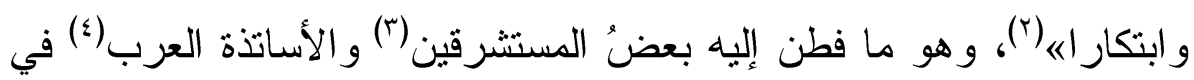

(') وليس الأمر -كما يتصور أحد الأساتذة- بأنّ أفكار المعتزلة تسربت إلى مؤلفات الأشاعرة

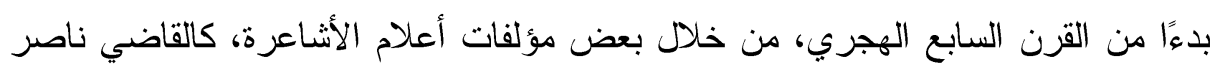

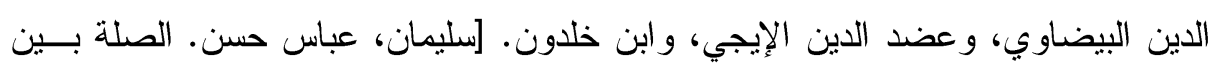

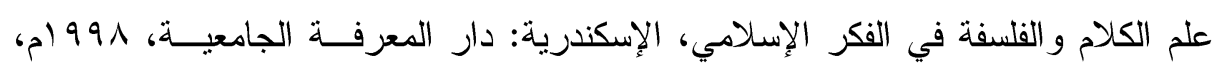

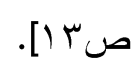

مدكور، إيراهيم. في الفلسفة الإسلامية منهج وتطبيقه، القـاهرة: سـميركو، طن، د. ت،

$$
\text { r } r / r
$$

"(") ومن جانبه وصف "هنري كوربان" علم الكلام بأنه الفلسفة الددرسية في الإسلام، وهو جدل

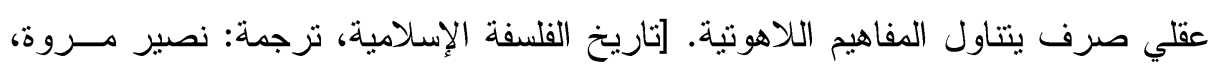

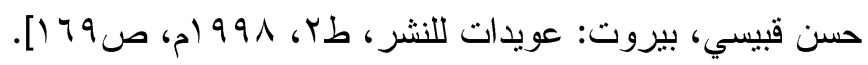

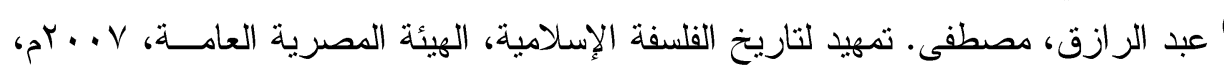

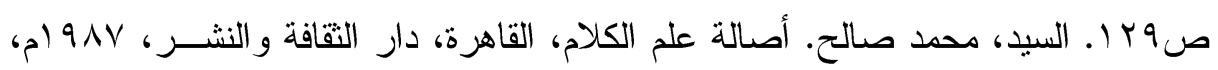

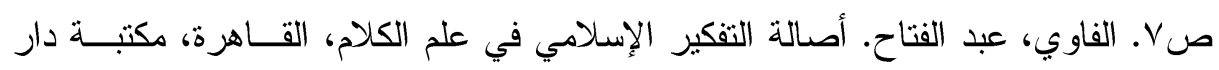

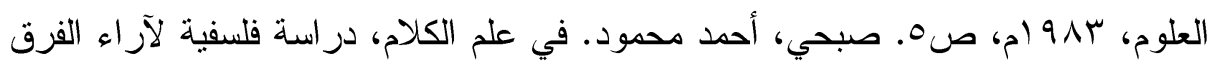

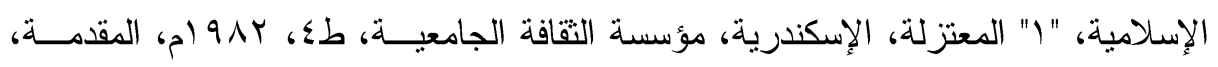

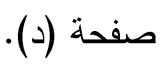


اعتبار علم الكلام فلسفة حقيقية دُعبرة عن الروح العربية، فيقول المستشرق الفرنسي إرنست رينان E.Renan (توفي raq (م): افي الفرق الدينية التي

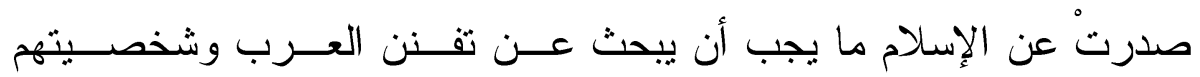

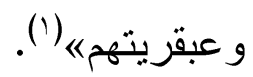

س- إظهار المَنْحى النقدي المتجذر في البنية العقلية للجويني، الذي تمتع بموقـع

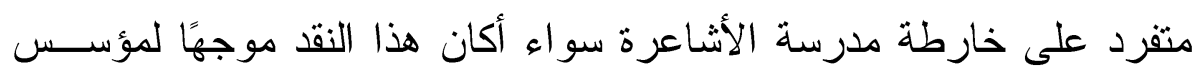
المذهب الأشعري وتلاميذه أم للفلاسفة والنحل و التيار ات التي كانت أفكار ها ذات صدى مؤثر آنذاك.

ع - البر هنة على استمر ارية الروح الاعتز الية وعطائها المتجدد في مدرسة أبـي

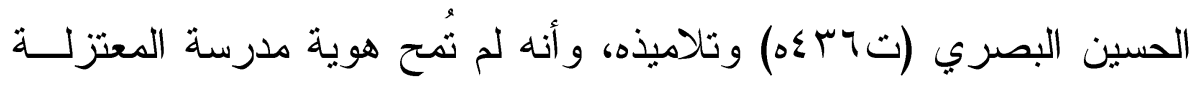

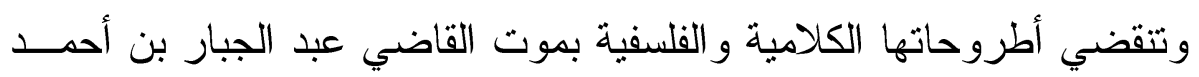

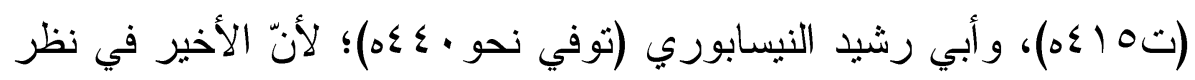

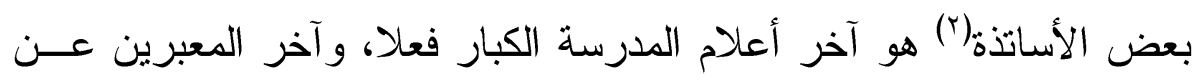

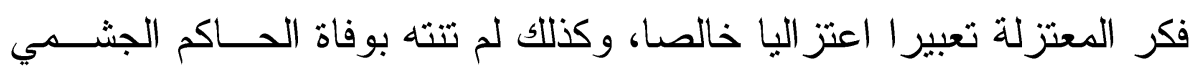

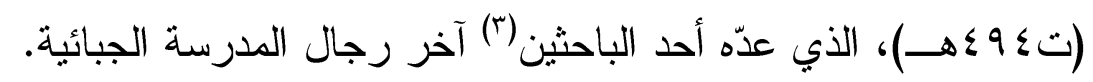

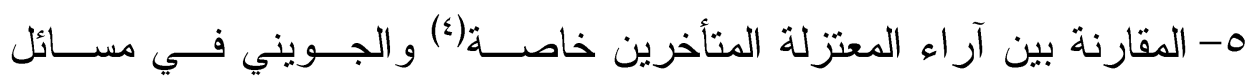
الإلهيات، و إبراز جو انب الاتفاق بينهم.

(1) رينان، إرنست. ابن رشد و الرشدية، نقله إلى العربية: عادل زعيتر، القاهرة: دار إحيــاء

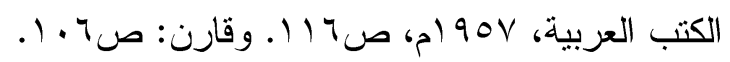

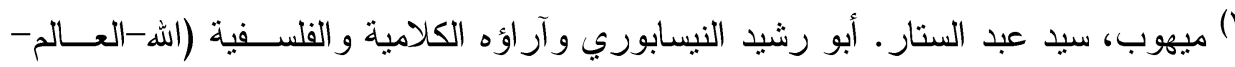

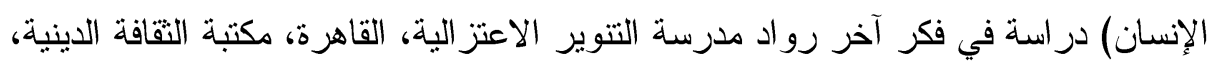

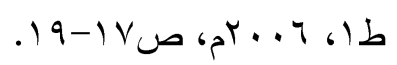
(َ) زرزور، عدنان. الحاكم الجشمي ومنهجه في التفسير، بيروت: مؤسسة الرســالة، د. ت،

(؛) كالقاضي عبد الجبار، و أبي الحسين البصري، وابن الملاحمي، و الزمخشري. 
منهج البحث:

كان المنهج الوصفي التحليلي هو الأداة المحورية التي وظفتُ في بيــان تطــور

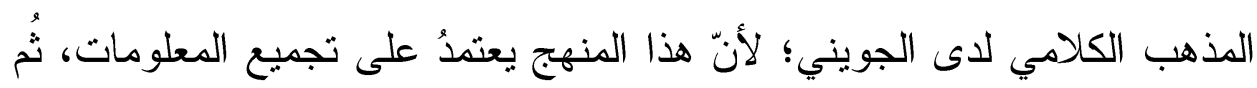

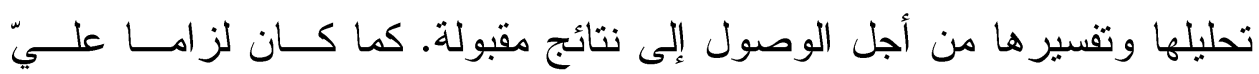

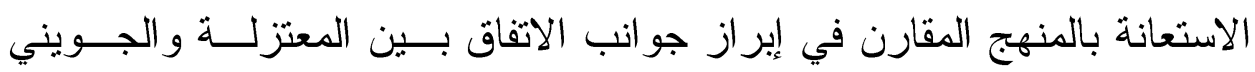
وبخاصة في دراسة المباحث الإلهية.

\section{خطة البحث:}

جاء هذا البحث موسومًا بعنوان: 》الفلسفة الإلهية عند إمسام الحسـرمين

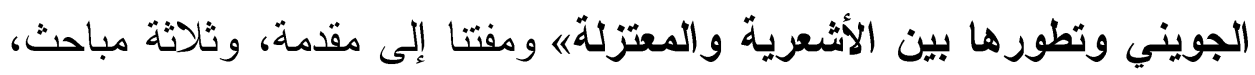
وخاتمة تضمنت أبرز نتائجه.

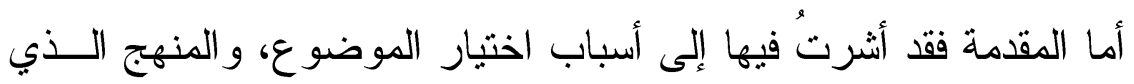
سلكته في تحليل الآراء، وخطة البحث.

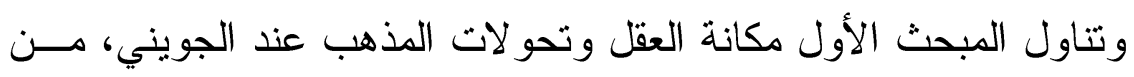

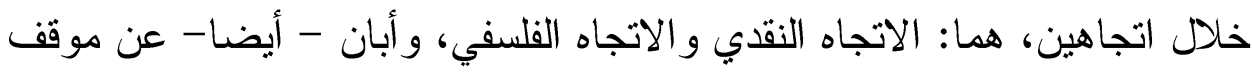
الجويني من الدليل النقلي و علاقته بالعقل. ثم جاء المبحث الثاني ليعرض للتصور الإلهي عند الجويني ومصــادره الاعتز الية من خلال مناقثة مجموعة من القضايا الكلامية، على النحو التالي: ثانيا: التنزيه عند الجويني

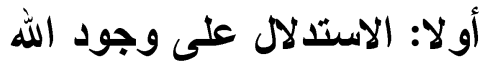

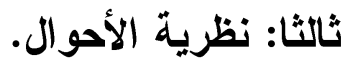

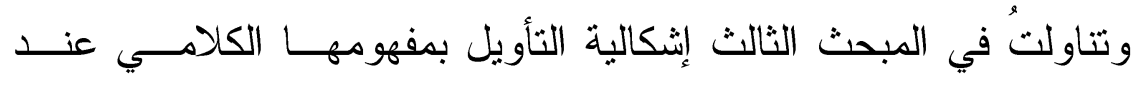
الجويني من خلال قضية الصفات (الخبرية)، مبينا مدى اقتز ابــهـ مــن التفكيــر الاعتز الي في تأويل الصفات الخبرية.

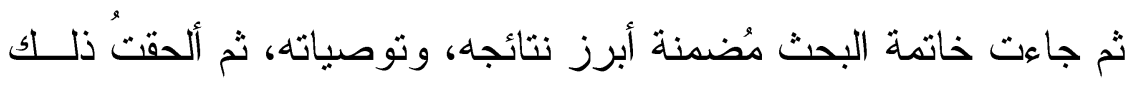
كله بقائمة المصادر و المر اجع. 


\section{المبحث الأول \\ مكانة العقل وثحولات المذهب لدى الجويني}

\section{أولا: الجويني نقطة تحول في مسار المذهب الأشعري:}

إمام الحرمين الجويني(')هو أحد المبرزين في علم الكلام والفقه وأصولهي

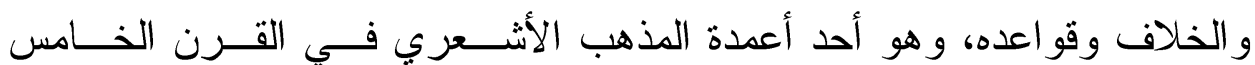
الهجري، وكان تفكيره منسمًا بنز عة فلسفية عميقة(؟)، معتمدًا على استخدام العقل وكل وأدلته في تفهم النصوص الدينية وتأويلها. ويُمتل حلقة مهمة من حلقات تطور المذهب الأشعري، إن لم تكن حلقـــة

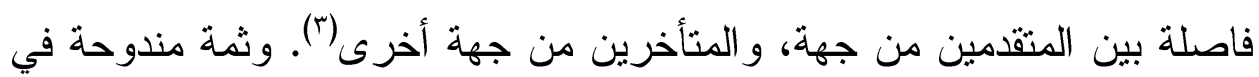

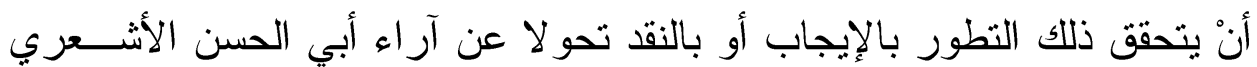
. (ت) (ت بيد أنّ أبا بكر الباقلاني (ت م ـعه) كان أسبق زمنا من الجــويني فــي تعديل مذهب أبي الحسن الأشعري من بعض الوجوه، و إلى ثقريبــهـ مــن رأي لئي المعتزلة.

(') هو عبد الملك بن عبد الله بن يوسف بن محمد بن عبد الله بن حيويه الجويني، النيسابوري،

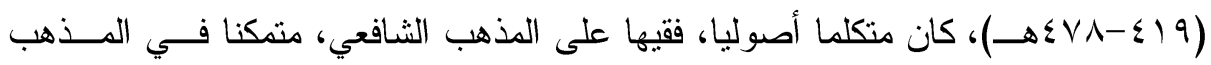
و الخلاف ومجالس النظر، جادا في استتباط الغوامض، وتحقيق المسائل. [الســـبكي، تـــاج الدين. طبقات الثافعية الكبرى، تحقيق: محمود الطناحي، عبد الفتاح الحلو، القاهرة: مطبعة عيسى البابي الحلبي، طا، ـ79 (م، 170/0 وما بعدها. ابن عساكر الدمشقي. تبيين كذب

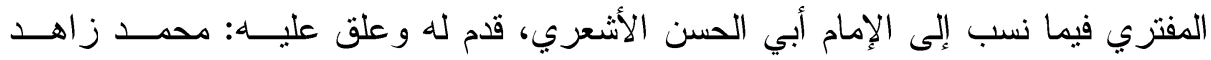

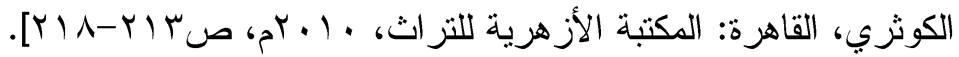
(r) النشار ، علي سامي. مقدمة تحقيق كتاب الشامل في أصول الدين، للجويني، حققه وقدم له: علي سامي النشار، فيصل عون، سهير مختار، الإسكندرية، منشــأة المعــارف، 979 (م، صن

(1) حميدة، محمود. ظاهرة التحول في الفكر الكلامي، رسالة ماجستير، صـ ـ ـ . 
و الدليل على ذلك أنّ الباقلاني رغم موقفه النقدي الصريح من المعتزلة،

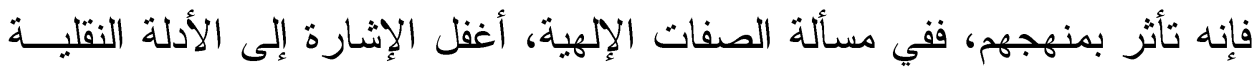
في عرض بعض الصفات مثل: الحياة والعلم، وطفق يستنبطها استنباطا عقليـا

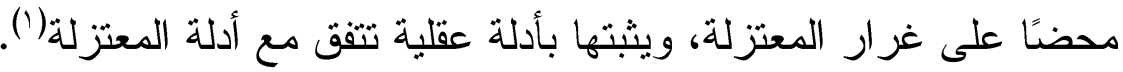
ينضاف إلى ذلك، أنه رغم تردده في التعلق بقياس الغائب على الثاهد،

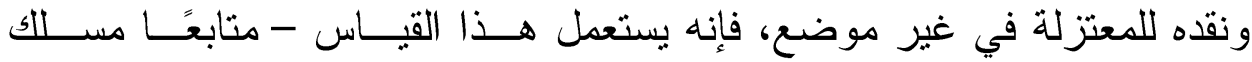

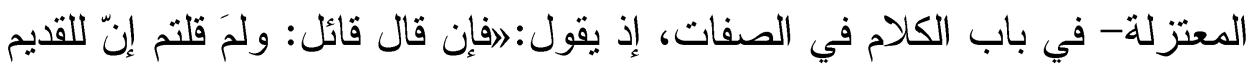

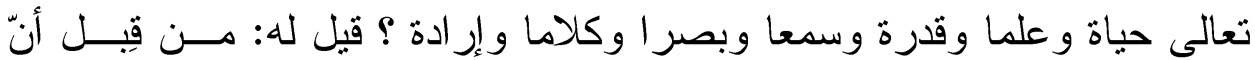
الحي العالم القادر منا إنما كان حيا عالما قادرا متكلما مريدا من أجل أن له حياة و علما وقدرة...فوجب أن يكون الباري سبحانه ذا حياة و علم وقدرةها(كان. أما ملامح التحول لدى الجويني فيمكن رصدها في الأمور التالية:

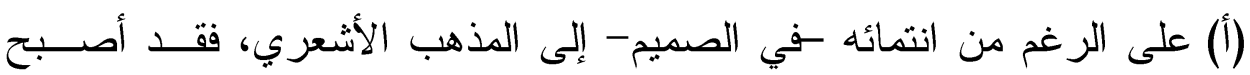

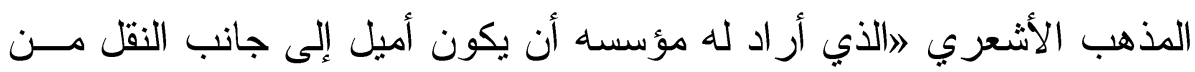

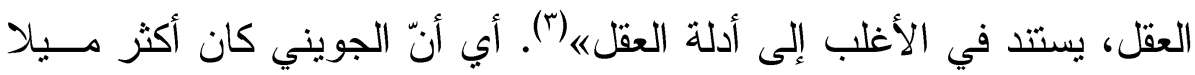

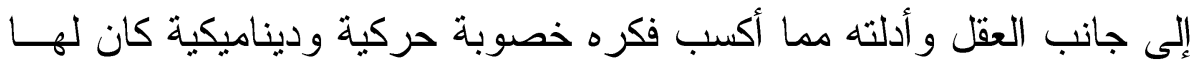
أثرها في تقرير الآراء ونقدها.

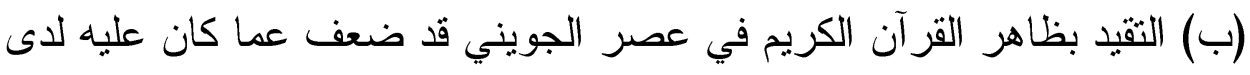
أبي الحسن الأشعري (ت ع باه)، فلقد أصبح علم الكلام أرحب صدرًا وأوسع

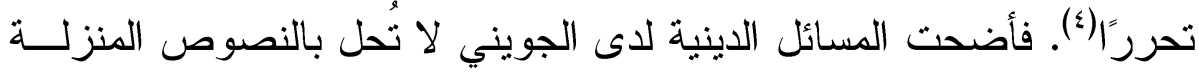
فقط، بل بوساطة العقل (0) وتقرير اته أيضًا.

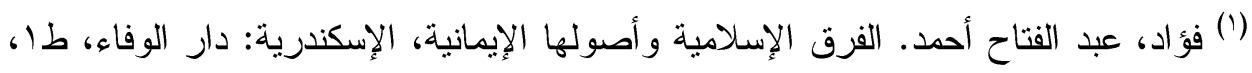
r r I-r

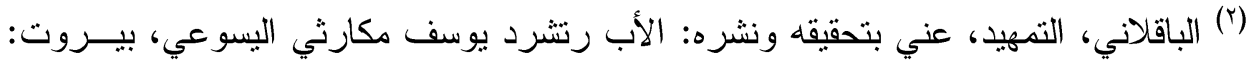

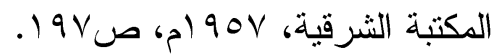

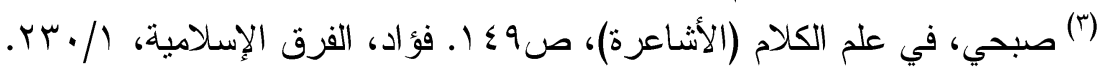

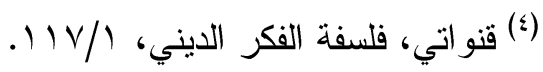

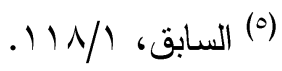


ولعلّ هذا اللجوء النادر إلى أدلة القرآن الكريم كان بسبب غلبــة فكـرة الــــور

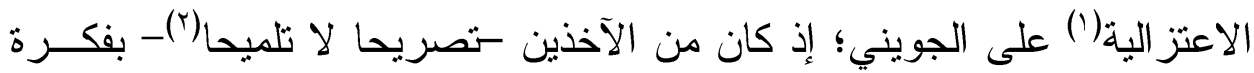
الدور من الأشاعرة()، بل إنّ الاستقرار الكامل لها في المذهب الأشعري، وتمام

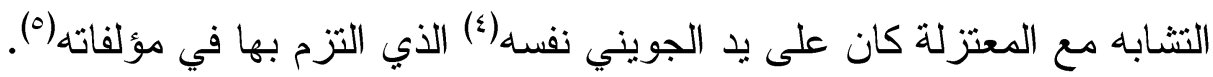

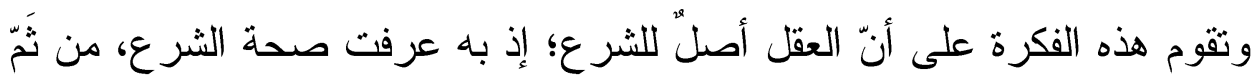

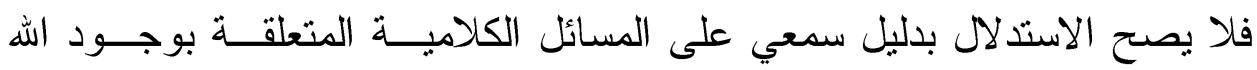

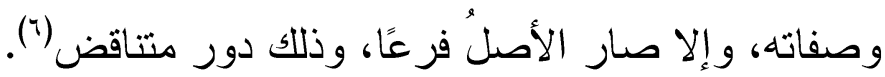

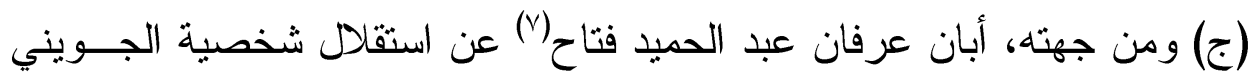
الفكرية، وأنه لم يقف عند حدود التقليد لمذهب الأشعري(^)، وفي رأيه أنــهـ

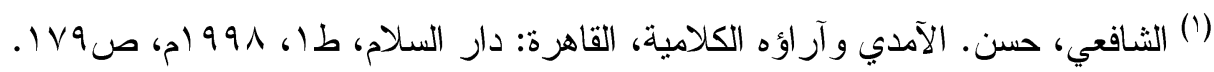

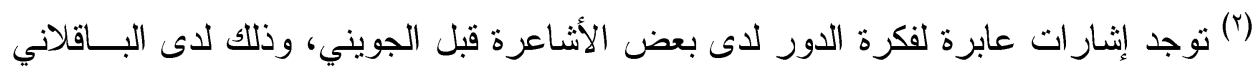

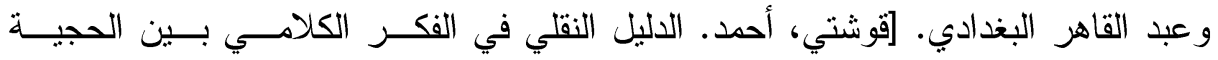

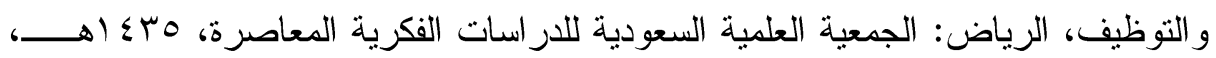
ص ص

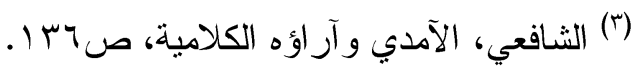

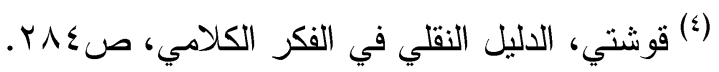

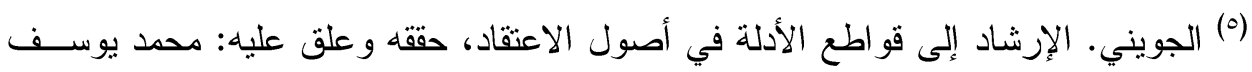

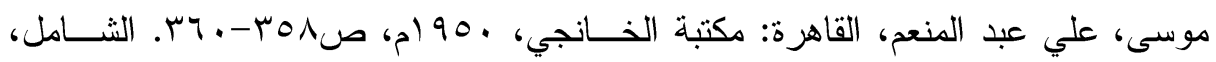
ص19 ז.

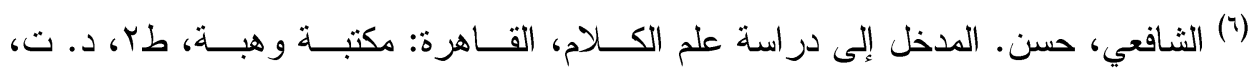
ص101)

(V) عبد الحميد، عرفان. فلسفة الفكر الديني وجهود إمام الحرمين فيها، ضـــمن كتــاب نــدوة

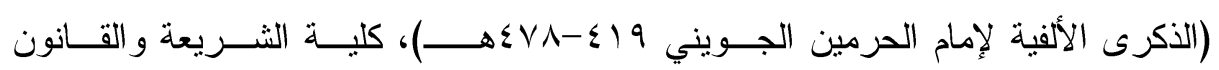

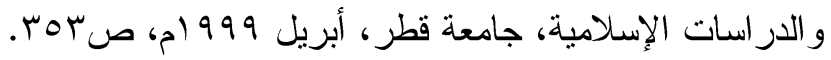

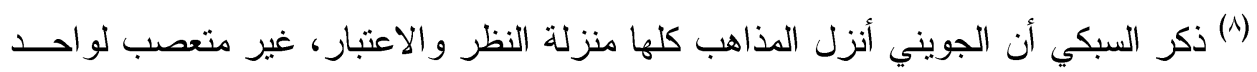

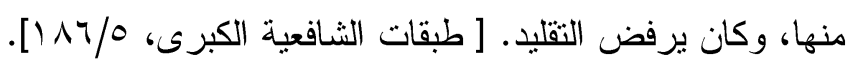




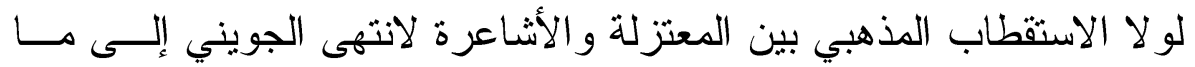
يُقرب من القول بالحسن و القبح العقليين.

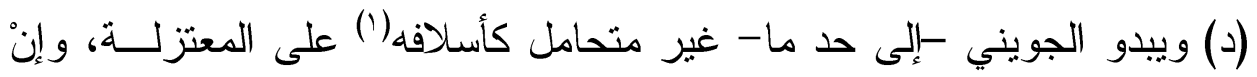

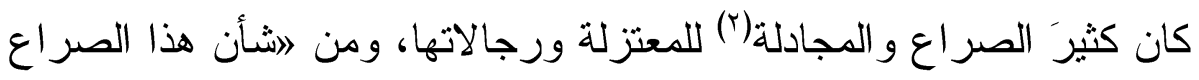

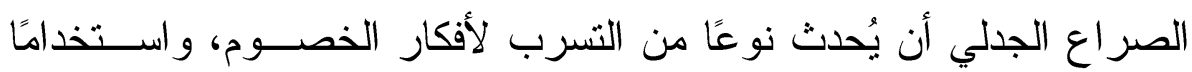

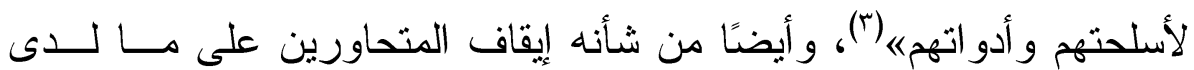
الطرف الآخر من ضعف وخلل.

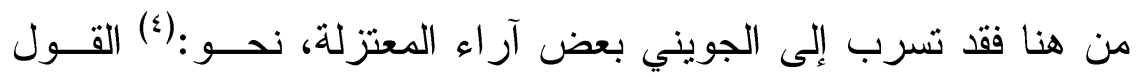

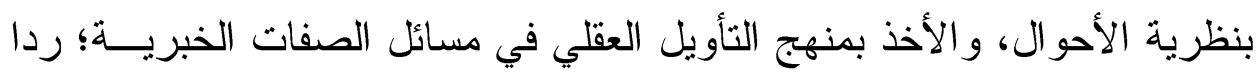
للمشبهة و مذاهبهم.

(1) يبدو للناظر بدقة في أغلب مؤلفات أبي الحسن الأشعري نفسه أنهــا بمثابــة ردود علــى

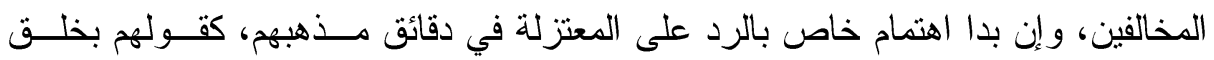
القر آن، ونفي الرؤية، وغير هما من المسائل.

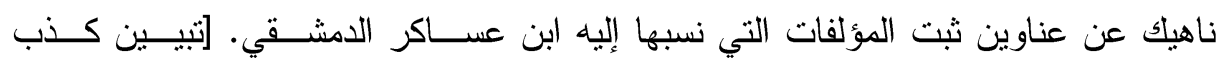

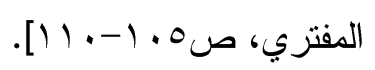

(r) ذهب بعض الباحثين إلى أنّ تواصل الحوار بين الأطر اف المختلفة، والاطلاع على أدلـــة

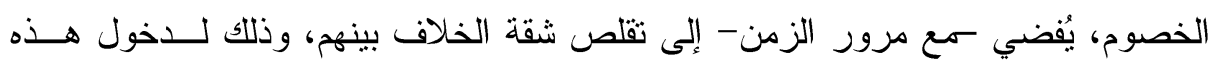

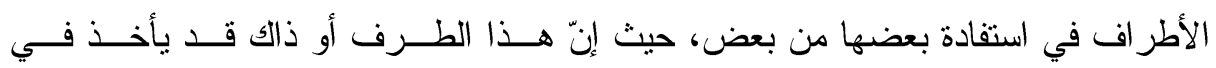

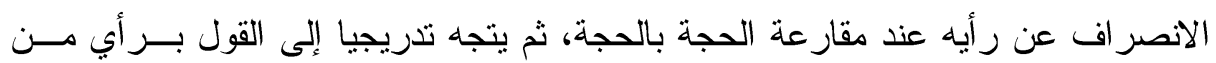

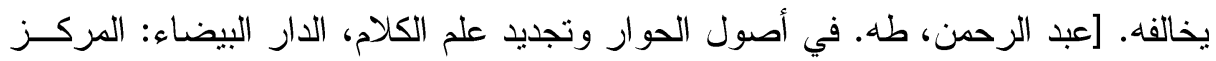

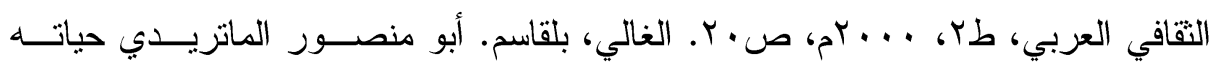

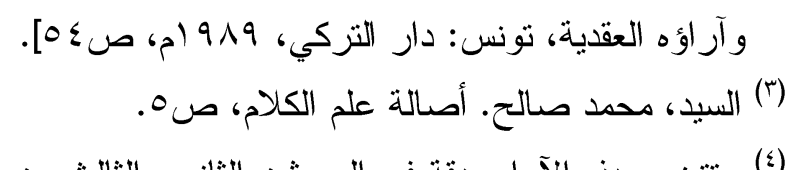

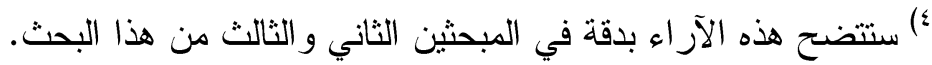


و لا شك أنّ الجويني كان أعنف من أسلافه من الأشـاعرة في معارضـــة

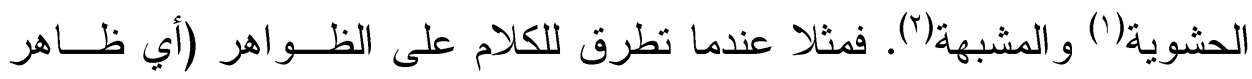
النصوص الدينية)، إذ به يقول: لوقد صرح بالاسترواح إليها الحشوية الرعــاع

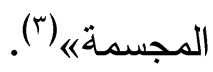

وفي رأي الباحث أنّ الجويني اطلع على فكر المعتزلة، وكــان و اعيــا بمقالاتهم(؛)، ذا نظرة موضو عية في تقرير بعض آرائه، ففي مســألة الحسـن

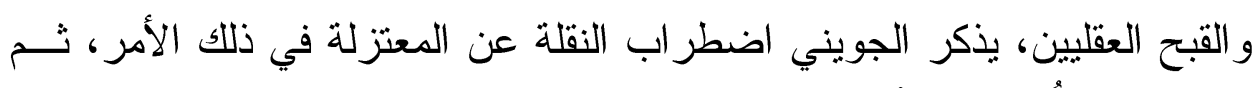

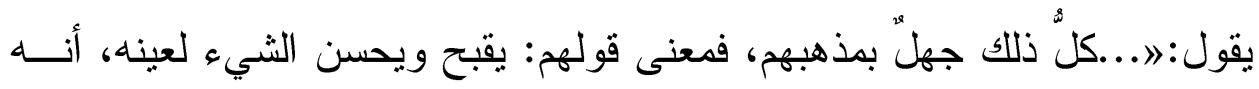
يدرك ذلك عقلا من غير إخبار مخبرها(ن). (هـ) كان الأشاعرة قبل الجويني يحترزون بأصولهم عن منطق أرسطو؛ فألف

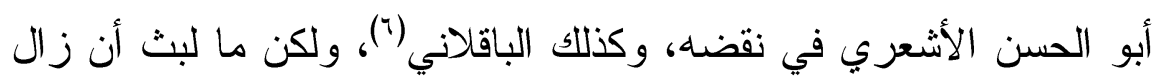
هذا الاحتر از على يد الجويني، الذي رغم مخالفته للمنطق الأرسطي فـي ولي

(') هم فريق من المتمسكين بظواهر النصوص وحرفية الألفاظ، قالو ا: إنّ طريق معرفة وجود

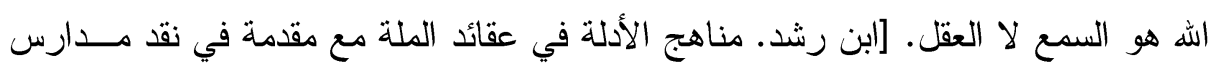

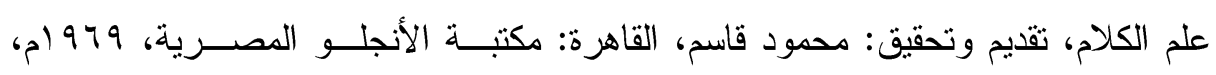

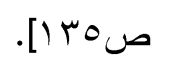

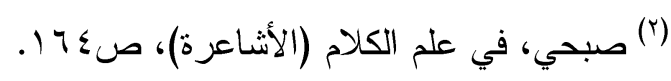

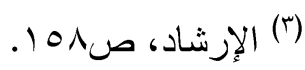

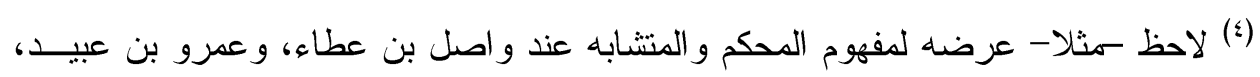

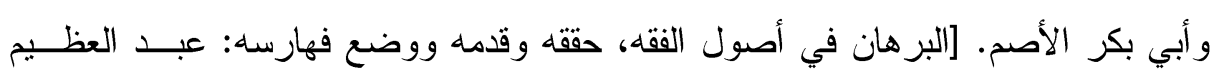

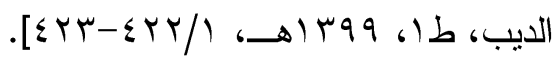

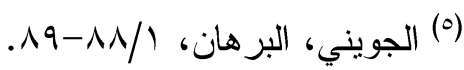

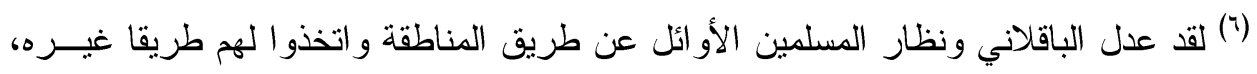

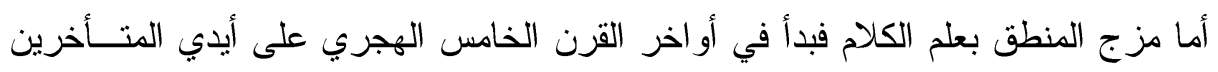

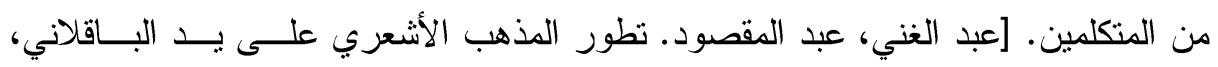

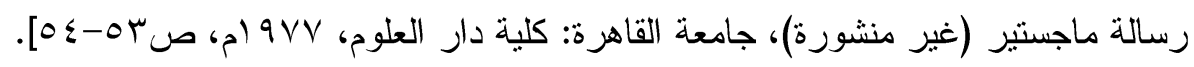


نقاط، فإنه تأثز به إلى حد ما('). بل قد نجد عنده أول محاولة لمزج منطق أرسطو بأصول الفقه(r) الذي هو شديد الصلة بعلم الكلام.

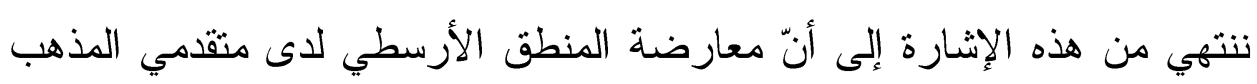

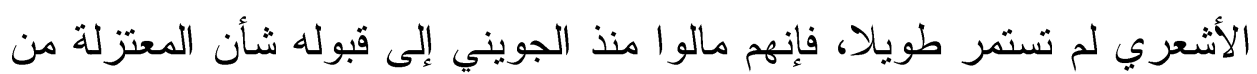

قبل (r) (1) (1)

\section{ثانيـ الدليل النقلي عند الجويني وعلاقته بالعقل:}

(أ) قام المذهب الأشعري منذ تأسيسه على دعامتين من النقل و العقل، و إذا كـــان

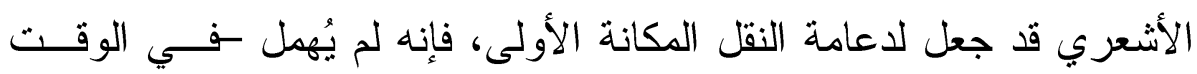

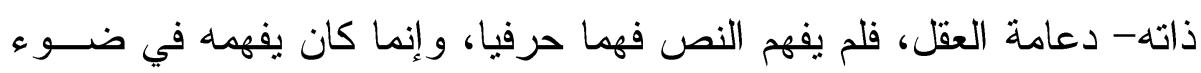

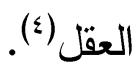

ورغم أنّه - أي الأشعري- حاول التوسط بين الـــص والعقـلـ(0) فــي

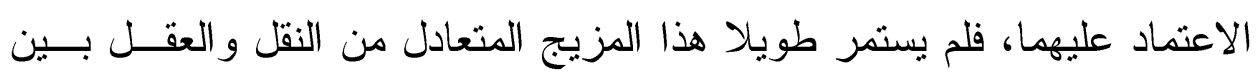

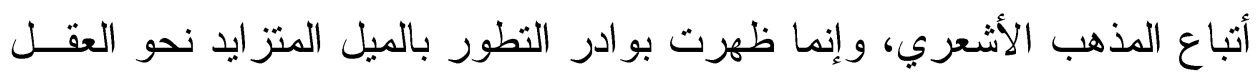

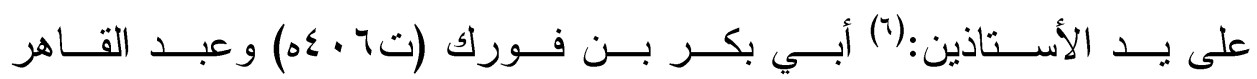
البغدادي(تو ؟عه)، فقد مال الأخير إلى جعل العقل أصلا للشرع، وذهب إلى أنّ

(') النشار، علي سامي. مناهج البحث عند مفكري الإسلام و اكتثاف المنهج العلمي في العـالم

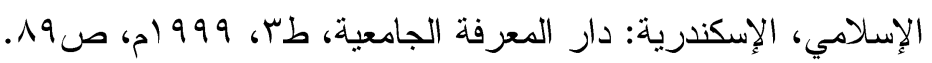

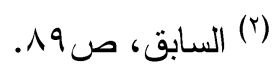

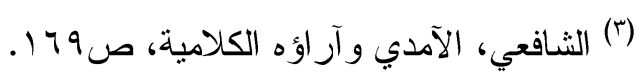

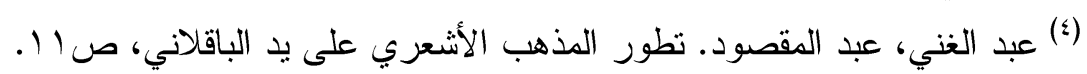

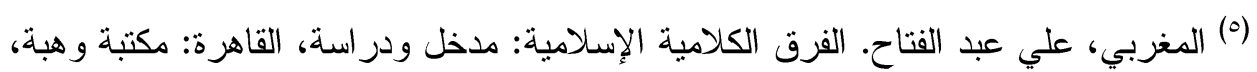

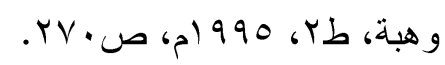

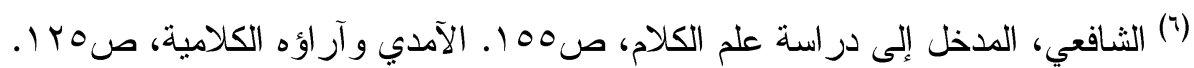


الصحة الثريعة مبنية على صحة النبوة، وصحة النبوة معلومة من طريق النظر

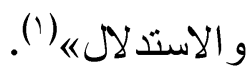

فلمّا جاء الجوينـي ذهب إلى أنّ ظواهر السمع (النقل) التي هي عرضـــة

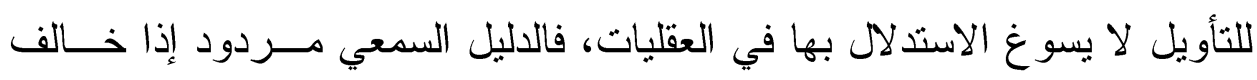

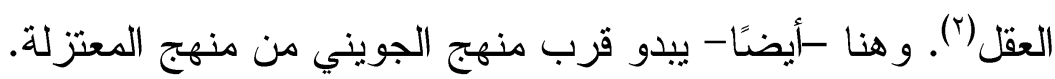

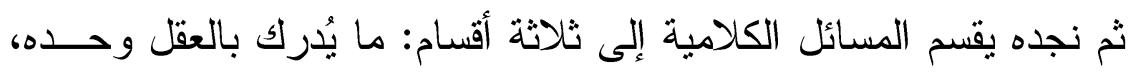
وما يُدرك بالسمع وحده، وما يدرك بهما معا. فيقول:»أصول العقائد تتقسم إلى ما يدرك عقلا، و لا يسوغ تقدير إدر اكه سمعا، و إلى ما يــدرك ســمعا، و لا يتة وــدر إدر اكه عقلا، و إلى ما يجوز إدر اكه سمعا و عقلاها"(r). لذا ألفيناه يدافع عن الأشعري و الباقلاني حينما استشهدا بأدلة سمعية على ولى إثبات وجود الله وبعض الصفات؛ مبينا أنّ استدلالهما بالسمع على هذه المسائل لم يكن على سبيل الاحتجاج المستقل؛ بل هو تعضيدٌ لأدلة السمع تيمنا(؛) أو مجــرد

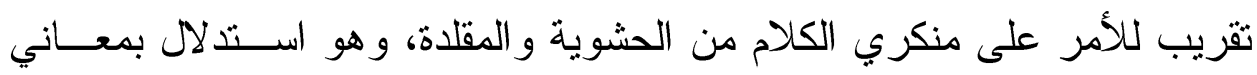
النصوص وليس بألفاظها(ث). كذلك، في مسألة إثبات الصفات، فإذا كان الأشــعري يثبـــ الصــــات

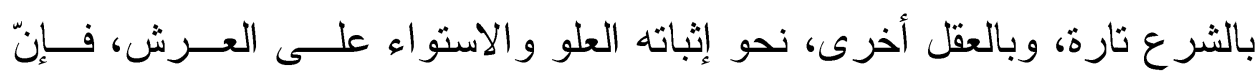
الجويني وأتباعه سلكوا طريقة المعتزلة فلم يثبتو ا الصفات إلا بالعقل (؟).

(1) البغدادي، أبو منصور عبد القاهر. أصول الدين، استتابول: نشرة مدرسة الإلهيـات بــدار

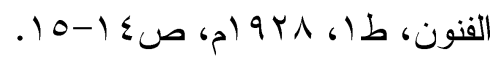

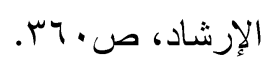

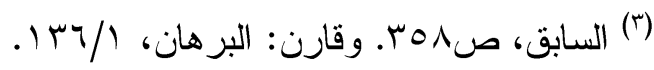

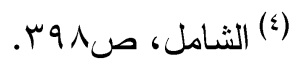

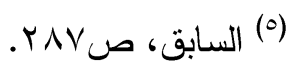

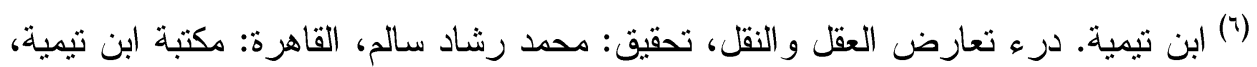

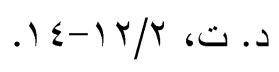


وفي الواقع، لقد ظهرت هذه الأفكار و الآراء التي بسطها الجويني مسبقا

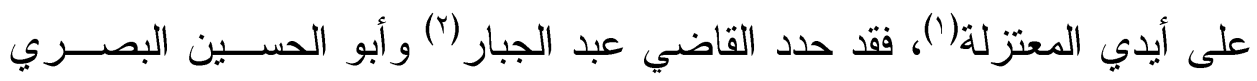
(ت (تسعه) العلاقة بين العقل و النقل، وما يُعلم بأدلة العقل وما يُعلم بأدلة الشرع،

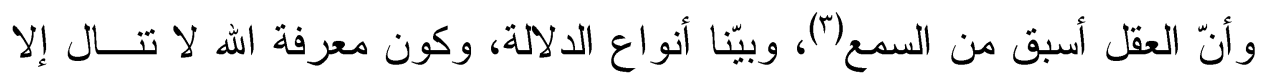

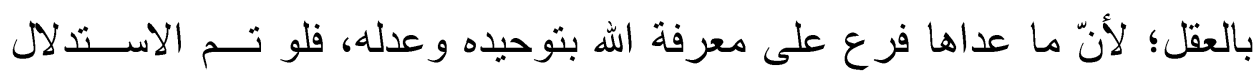

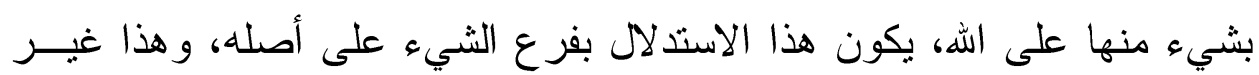

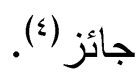

وذكر أبو الحسين البصري (ت بـعهـ) أنّ الأشياء المعلومة بالدليل إما

أن يصح أن تعلم بالعقل فقط، و إما بالشرع فقط، و إما بالشر ع و العقل معا(ث).

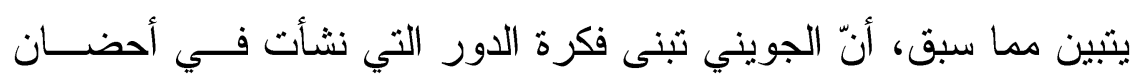

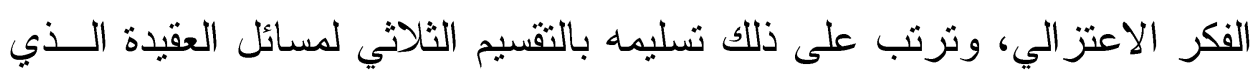

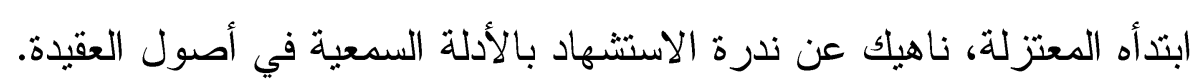

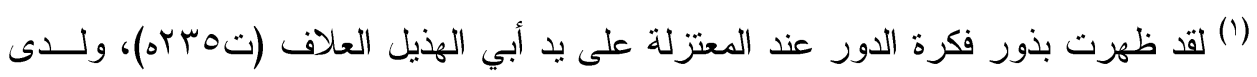

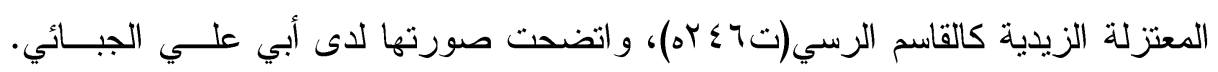

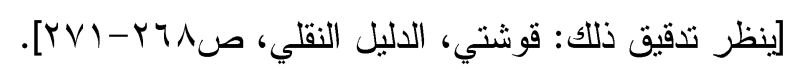

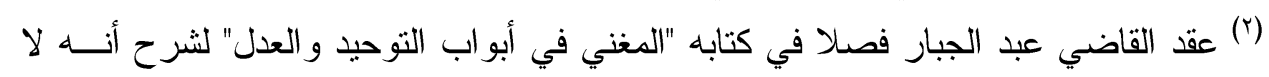

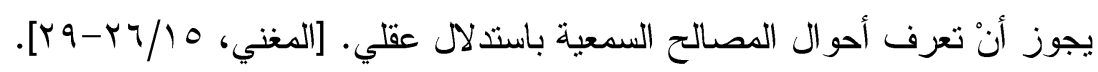

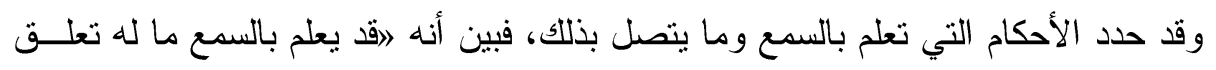

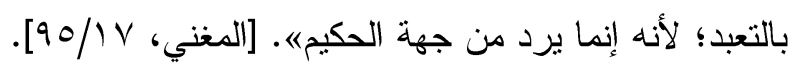

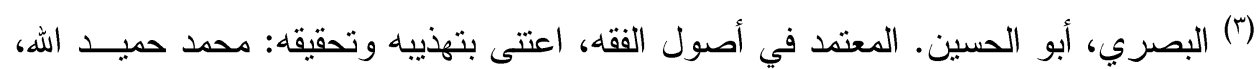

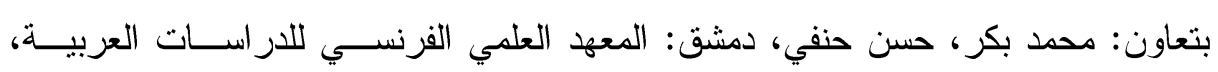

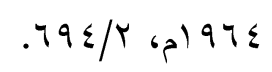

(؛) القاضي عبد الجبار، شرح الأصول الخمسة، حققه وقدم له: عبد الكريم عثـــان، الهيئــة

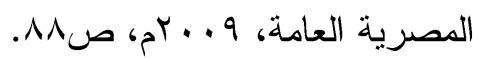

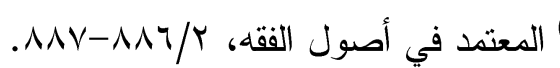


(ب) وفي إثبات الصفات للصانع، فإنّ الجويني يستعمل قيــاس الغائسـب عنــى

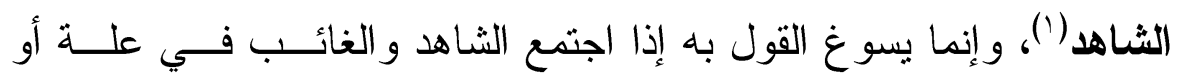

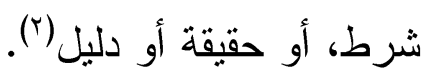

فإثبات 》العلم بالصفة الأزلية لا يُتلقى إلا من اعتبار الغائب بالثاهده("َ)،

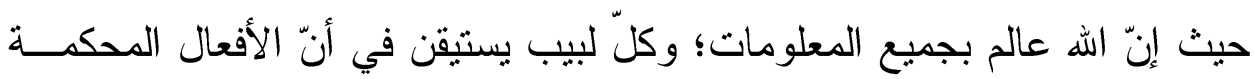
المتقنة الو اقعة على أحسن ترتيب ونظام لا تصدر إلا من عالم بها، أما من جوّز صدور خط منظوم على ترتيب معلوم من غير عالم بالخط، كان مــن المعقــول

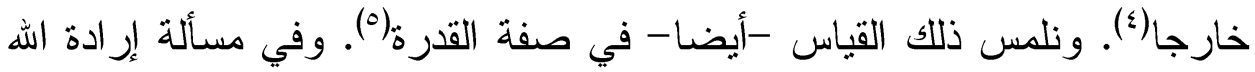

و إر ادة العبد (־).

و هذا الاتجاه لا يختلف عمّا صنعه المعتزلة من ذي قبل، فالقاضي عبـــ

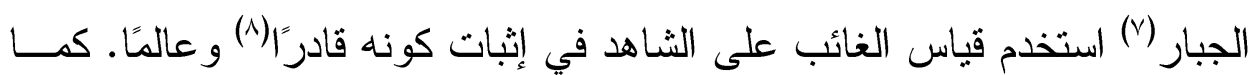
استخدمه -أيضا- في إثبات صفة الحياة(9).

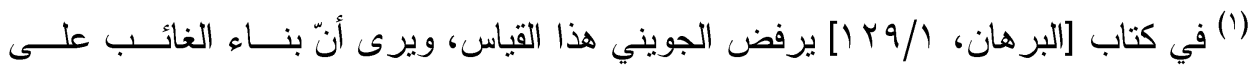

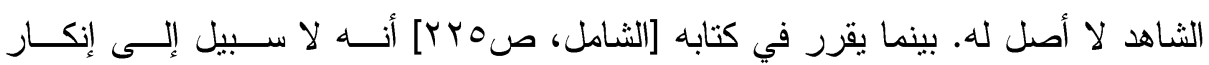

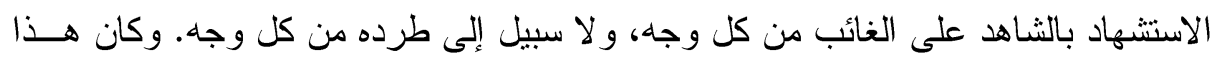
التزدد أيضا لدى الباقلاني فتارة بعمل بهذا القياس، وتارة برفضه.

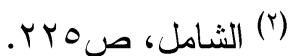

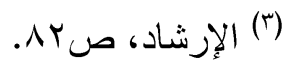

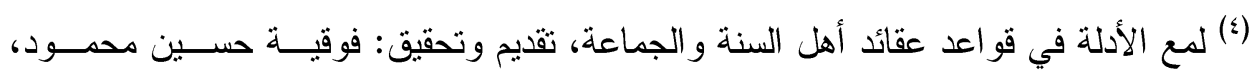

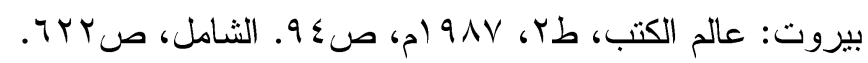

$$
\begin{aligned}
& \text { (0) لمع الأدلة، صع } 9 .
\end{aligned}
$$

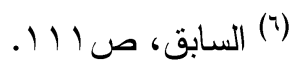

(v) القاضي عبد الجبار، المحيط بالتكليف، جمع الحسن بن منوية، تحقيق: عمر السيد عزمي،

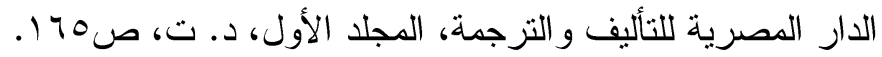

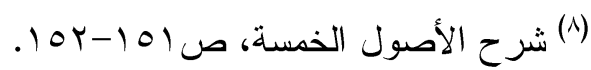

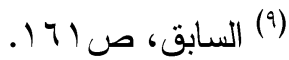


فيستدل على صفة كونه عالما بقوله: اوجدنا في الشاهد قادرين: أحدهما قد صح منه الفعل المحكم كالكاتب، والآخر تعذر عليه كالأمي، فمن صـح منـــه

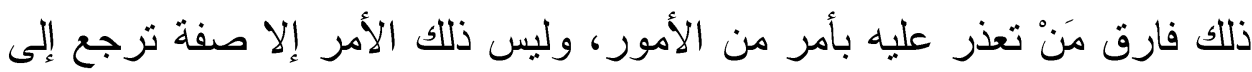

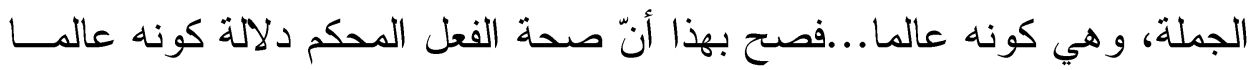
في الشاهد، و إذا ثبت ذلك في الثاهد ثبت في الغائب؛ لأنّ طرق الأدلة لا تختلف غائبا وشاهداه (')

كما أنّ المعتزلة أخذوا بهذا القياس فيما يتعلق بأفعال اله تعالى، فقــالوا

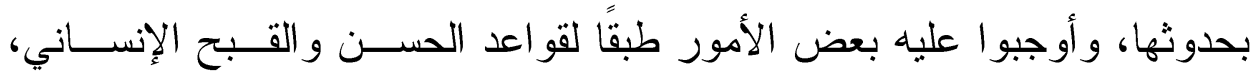
وقياسًا على حال الإنسان(؟). كذلك، وظف أبو رشيد النيسابوري هذا القياس فـي الإني الدلالة على وجود القديم("). ولمعترضٍ على هذا القياس أنْ يقول: ما هي الضــرورة التـي دعـــ

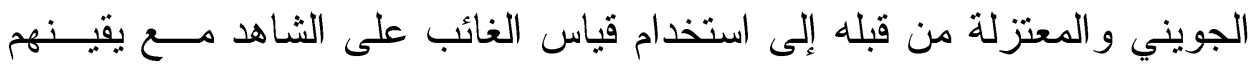
بالفو ارق بين عالم الغيب و عالم الثهادة؟ تتلخص الإجابة عن هذا التساؤل في كون الإنسان لا يستطيع الانفكـاك عن الاعتبار ات الإنسانية، ثم لابدّ له من النظر في أمسـور مـــا بعــــ الطبيعــة

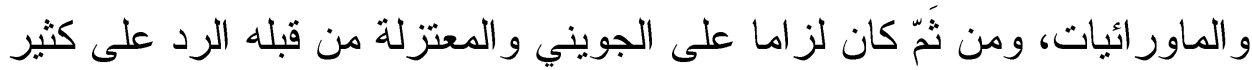
من الفرق و النحل، التي تمتلك تعقيدات فلسفية، لذا فالوقوف عند النص وحده لا يقنع سوى العامة، أما الخاصة و أصحاب الفرق التي تسلحت بالمنطق فهي تجادل بالعقل، و استخدام العقل في الدين يجعل الدين قضايا منطقةـــة ومســائل عقليـــة

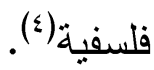

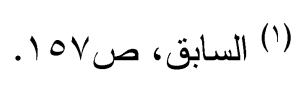

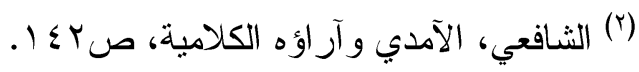

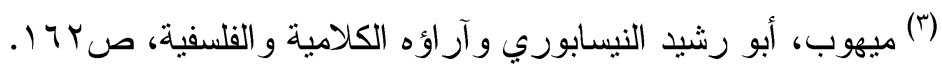

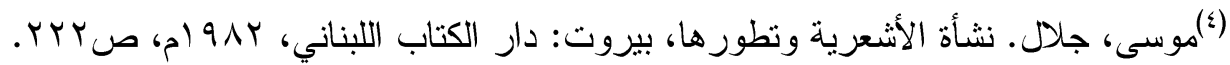


(د) النقل عند الجويني يُرشد إلى ما لا يُستّرك بمحض العقول، و لا يــرد بــــا يقضي العقل بخلافه؛ لأنّ حجج الله تتعاضد ولا تتعارض، فلا يتصور ورود

دليل سمعي قطعي مخالف لقضية العقل (1).

\section{ثالثا_النزعة النقدية:}

- النقد الأتي (المذهبي) عند الجويني:

في هذه الحالة يحاول المتكلم أنْ يبقى وفيا لمدرسته، لكنه يــدرك -فئي

الوقت ذاتهـ قصور المو اقف التقليدية، فيقتــر ح مـــا يمكـن اعتبــاره تجـــاوزا

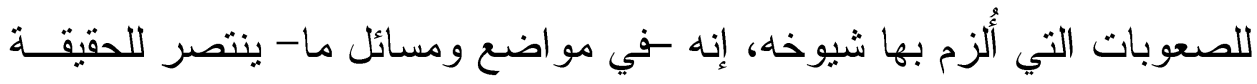

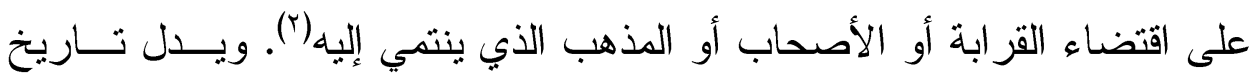
التفكير الديني و الفلسفي على أنّ أتباع المذهب الواحد لا تتطابق آراؤهم دائمــا، و لا يتفق بعضهم مع بعض تمام الاتفاق، وكثيرًا مـــا يخــالف التلاميـــ تعــاليم

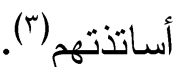
و الاليل على ذلك ما نلحظه في تفكير مدرسة المعتزلة، فقد ســلك أبــو

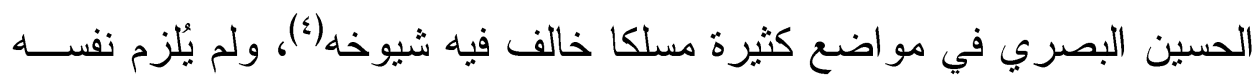

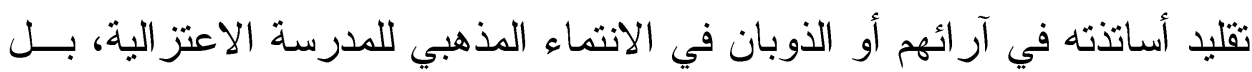
كان ينتخب من المو اقف و الرؤى السابقة عليه ما ينسجم مع قناعاته، وهو فـي مقالاته يرد على شيوخه من المعتزلة بتصفح أدلتهم ونقضهان(ه).

$$
\text { (') (1) (الإرشاد، ص. (1) }
$$

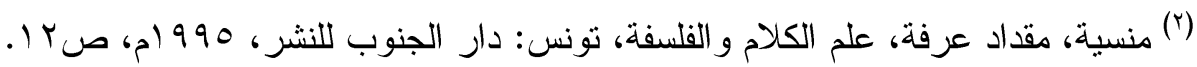

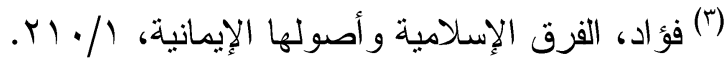

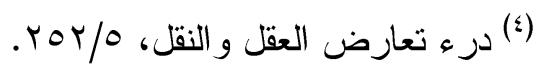

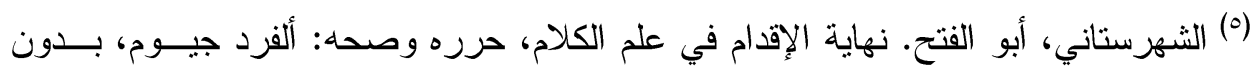

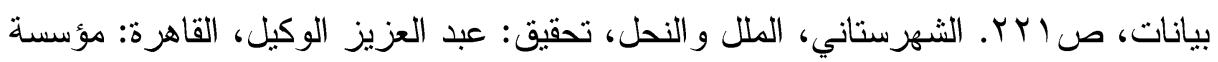

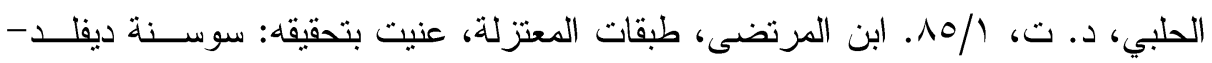

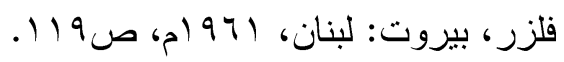


بيد أنّ هذا الاختلاف مع السابقين عليه من المعتزلة لم يكن هدفه تقويض المذهب و هدمه رأسا على عقب، بل سد ثغر ات المذهب وتثبيت أركانه في وجه الخصوم و المخالفين.

ومن الملفتِ للنظر أنّ هذا الموقف النقدي كان حقا مكفو لا ـإن جاز هذا

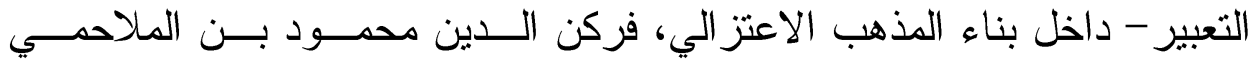

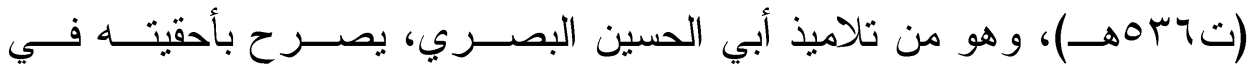
الاختلاف مع أستاذه(1)، فيقول:انذكر مع هذا ما يخالف فيه اختيارنا لما يختــاره الشيخ أبو الحسين رحمه الله، وإن كان يقل ذلكهاء (؟). ولم يخرج تقي الدين النجراني (توفي في القرن السابع الهجري) عن هذا

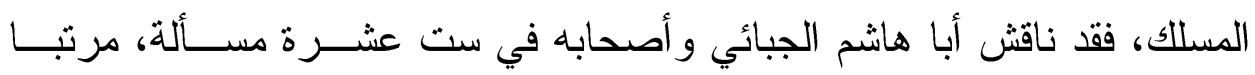
الاعتر اضات عليها، ومنبها على مو اضع الغلط، فقي \بعضها وقع الخلاف فـي حكم المسألة، وفي بعضها إن وقع الوفاق في حكم المسألة، لكن وقع الخلاف في طريق إثبات ذلك الحكمه(") يتبين من هذا، أنّ مذهب المعتزلة من المذاهب الفكرية المرنـــة، التــي

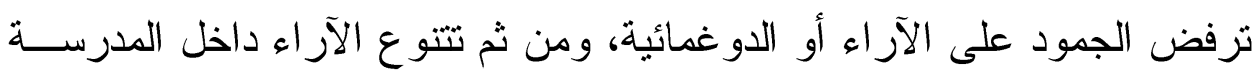

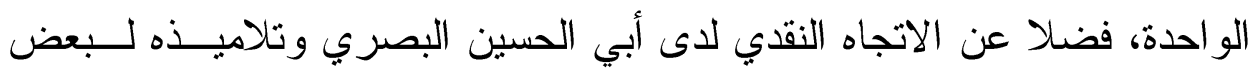

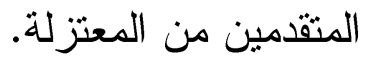
وقد بدا هذا الاتجاه النقدي (الذاتي) عند إمام الحرمين الجويني جليا فـي مو اضع متعددة من مؤلفاته، وذلك على النحو التالي:

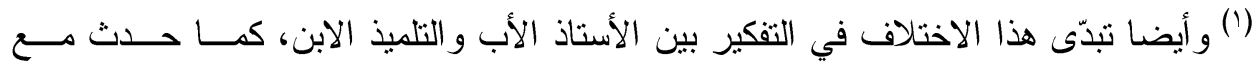
الجبائيين: أبي علي و أبي هاشم في مسألة (الأحوال).

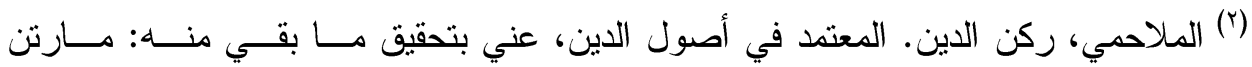

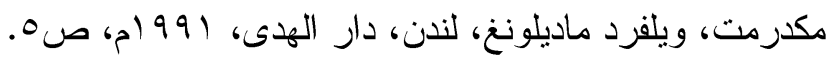

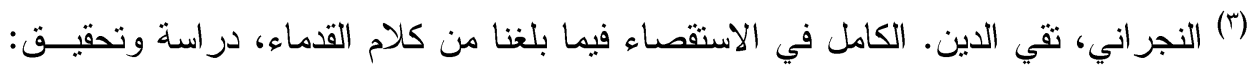

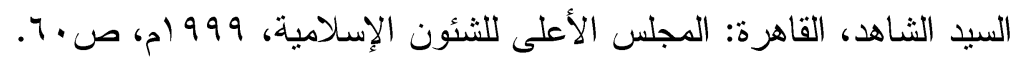


(أولا) خالف الجويني شيخه أبا الحسن الأشعري في مسائل كلامية، وذلك رغــم

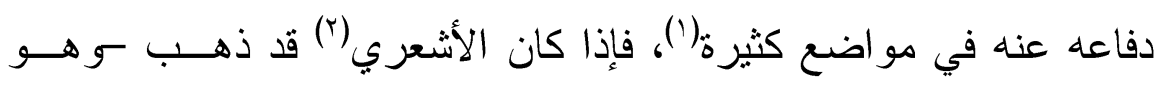
بصدد مسألة الأفعال الإلهية و الإنسانية- إلى القول بنظرية الكسب مجردا القدرة الإنسانية من كل فعل لها، ذاهبا إلى أنّ الهه هو الفاعل المطلق، وأنّ الإنه فعل العبد خلق لله إبداعا وكسبا للعبد، فإنّ الجويني اقترب في هذه الناحية

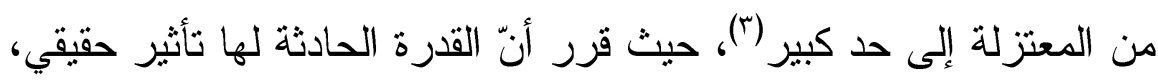

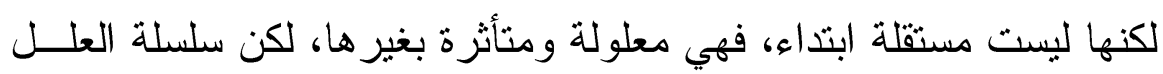

$$
\text { و المعلو لات تتتهي إلى مسبب الأسباب(ء). }
$$

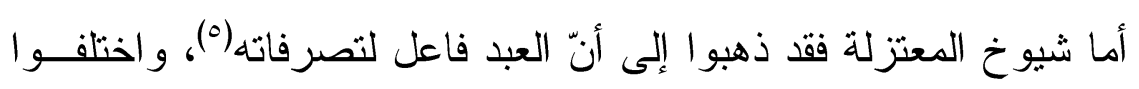

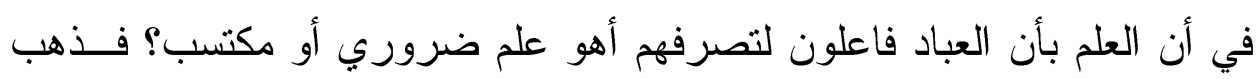
أبو علي وأبو هاشم الجبائبان وأصحابهها إلى أنّ العلم بذلك مكتسب، بينما ذهب إنب أبو الحسين البصري وركن الدين الملاحمي إلى أنّ العلم بذلك ضروري(ّ). و أبو الحسين البصري يقول مع ذلك:إإن الفعل يتوقف على الـــداعي والقــدرة، و عندهما يجب الفعل، وهو حقيقة قول أهل الإثبات، ولهذا يعبر غير واحد مــنهم

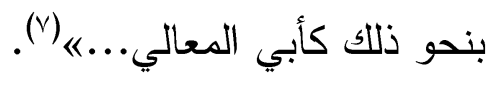

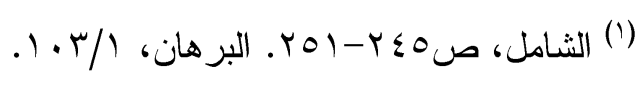

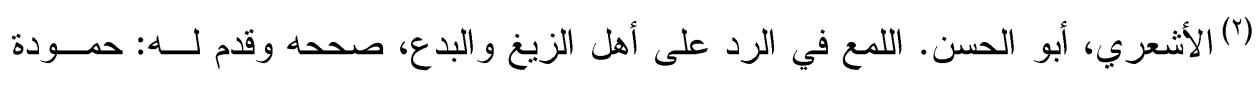

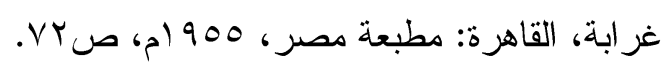

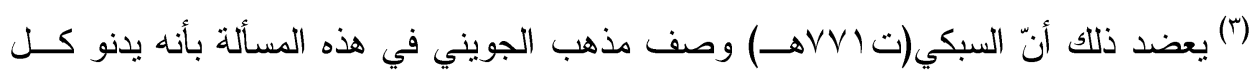

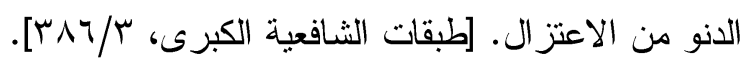

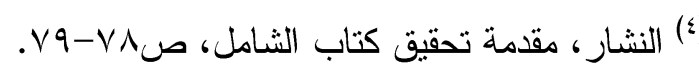

(•) الملاحمي، ركن الدين. الفائق في أصول الدين، حققه وقدم لله: فيصل بدير عون، القاهرة:

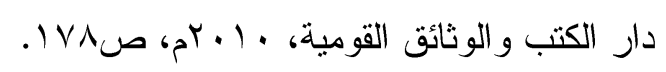

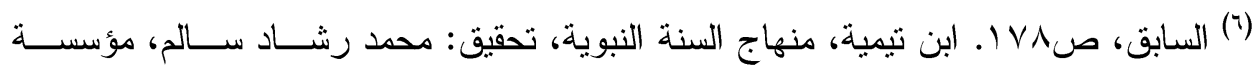

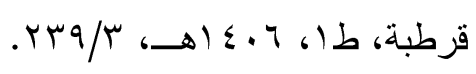

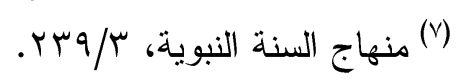


ثم يستدلون على أن العباد محدثون لأفعالهم بأنهم يعلمون ضرورة حسن

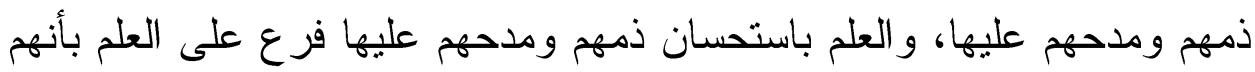

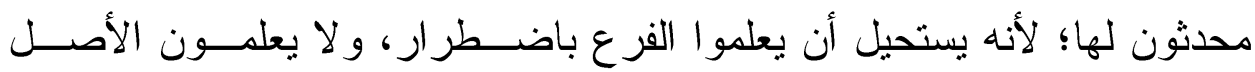

باضطر ار (') (1)

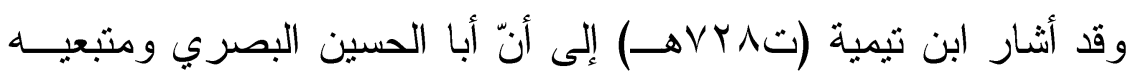
في القدر يقولون:»إن العبد فاعل لفعله حقيقة، ومحدث لفعله، والله سبحانه جعله فاعلا له محدثا له. و هذا قول جماهير أهل السنة من جميع الطو ائف، وهو قــول كثير من أصحاب الأشعري كأبي إسحاق الإسفر اييني و أبي المعـالي الجــويني الملقب بإمام الحرمين و غير هماه( (؟). ولعل هذا يدفعنا إلى بيان موقف الجويني من الأفعال الإنسانية وصــــلتها

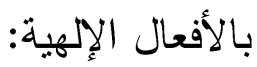
لقد كان للجويني رأيان في هذه المسألة: الأول: صر ح به في كتابه "الإرشاد"، إذ يرى أنّ القدرة الحادثـــة لا تــؤثر فــي

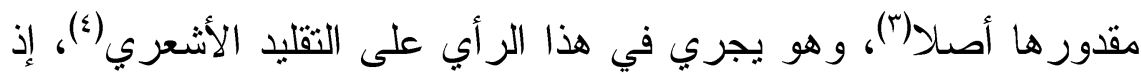

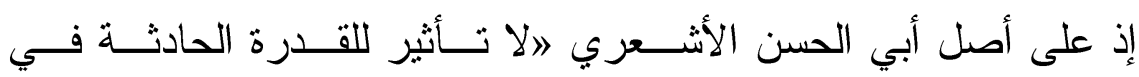
الإحداث

والثاني: صر ح به في كتابه "العقيدة النظامية"، فذهب إلى ثأثثر القدرة الحادثة في إيجاد الفعل؛ إذ إنّ الفعل يقع بتأثير القدرة الإنسانية وحـــها التــي هـي مخلوقة لله تعالى بعد توفر دو اعيه و أسبابه.

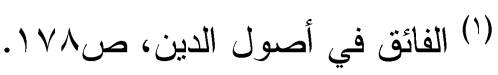

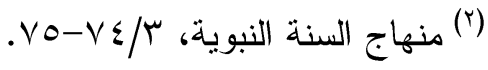

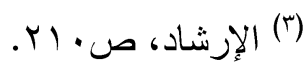

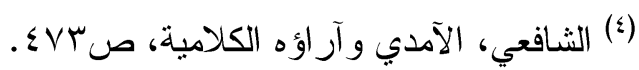

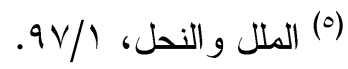


ثم يستّل على هذا الرأي بأمور منها:

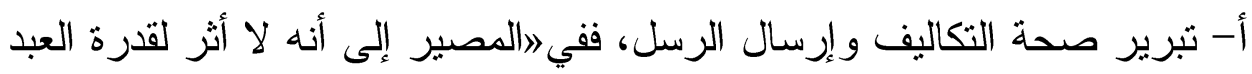

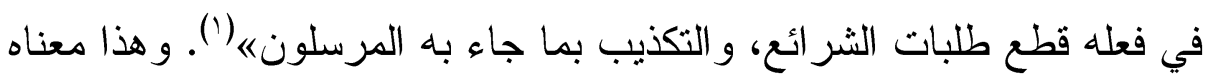

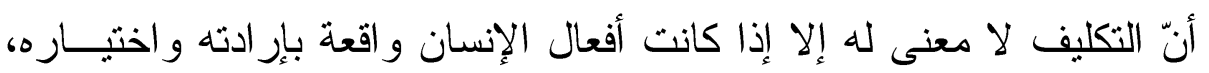

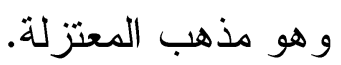

ب- يعد نفي تأثثر القدرة الحادثة في مقدور ها مخالفا للحس و العقل، إذ يقول:»أما

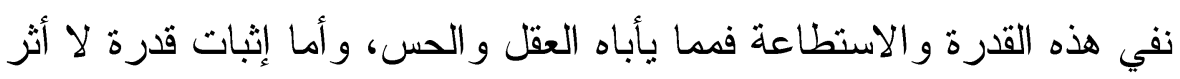

$$
\text { لها بوجه، فهو كنفي القدرة أصلاه(؟). }
$$

و لا يكاد يختلف رأي الجويني عن المعتزلة إلا في تسميته ذلك كســبـا لا

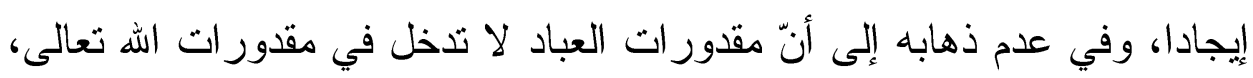
بل هي عنده مقدورة لله مخلوقة له بحكم خلقه للعبد وقدرثه الحادثة (").

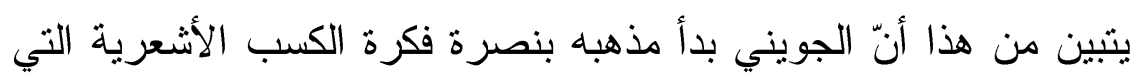

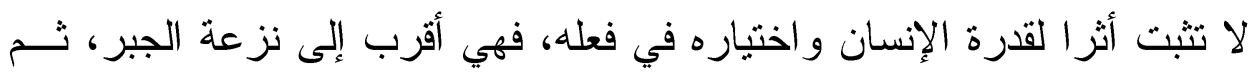

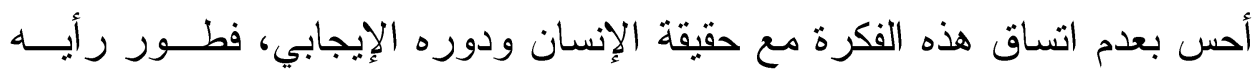

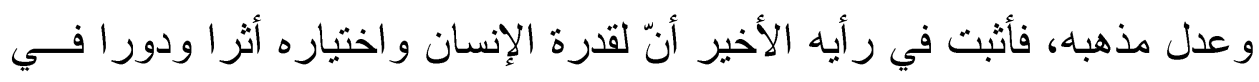
الفعل، فهي قدرة حقيقية لا وهمية (؛) فئ.

(') العقيدة النظامية في الأركان الإسلامية، تحقيق: محمد زاهد الكــوثري، القـاهرة: مكتبــة

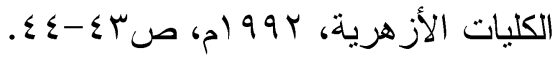

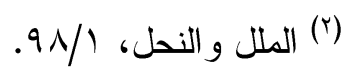

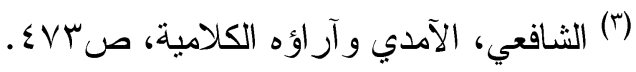

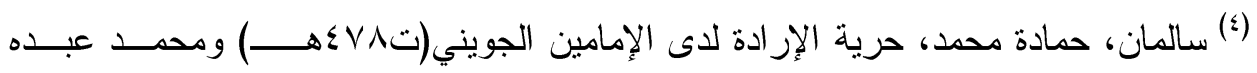

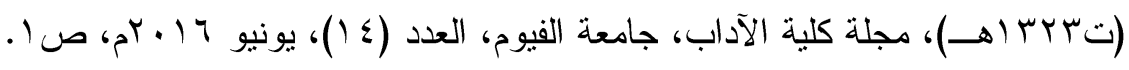


وكان هذا التطور الذي أبداه الجويني (') بمثابة تحول عن النزعة الجبرية،

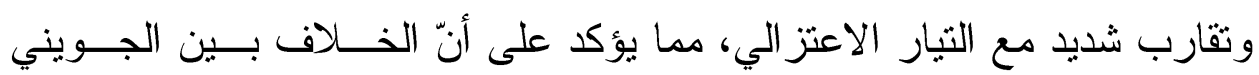
و المعتزلة -في هذه المسألة- كان منحصر ا في دائرة الألفاظ دون المعاني. (ثانيا) على الرغم من تقدير الجويني لآر اء شيخه الأشعري، فإنه ضعَف التأويل المشهور له لبعض الصفات الفعلية مثل: الاستو اء و النزول و المجيء من هن

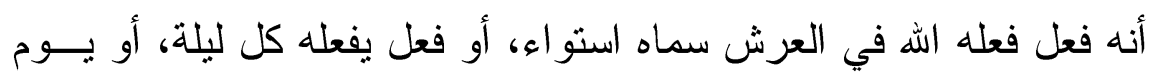

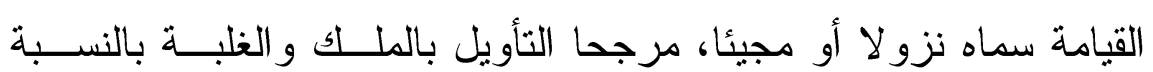
للاستو اء، وبنزول أو مجيء أمره أو بعض ملائكته(باه.

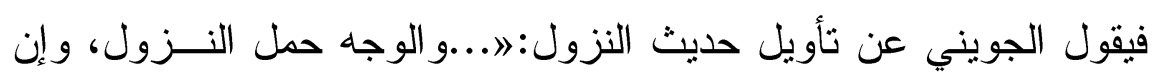

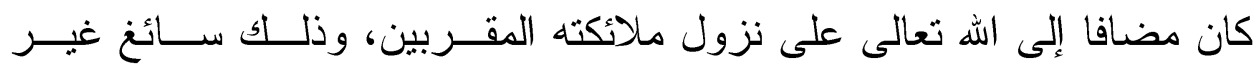

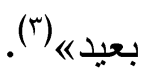

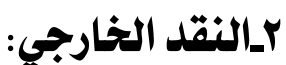

لا يستطيع مفكر منصف أنْ ينكر أنّ المواقف النقدية للمعتزلة قد ألقـــ

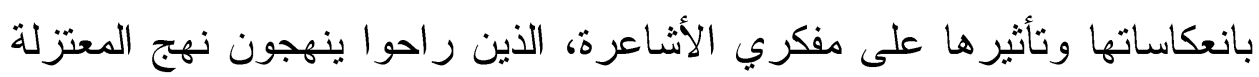
ومسلكهم في الرد على الخصوم وتفنيد مذاهب المخالفين ونقدها(ئان.

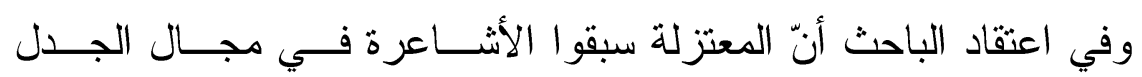
و المناظرة و إفحام الخصوم و التفنيد و النقد لآر اء المخالفين ومذاهبهم، سواء أكان النئ

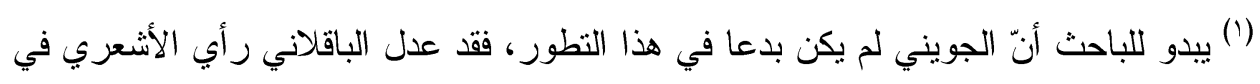

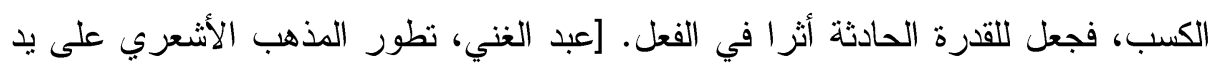

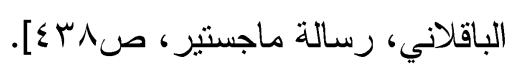

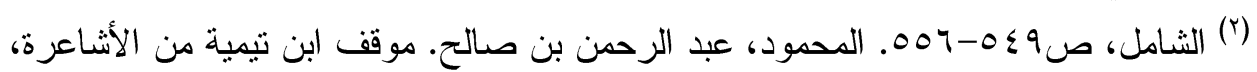

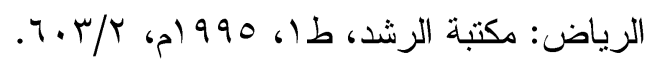

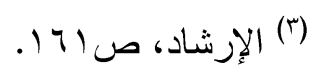

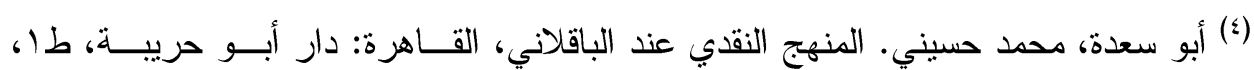

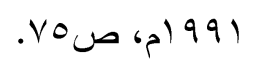


المخالفون من أصحاب الفرق الإسلامية أم من أصحاب الملل و الديانات و النحـلـل الأخرى("). ولعلّ الذي دفع المعتزلة إلى ذلك، هو الدفاع عن العقبدة الإســلامية الإسية

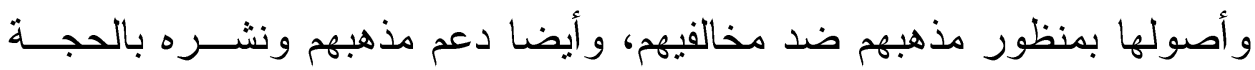
و البرهان، و الكثف عما يعتور مذاهب الخصوم و المخالفين من ثغرات(؟).

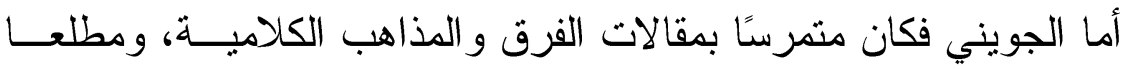

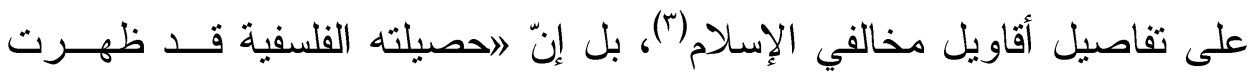
وتبلورت في ردوده على خصومه من المناوئين للمذهبه(أ) الأشعري. فأبطـلـل قول الدهريّ بأنّ الحوادث لا أول لها(ْ)، ور أى استحالة أنْ يكون مُخصص العالم - أي صانعه وموجده- طبيعة، كما صار إليه الطبائعيون(؟).

(') لليس من المبالغة أن نقول: كانت مهمة الرد على المخالفين و النقض و المعارضـــة لأدلــتهم

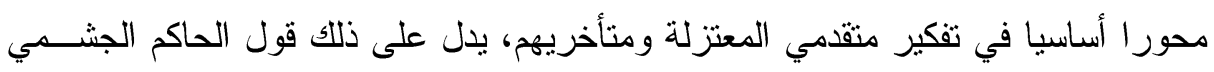

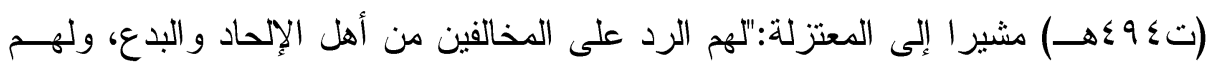
المقامات الششهورة في الذب عن الإسلام". [الحاكم الجشمي، من عيون المسائل، ص الوبـ].

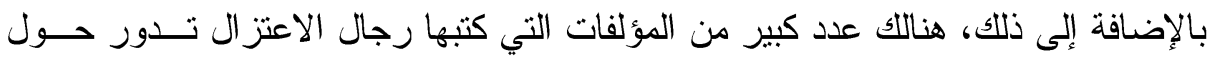

$$
\text { مجابهة المخالفين والرد على أدلتهم بالحجاج العقلي. }
$$

ومثال ذلك: أن من المهام التي كلف بها أبو الحسين البصري نفســهـ أعمــال المعارضـــة و الخصوم، فقام بالرد على معارضيه، يظهر ذلك من خلال نقوضه لآر اء الثيعة الإماميــة

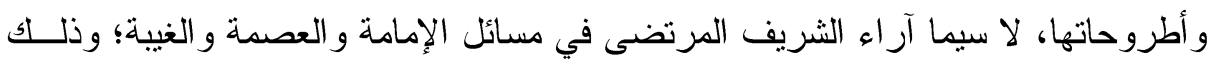
من خلال كتابيه (نقض الثافي في الإمامة-ونقض المقنع في الغيبة).

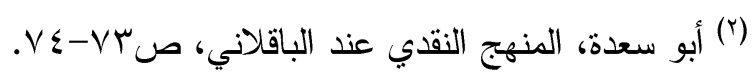

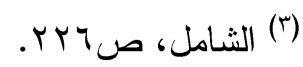

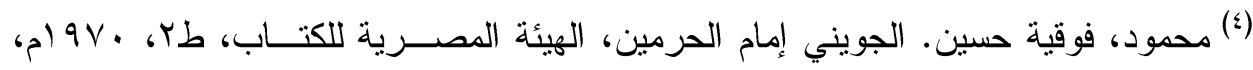
ص1.07

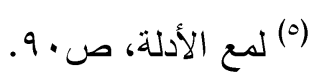

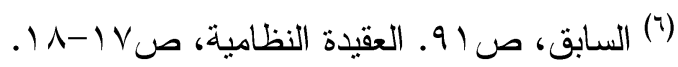


وذكر الجويني اتفاق أهل الملل و النحل على أنّ الرب يتقدس عن قبـــــ

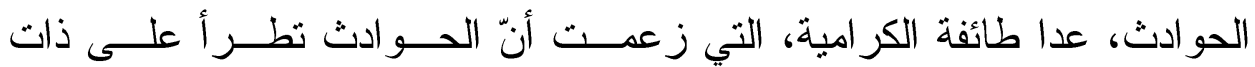

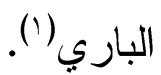

ثم يشرع في الرد عليهم و اصفًا مقالتهم بأنها مذهب المجــوس، فالـــليل على استحالة قيام الحوادث بذات الباري، أنها لو قامت به، لم يخل عنها، وما لم

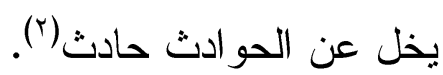
وفي مو اضع كثيرة من مؤلفاته يظهر الجويني انتقادات حـــادة لأفكــار

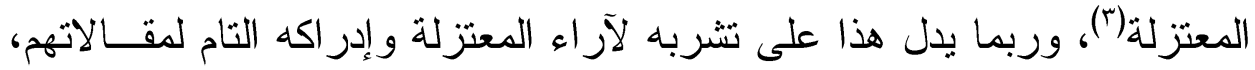

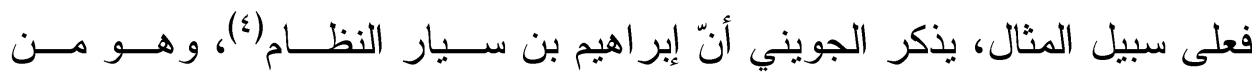

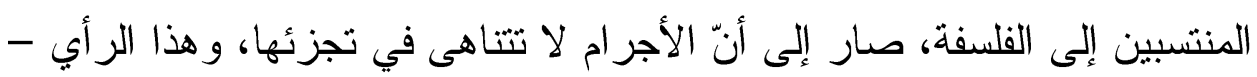
كما يذكر الجويني - يؤدي إلى هدم قو اعد الدين(0).

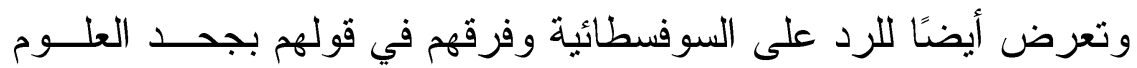

و إنكار ها(`).

$$
\begin{aligned}
& \text { (1) لمع الأدلة، ص9.1. } \\
& \text { (ץ) السابق، ص99 ـ 1. }
\end{aligned}
$$

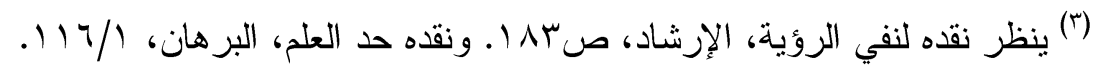

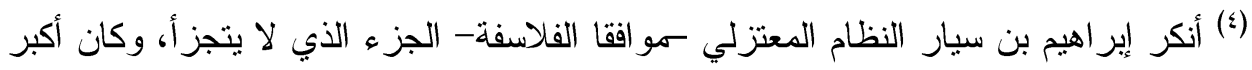

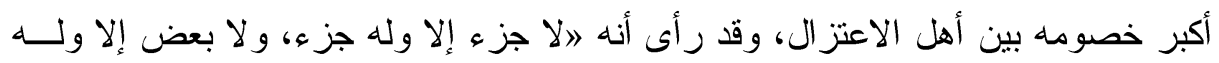

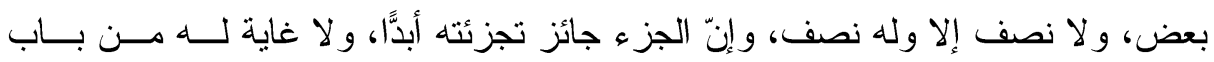

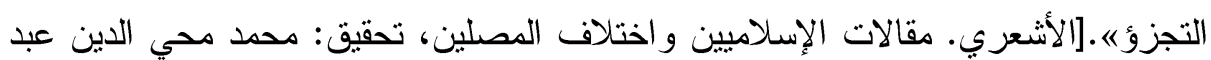

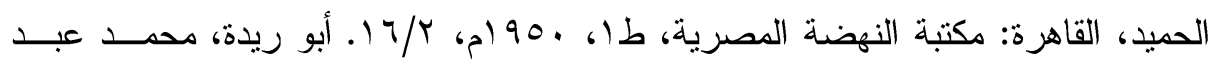

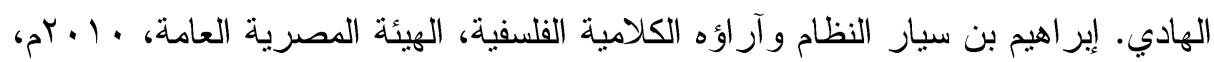

$$
\begin{aligned}
& \text { صar ו-. r II]. }
\end{aligned}
$$

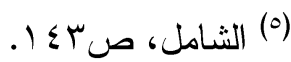

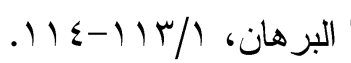


أما الحشوية المنتمون إلى الظاهر فيرون أنّ الكلام القــديم يحـلـ فــي الأجسام و لا يفارق الذات، وفي هذا -كما يذكر الجويني - مضاهاة لنص مـــهب

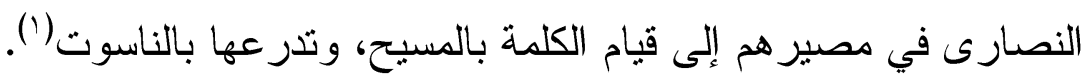

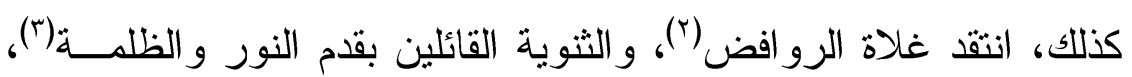
وطو ائف من الباطنية، في قولهم: لا يثبت للباري صفة من صفات الإثبات(؛).

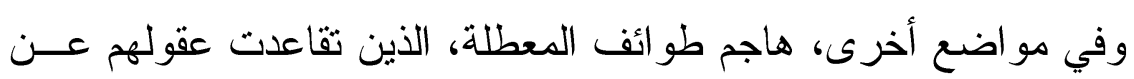

درك حقيقة الإله (0).

\section{رابعًا_الاتجاه الفلسفي عند الجويني:}

يبدو للقارئ لمقو لات الجويني و أفكاره أنه أفاد من فلسفة اليونان مقــدرة على الجدل، وقوة في الاستدلال والاحتجاج، وذلك على الرغم من أنه لم يشتغل

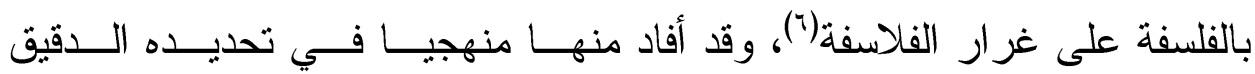
للمصطلحات الكلامية و الفلسفية، وكذا في تقديمه للنظريات الكلامية بأبحاث فـي وني وني

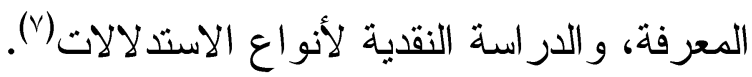

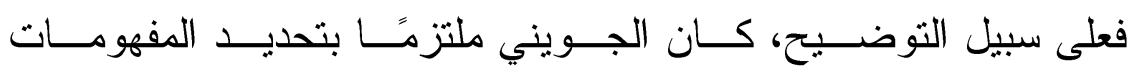
و المصطلحات قبل الخوض في المسائل التي يبحثها، وهذا التحديد هـــو بمثابــة المقدمات أو الفروض المؤدية إلى النتائج، لذا يمكن القول بأنّ منهجه في مســألة

$$
\begin{aligned}
& \text { (') الإزشاد، ص. •"1. }
\end{aligned}
$$

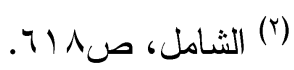

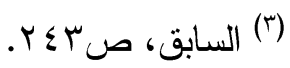

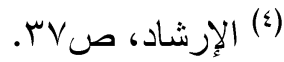

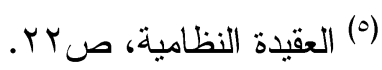

(†) وهذا أمر طبيعي، فلم يكن هدفه أن يكون فيلسوفا بكل ما تحمله اللفظة من قسمات، وإنمــا

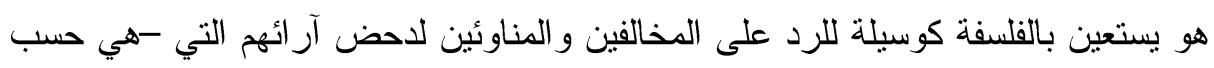

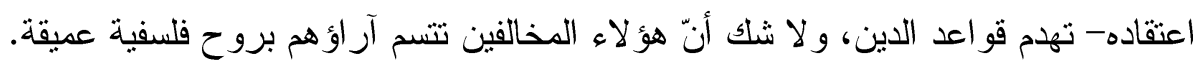

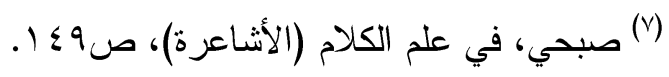


(حدوث العالم) منهج قياسي يضـع المقدمات أولا، و الحدود ثانيــا، ليصــل إلــى

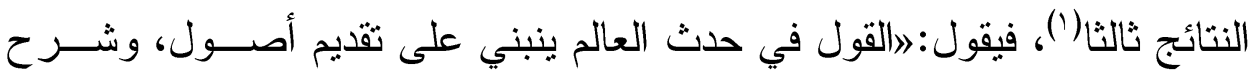

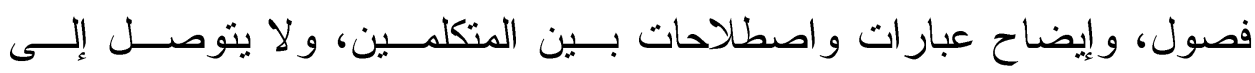

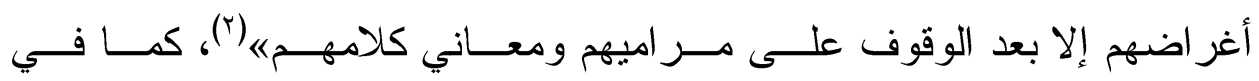
مصطلحات:() العالم، و الجوهر و العرض، و والقديم و الحادث....إلخ.

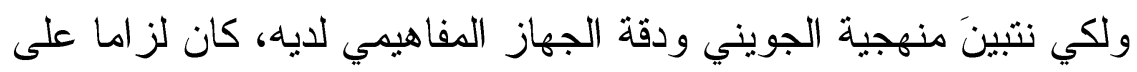
الباحث أن يشير إلى قضية المصطلحات Terminology؛ لأنّ اللغة استدلال مؤدٍ إلى المعرفة، وهي -في الوقت نفسه- صيخ تؤدي إلــى بُنـى أساســية نعبــر بو اسطنها إلى الحقيقة(£). فمعرفة معاني المصطلحات وما تواطأ عليه أهل كل فن من الفنون أمر ضروري للغاية، يؤكد هذا ما نلحظه من عناية الجويني بالمصطلحات(0): تفسيرًا

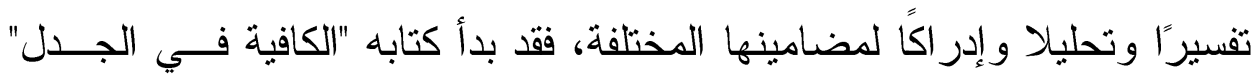
ببيان أهم المصطلحات ومعانيها؛ حسمًا لأي خلافٍ قد ينتج عن غموض مدلول الألفاظ فيقول:»لا يتم تحقيق النظر لمن لا يكون مستوفيَّا لمعاني ما يجري مــن

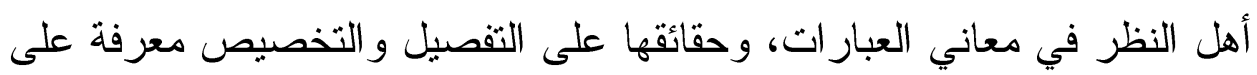

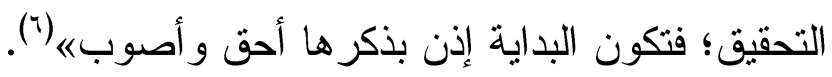

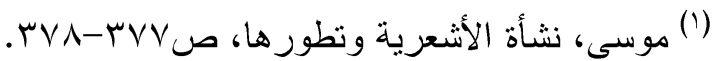

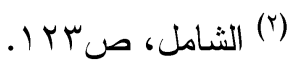

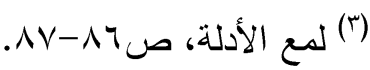

(؛) دغيم، سميح. موسوعة مصطلحات علم الكلام الإسلامي، مكتبة لبنان ناشرون، بيــروت،

$$
\text { طا، 19919 ام، المقدمة. }
$$

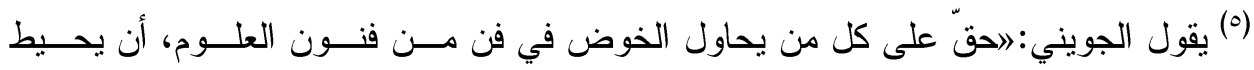

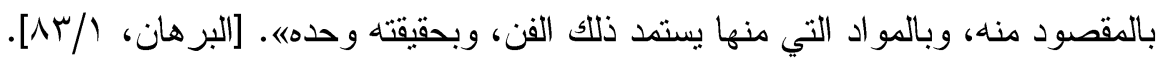

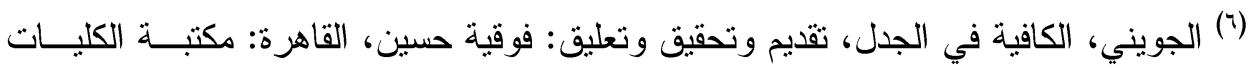

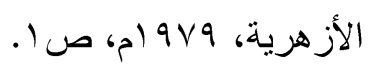


وتبدو -أيضًا- عناصر ثقافته الفلسفية في ردوده علــى الفلاسـفة مــن طبائعيين و غيره، فكتابه (الشامل في أصول الدين) خير مثال في إثبــات تــــفر

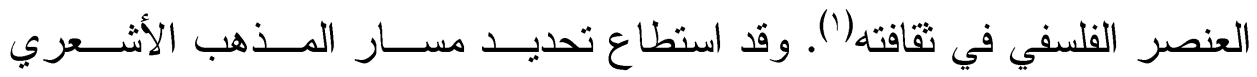

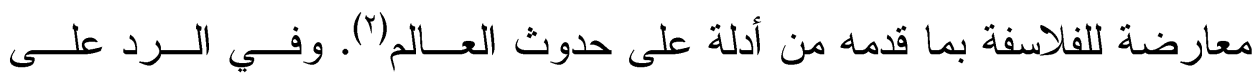
الفلاسفة القائلين بقدم العنصر و الهيولى (ّ). وقد رأى الجويني استحالة أن يكون مخصص العالم وصانعه علة موجبة

كما صار إلبه الأوائل، و إنما هو صانع مختار، موصوف بالاختبار و الاقتدار (؛).

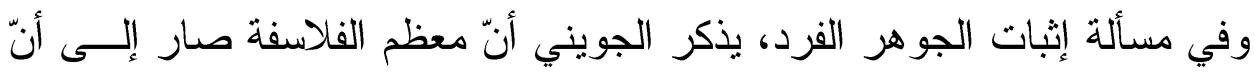
الأجر ام لا تتتاهى في تجزئها(م)، ثم يشرع في الرد على هؤلاء الفلاسفة، القائلين

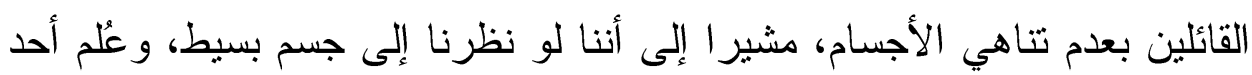

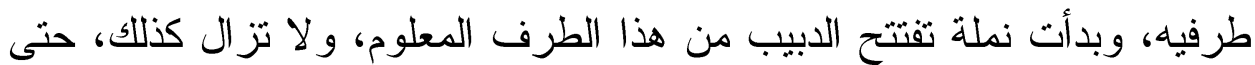
تتنهي إلى الطرف الآخر، فهذا يعني أنها قطعت الجسم، فلو كانت أجزاؤه غبــر متتاهية، لما تصور الفراغ من قطعه وتخليفه؛ إذ الانقضاء ينبئ عن الانتهــاء، وما استحال عليه وصف الانتهاء، لم يُعقل فيه الانقضاء(؟).

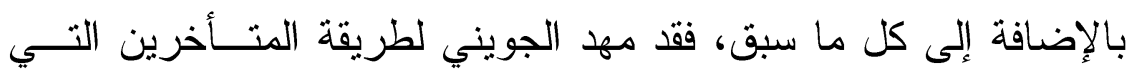
خلطت بين علم الكلام و الفلسفة(V).

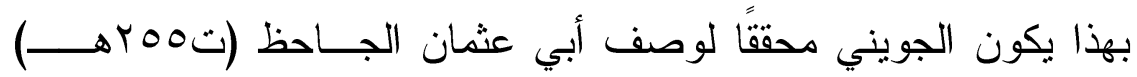
للمتكلم الجيد بأنه الذي يُحسن الجمع بين الدين و الفلسفة، فيقول:》لــيس يكــون

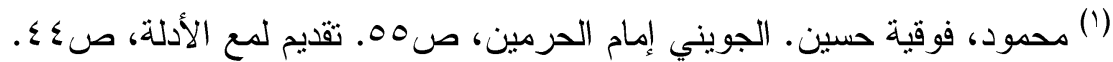

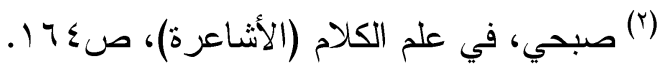

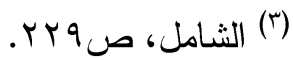

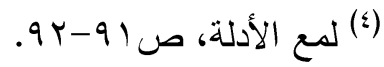

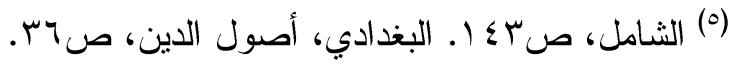

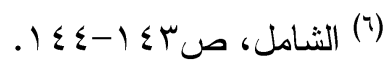

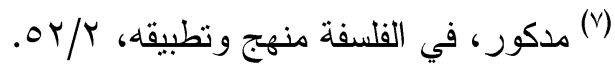


المتكلم جامعًا لأقطار الكلام، متمكنًا في الصناعة، يصلح للرياسة حتـى يكـون الذي يحسن من كلام الدين في وزن الذي يُحسن من كلام الفلسفةه(").

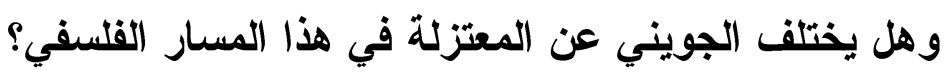

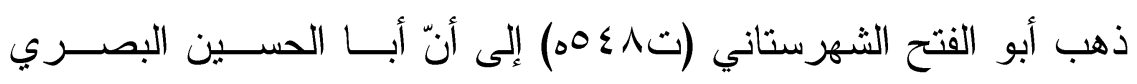
فلسفي المذهب(r)، ينهج في جميع مقالاته مناهج الفلاسفة(r)، فقد أوجد خطا جدليا جدليا بين الاعتز ال و الفلسفة، كمحاولة حقيقية في الثورة على النمطية و الاتباعية

المذهبية، ومبادرة لتأسيس الأصول الاعتز الية وفق رؤيته الفلسفية(؛).

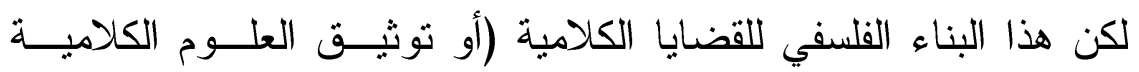

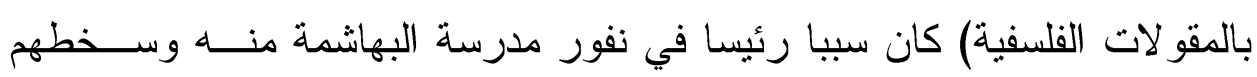

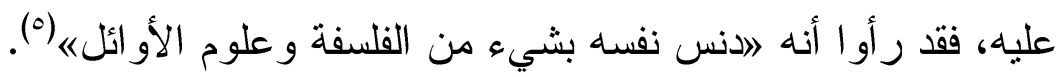
وأيضا كان ركن الدين بن الملاحمي على وعي تام بمصطلحات الفلاسفة

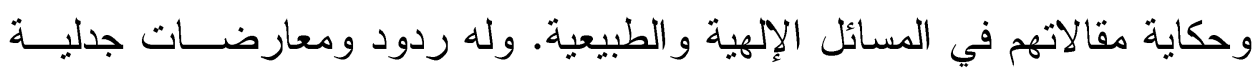
للفلاسفة كما في كتابه "تحفة المتكمين في الرد على الفلاسفة"(؟).

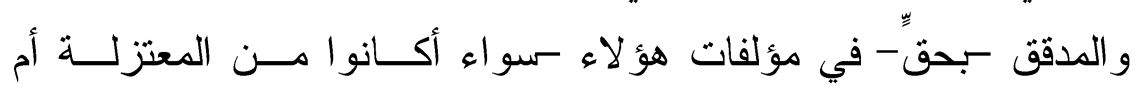
الأشاعرة- يجد أنهح لم يققو عند حد ثقرير العقائد الدينية وإثباتها بالأدلة العقلية،

(1) الجاحظ، أبو عثمان. الحيوان، تحقيق: عبد السلام هارون، القاهرة: مكتبة مصطفى البـابي

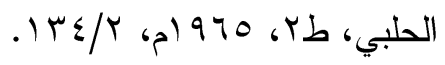

$$
\begin{aligned}
& \text { (r) الملل و النحل، 10/1) }
\end{aligned}
$$

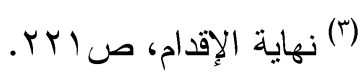

()) الراوي، عبد الستار. العقل و الحرية في فكر القاضي عبد الجبــار المعتزلــي، بيــروت:

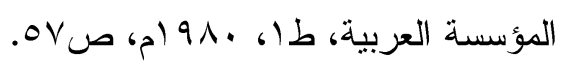

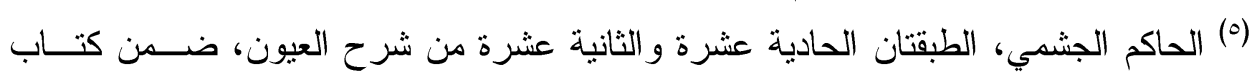

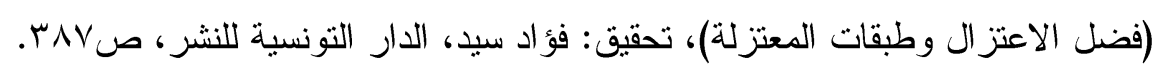

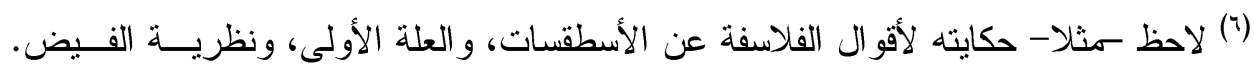

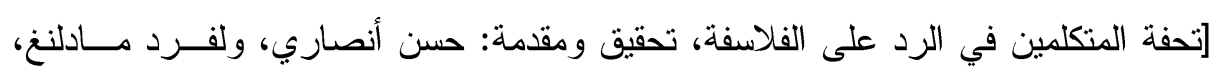

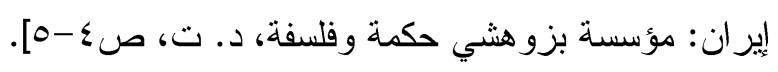


و إنما تجاوزوا ذلك إلى الخوض في مباحث كلامية دقيقة، هي أقرب روحًا إلـى

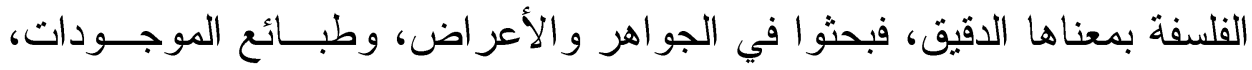
و الجزء الذي لا يتجزأ(')، ونحو ذلك من دقيق الكلام وجليله.

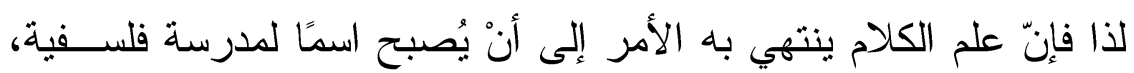

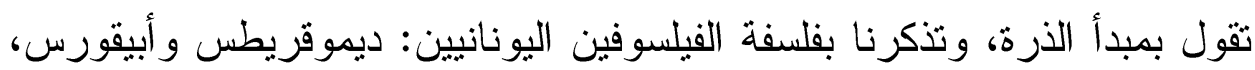

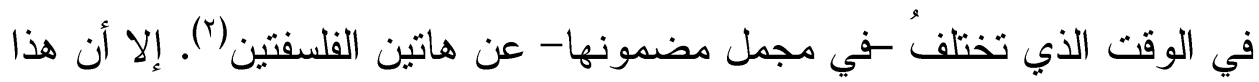
هذا الأخذ أو التأثر لا بعني أبدا مجرد استعارة النظريات على علاتها بقدر مـــا هو صياغة النظريات القديمة في قالب مختلف وتكييفها بحيث تكون عنصر ا من

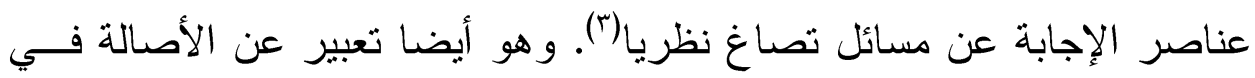
التفكير الكلامي الإسلامي.

(') التفتاز اني، أبو الوفا. علم الكلام وبعض مشكلاته، القاهرة: دار النقافة، د. ت، المقدمة، ص 


\section{المبحث الثاني}

\section{الإلهيات لدى الجويني وصلتها بالمصادر الاعتزالية}

تعد قضية الألوهية أبرز معضلات البحوث الفلسفية، ومن أعقد القضايا في التاريخ؛ لأنها أهم مشكلة واجهت العقل البشري في مراحل تطوره، كما أنها

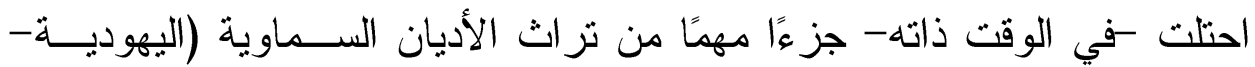
المسيحية-الإسلام) و النحل و التيار ات المتتوعة، ومن ثم اختلفت الحلول، وتباينت التصور ات العقلية لهذه القضية من فلسفة إلى أخرى('). وفي هذا المبحث أتتاول ثلاثة موضوعات من قضايا الإلهيات ومباحثها كما تصور ها إمام الحرمين الجويني، وذللك على النحو التالي: ثانيا: التززيه عند الجويني أولا: الاستدلال على وجود الله

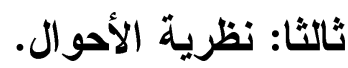

\section{أولا: الاستدلال على وجود اللّه:}

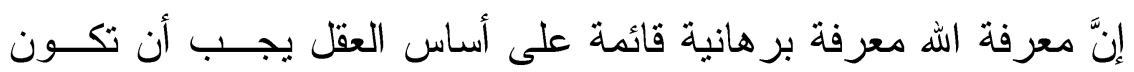

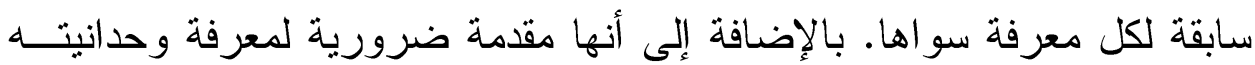

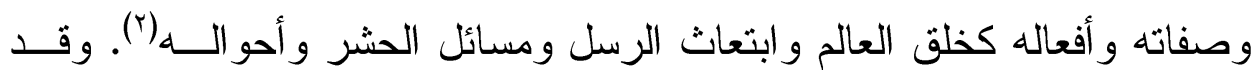
عرض الجويني لدليلين، هما: دليل الحدوث، ودليل الممكن و الو اجب. آدليل الحدوث:

يُعدّ الاستـدلال بحدوث الأجسام على وجــود الله طريقـــــــن طر ائــق المتكلمين العقلية في إثبات الصانع، و المحدث للعالم.

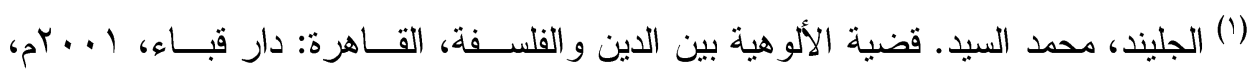

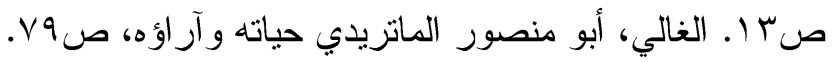

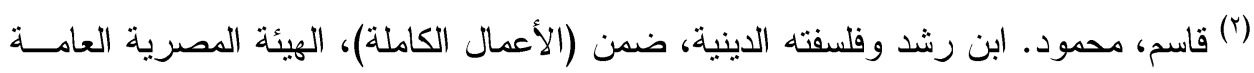

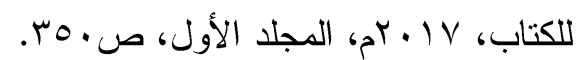


وكان أبو الهذيل العلاف أول من قال بهذا الدليل(')، ثــم تابعـهـه بعـض

المعتزلة كالقاضي عبد الجبار وأبو رشيد النيسابوري(r)، وعن المعتزلـــة تلقـــاه

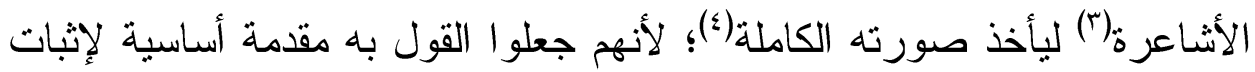

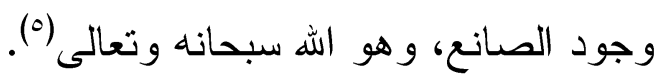
و هذه الطريق في العلم بحدوث العالم، و إثبات الصانع، اختارها متأخرو

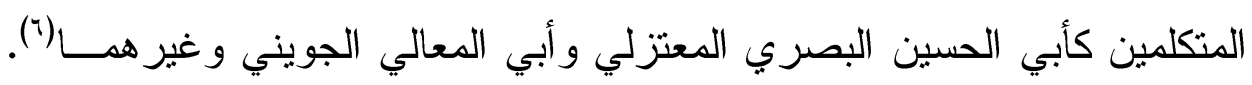
وكان المتكلمون يشرعون في إثبات حدوث العالم عن طريق تقديم مقدمات تختلط فيها الأبحاث العقلية بالأبحاث الطبيعية الفيزيقية (V).

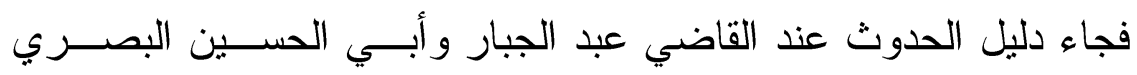
و الجويني وغيرهم مبنيا على أربع مقدمات، هي:(^) إثبات الأعر اض، و إثبــات

$$
\text { (1) شرح الأصول الخمسة، صوبه }
$$

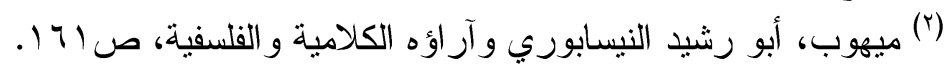

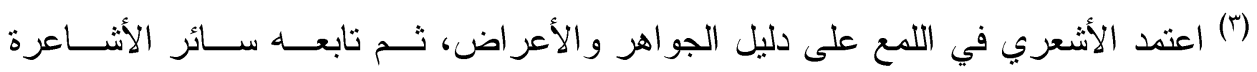

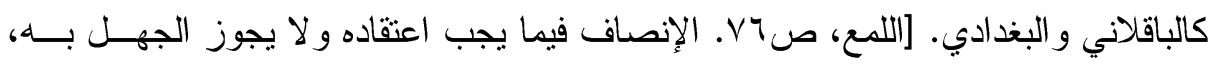

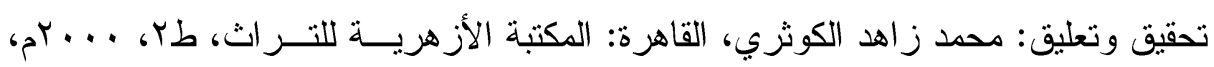

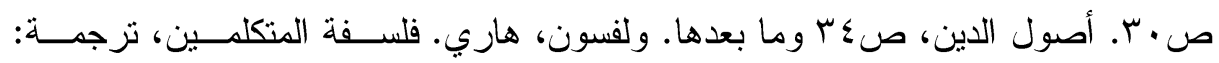

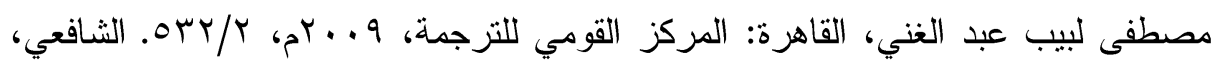

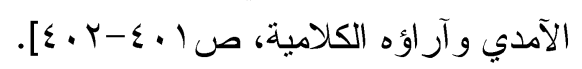

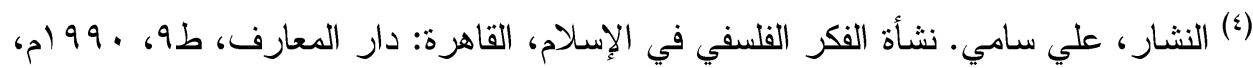
. $\leqslant \vee 0 / 1$

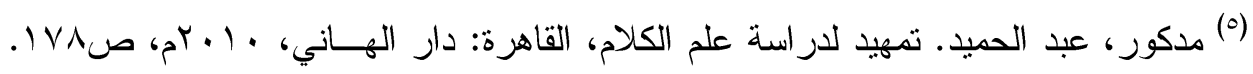

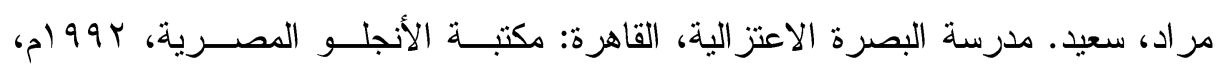
ص صنس. (7) (ج) درء تعارض العقل و النقل، 09/1. (Y) القوصي، محمد عبد الفضيل، هو امش على العقيدة النظامية للجويني، القاهرة: دار الطباعة

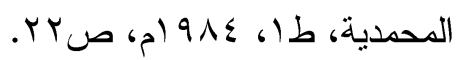

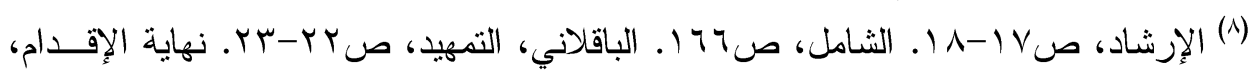

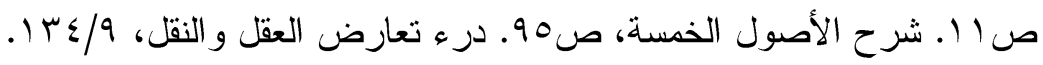


حدوثها، وإثبات استحالة تعري الجواهر عن الأعر اض، وإثبات استحالة حوادث

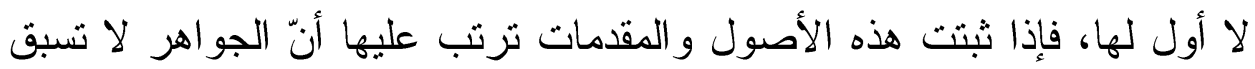
الحو ادث، وما لا يسبق الحو ادث حادث.

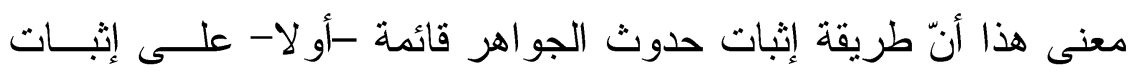

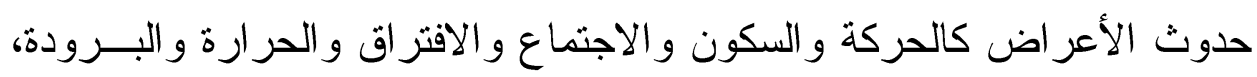

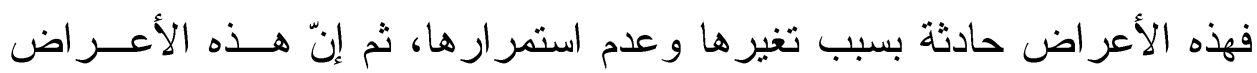
الحادثة ملازمة للجواهر التي لا يمكن تجردها عنها، فلابد أن تكون موصـــوفة فئة

ببعضها.

ويتبين من هذا التلازم أنّ الجواهر حادثة؛ لأن ما لا يخلو عن الحوادث

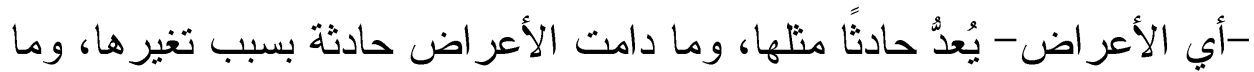

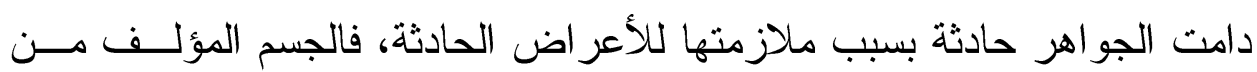
الجو اهر -التي لا يمكن تجريدها من الأعر اض- حادث، وكل حادث يحتاج إلى

من يحدثه ويخلقه، و هذا المحدث الخالق، هو اله تعالى ('). و هذا ما بينه أبو الحسين البصري في كتابه (غرر الأدلة)؛ إذ عقد بابــا

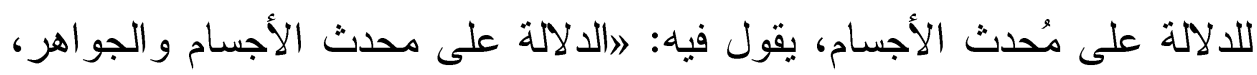

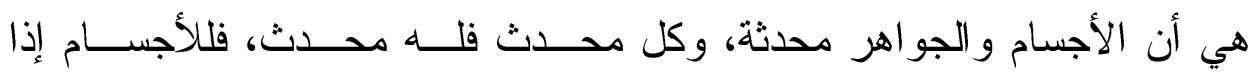

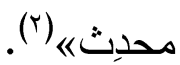

وقد استدل الأشعري على وجود الله تعالى من خلال الاستتاد إلى آيــات

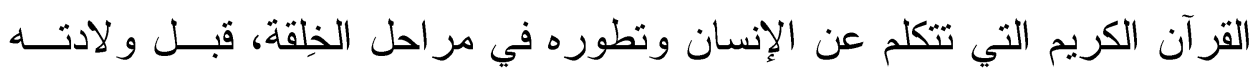
وبعدها، و هو دليل يقوم على فكرة السببية.

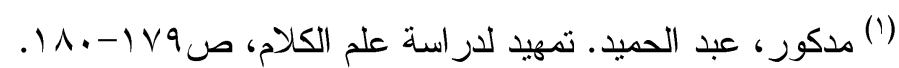

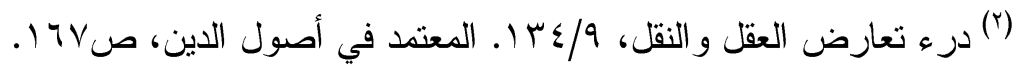


وقد لوحظ أنّ الأشعري اقتصر في كتابه (اللمع)(') على هذا الــدليل (أي

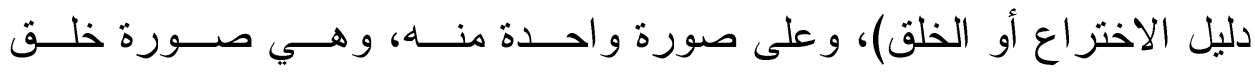
الإنسان (r) (1) (1) وفيما يخص دليل الحدوث، فقد كان هدف القائلين به أن يبينو أنّ الكون في بدايته وفي استمر ار وجوده مفتقر إلى الله، وأن قدرة الله تعالى هي التي تخلق به أن

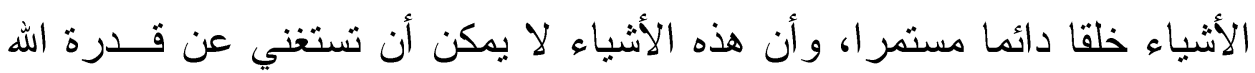
وحفظه لحظة و احدة(").

وتظهر أهميته، كذلك، في إبراز دور المتكلمين في التصــدي للتيــار ات المادية و اللأخلاقية؛ لأنه مبني على حدوث الجو اهر، التي هي قائمة على أصــل إنل

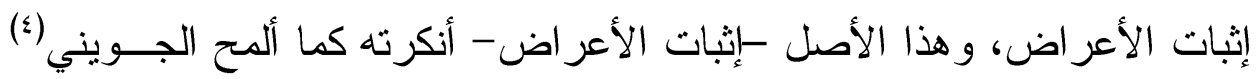

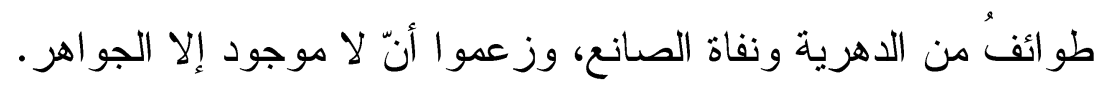

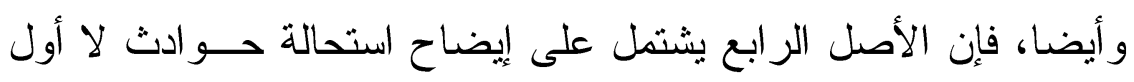
لها. لاو الاعتتاء بهذا الركن حتم، فإن إثبات الغرض منه يزعزع جملة مــذاهب لهب

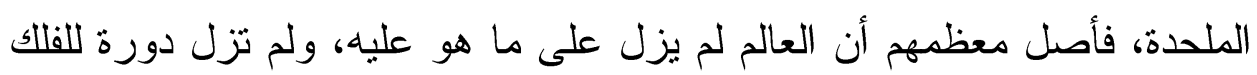
قبل دورة إلى غير أول، ثم لم تزل الحوادث في عالم الكون و الفساد تتعاقب كذلك دئل إلى غير مفتتح، فكل ذلك مسبوق بمثله، وكل ولد مسبوق بو الدها(ْ). يدل هذا على أن صياغة هذا الأصل مسوقة لإبطال لرأي أرسطو فـي ولي القدم، بإبطال إمكانية التعاقب بلا نهاية(؟).

$$
\text { (') (اللمع، ص/19-19) }
$$

(r) الزركان، محمد صالح، فخر الدين الرازي وآراؤه الكلامية والفلسفية، بيروت: دار الفكر،

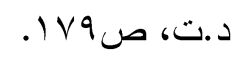

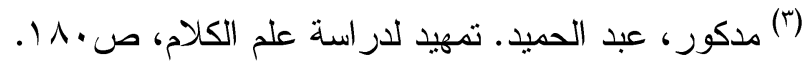

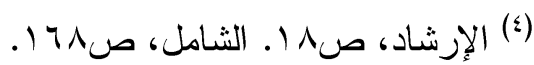

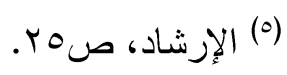

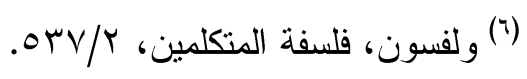


بيد أنّ هذه الأهمية، وذالك الهدف، لم يمنع أبي منهما بعـض المتكلمـين

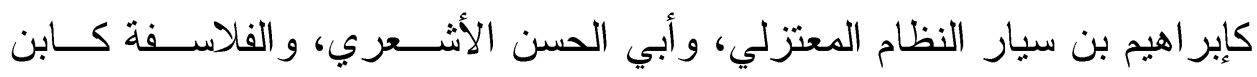
رشد(ت 090هـ) من نقد هذه الطريقة في الاستدلال.

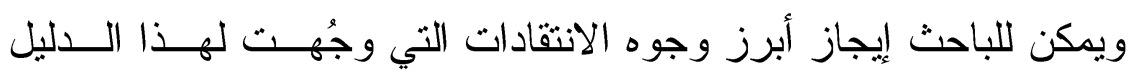

فيما يلي: (') أ- الاعتماد على مقدمات غير و اضحة و لا يقينية، و هذا جلي فيما بذله المتكلمون لإثبات صحة المقدمات التي اعتمد عليها هذا الدليل، فقد اضطروا إلى البرهنة

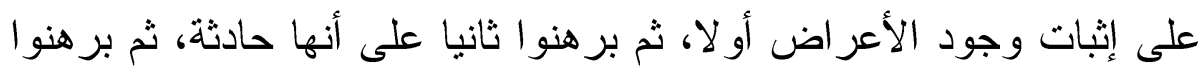

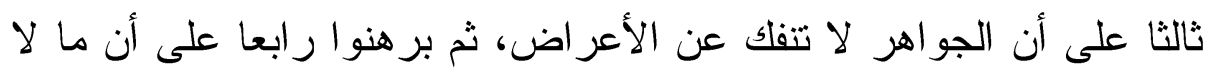
ينفلك عن الحو ادث حادث.

ب- قولهم بأن الأعر اض كلها حادثة لا يصدق على جميع الأعر اض، بل ينطبق

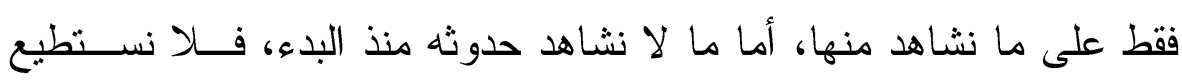

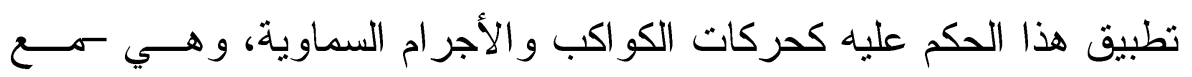
ذلك - غير متغيرة؛ لأنها تسير على نمط ثابت وقانون مطرد لا يتغير.

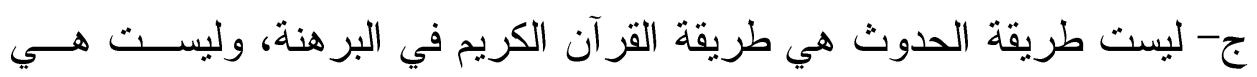
التي دعانا الله عز وجل ورسوله -صلى الله عليه وسلم- إلى الإيمان به عن طريقها.

د- هذه الطريقة تؤدي إلى ما أسماه الفلاسفة بالاســنغناء، وملخصـــه أنّ الله إذا

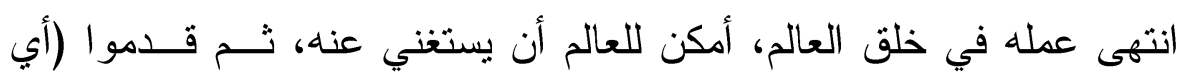

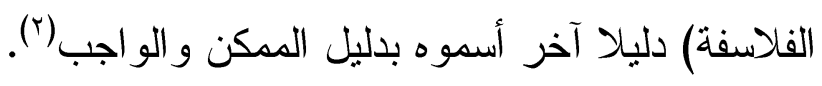

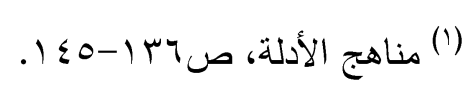

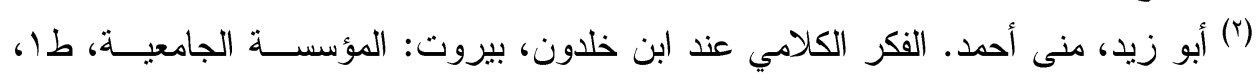

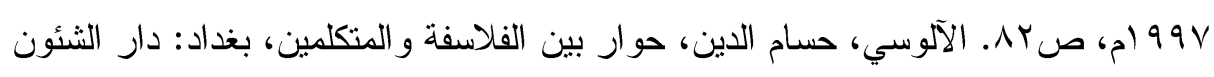

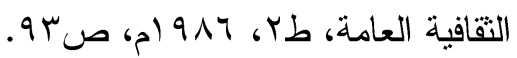


هـ- يترتب على ما سبق، أنّ هذه الطريقة في الاستدلال ليســت هـي أمثنـل

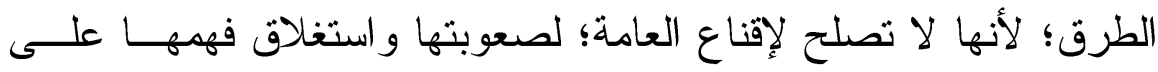
أذهانهم، بسبب ما فيها من مصطلحات غامضة ومقدمات معقدة، كــذلك لا لا لهات

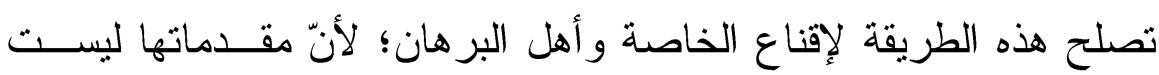

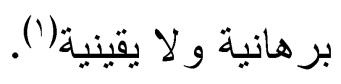

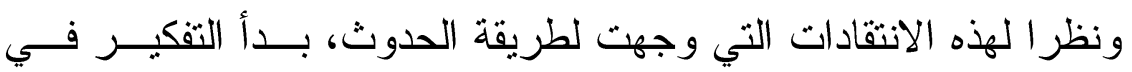
طريقة أخرى جديدة؛ لإثبات وجود الصانع، وهي طريقة الإمكان أو الترجيح أو وجي

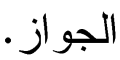

فقد تحول الجويني عن طريقة الجواهر والأعر اض إلى طريقة الإمكــان

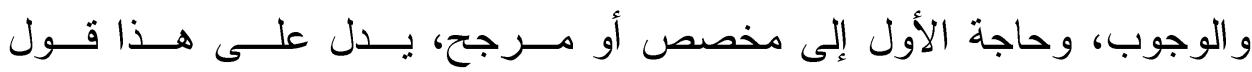
الشهرستاني بعد تتاوله طريقة الحدوث عن طريق الجواهر و الأعر اض:او اعتمد إمام الحرمين كرضي الله عنه- طريقة أخرىه(؟).

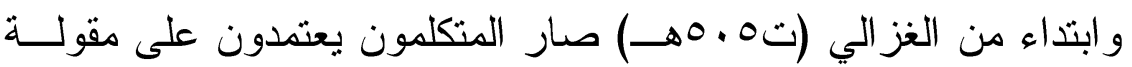

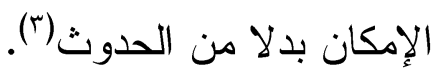

r - دليل الإمكان أو التخصيص (دليل الممكن والواجب): يعزو بعض الباحثين (£) أصول هذا الـــليل إلــى القاضـــي أبــي بكـر

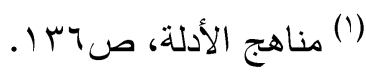

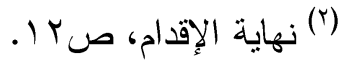

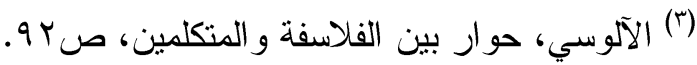

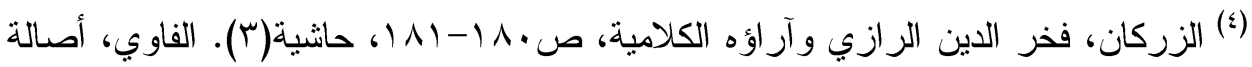

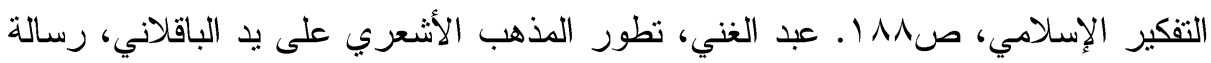

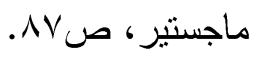

- See: Fakhry, Majid. The Classical Islamic Argument for the Existence of God, The Muslim World, april 1957, page 139. 


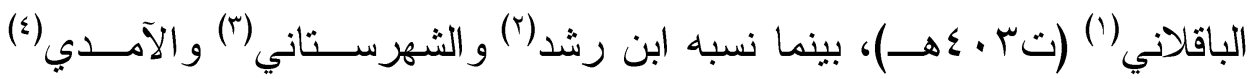

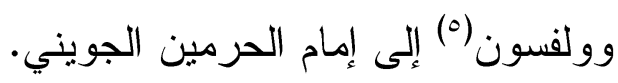

لكن المؤكد لديّ أن جذور فكرة التخصيص و الجواز أقدم من البــاقلاني

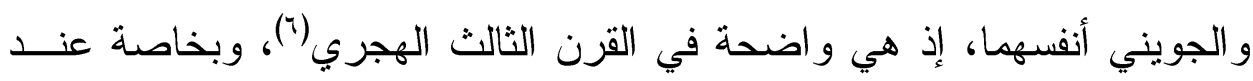

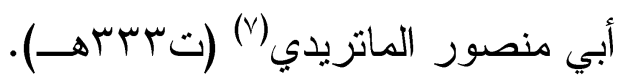

وهذا يقتضي أن نتساءل: من أيّ المصادر استفاد الجويني هذا الدليل؟

أ- هناك من يرى أنّ الجويني استفاد فكرة هذا الدليل من الفلاسفة القائلين بدليل

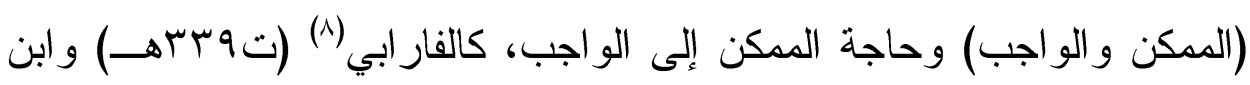

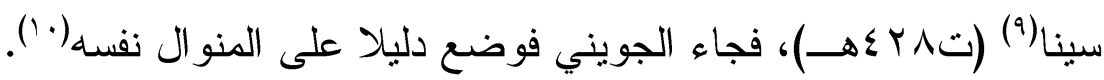

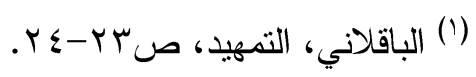

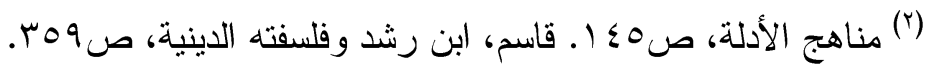

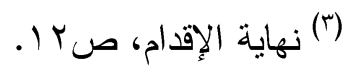

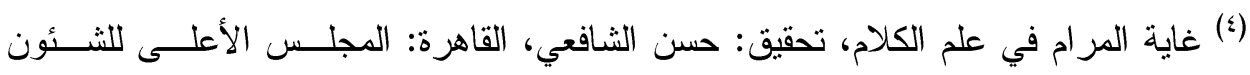

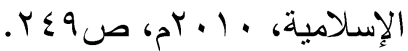

$$
\begin{aligned}
& \text { (0) ولفسون، فلسفة المتكلمين، }
\end{aligned}
$$

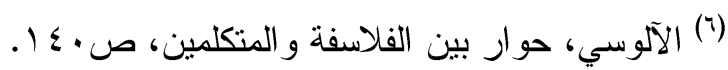

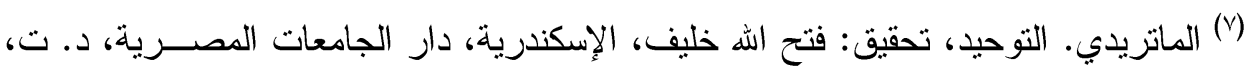

$$
\text { صن IV }
$$

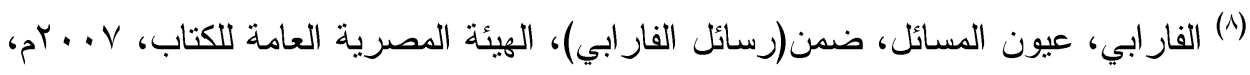

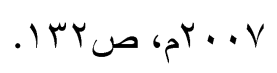

(9) Herbert Davidson says: ameasure of the influence of Avicenna's proof is the fact that Necessarily Existent became an accepted synonym for God in Islamic and Jewish theology.

See: Proofs for Eternity, Creation and the Existence of God in Medieval Islamic and Jewish Philosophy ,(Oxford University Press 1987), page 387.

(·) أبو زيد، منى. الفكر الكلامي عند ابن خلدون، صبر-بر. المغربي، الفرق الكلاميـة،

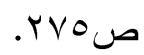


لكن الأقرب للموضوعية أن نغاير بين فكرة الإمكان عنــد ابــن ســينا و الجويني، فإن كان الغرض عند الأول هو تشييد مذهب، فإن غرض الثاني هو تأسيس معتقد (')

أضف إلى ذلك، فإن الجويني انتهى إلى أن مخصص الحوادث فاعل لها على الاختيار، فهو يفعل بمشيئة حرة، وهذا على خلاف ابن سينا الذي انتهى إلى إلى

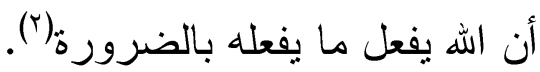
ب- وثمة من يرى أنّ فكرة الإمكان قد بدأت في الوسط الكلامــي، واســتعار ها

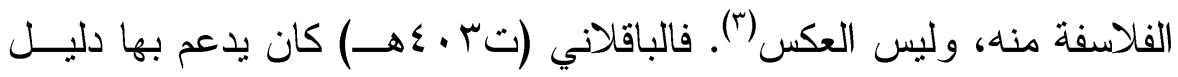

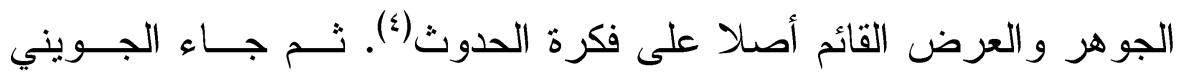
فأفردها دليلا مستقلا.

وربما يكون منشأ هذه الفكرة بتأثير من (دليل التخصيص) الذي اســتل

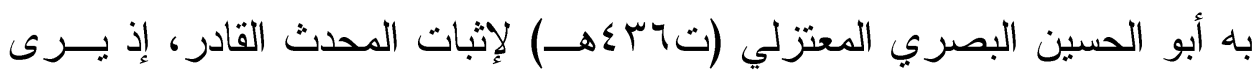
أنّ أجزاء العالم مشتركة في الجسمية، ومفترقة في الصور، فنجد بعضها مــاء،

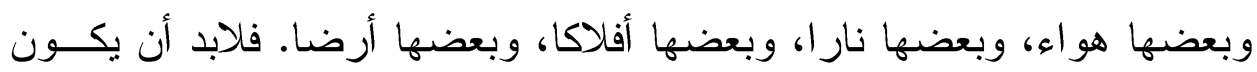

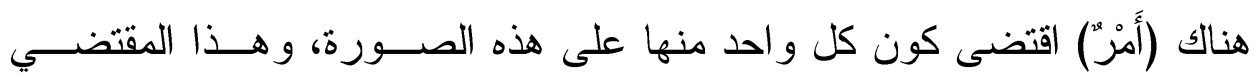

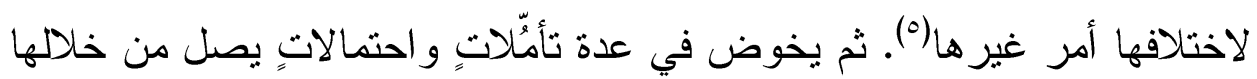
خلالها إلى أنّ ذلك لابد أن يكون من فعل قادرٍ مختار، و إذا ثبت القادر الجاعـلـل

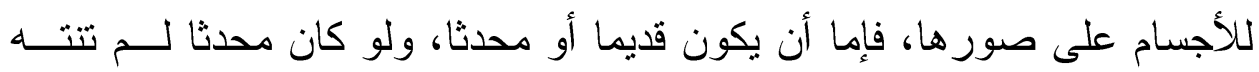

(1) القوصي، هو امش على العقيدة النظامبة، صلV. (1).

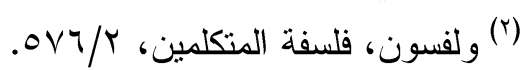

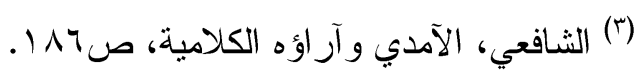

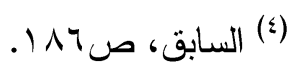

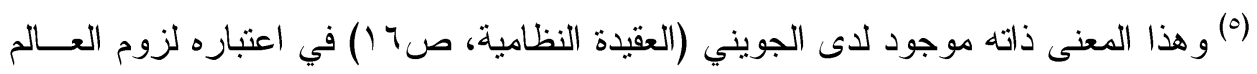

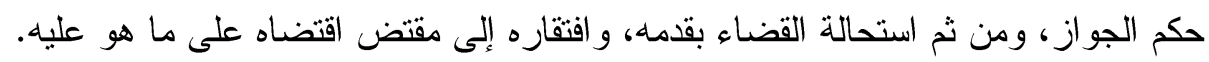


الحوادث، فلزم أن يكون قديما، كما يستحيل أن يكونَ جسما أو عرضـا('). وقــد

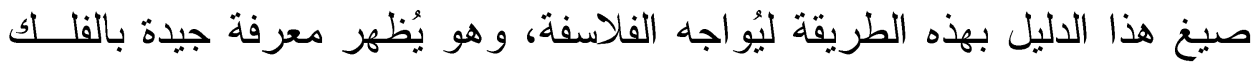
و الطبيعة لاى أرسطو (r). يتبين من هذا أن الباقلاني و أبا الحسين البصري كانا أسبق زمنــا مــن الجويني في استخدام هذا الدليل والاحتجاج به، وأنه من العسير أن نرتضي قول بعض الباحثين(ّ) في اعتبار الجويني مستتبطا هذه الطريقة ور ائدا لها بعد عرضه ونه عرضه لطريقة الحدوث. أما صورة هذا الدليل فبعبارة الجويني، أنه إذا ثبت حدث العالم، فالحادث جائز الوجود، فقد يجوز تقدير وجوده بدلا عن عدمه، وقد يجوز تقدير عدمه بدلا

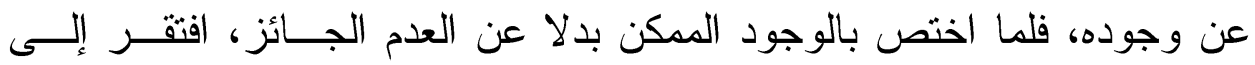

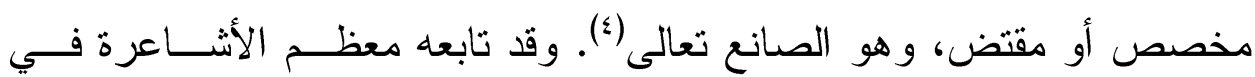
ذلك (0).

ومعنى هذا، أن هذا الدليل يقوم عند القائلين به على مقدمتين:

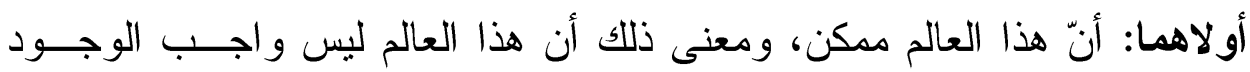
لذاته، بل هو ممكن الوجود و العدم بالنظر إلى ذاته. فالعالم -بجميع ما

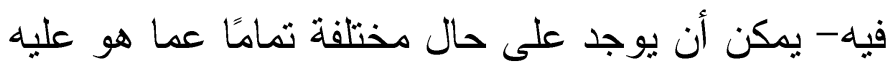
وثانيهما: كل ممكن يحتاج إلى مخصص ومرجح. إذن، العالم يحتاج إلى مُخصص، وهو الله تعالى.

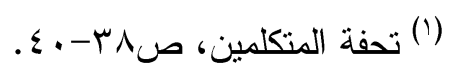

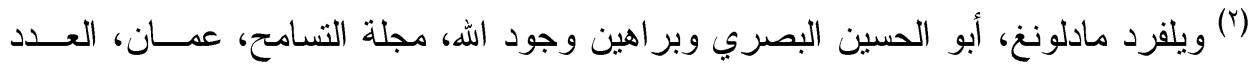

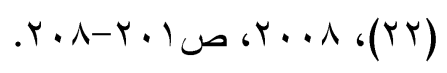

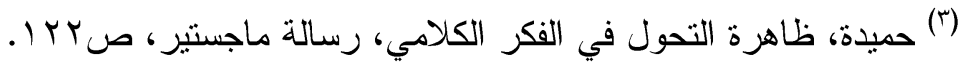

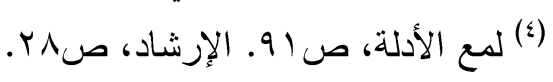

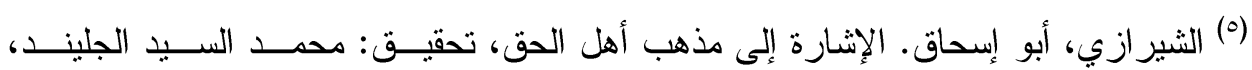

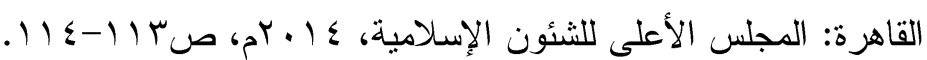


و على الرغم من نقد الشهرستاني(')، وابن رشد، والآمدي(r) لهذا الدليل،

فإن توماس الأكويني (ت ع Y (م) استخدمه في عرض مذهبه، في البرهنة على خلق العالم وحرية الإز ادة الإلهية(؟).

\section{ثانيا: التنزيه عند الجويني:}

ذهب الجويني إلى تنزيه اله عن النقص، فلا يتصف بالصفات الدالة على

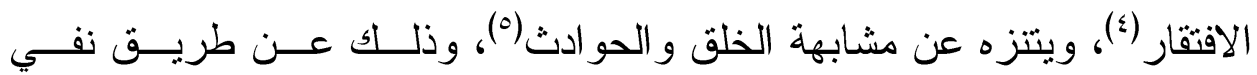

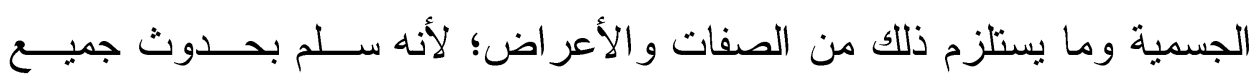
الأجسام لملازمتها للأعر اض التي هي الصفات، فيجب أن يكون الرب منزهــــا عن كل صفة تستلزم التركيب أو الجسمية أو الحلول و الاتحاد. 1-نفي الجسمية عن الله تعالى:

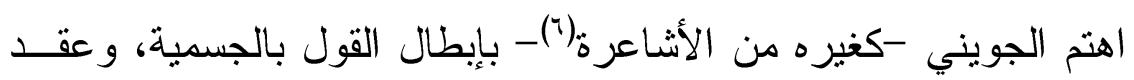

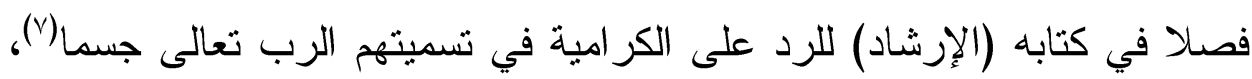

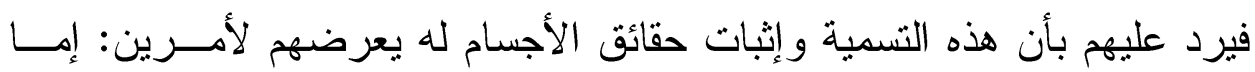

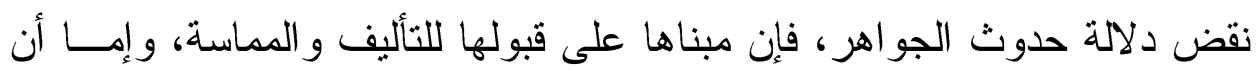
تطردوها وتقضوا بقيام دلالة الحدوث في وجود الصانع، وكلاهما خروج عـنـ

$$
\begin{aligned}
& \text { (') نهاية الإقدام، صـ (. (1) }
\end{aligned}
$$

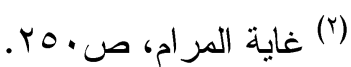

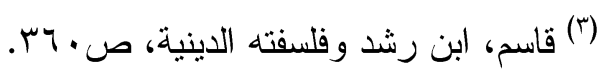

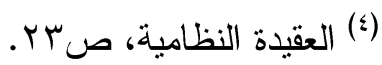

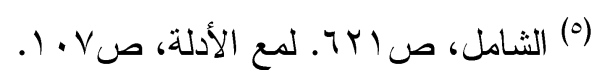

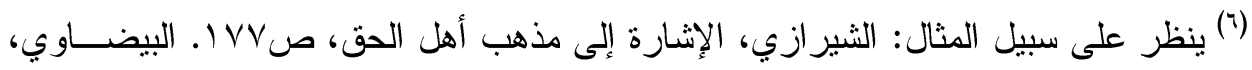

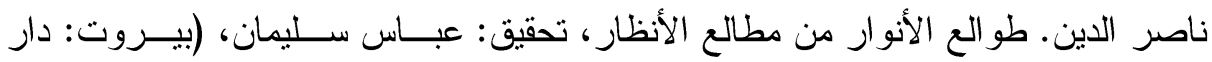

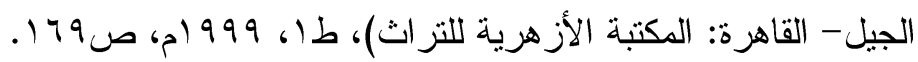

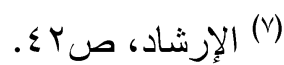


الدين ('. ثم تجاوز ذلك إلى إبطال كل لوازم الجسمية من المماســة و المحــاذاة، و استتكر كل ما يؤدي إلى تقدير الإله وتبعيضد. r- إبطال الاختصاص بالجهات والاتصاف بالمحاذاة: يدل على ذلك أنّ كل مختص بجهة سثاغل لها- متحيز، وكل متحيـز قابل لملاقاة الجواهر ومفارقتها، وكل ما يقبل الاجتماع و الافتراق لا يخلو عنها، وما لا يخلو عن الاجتماع والافتزاق حادث. و إذا ثبت ثقد الباري عن التحيز، و الاختصاص بالجهات، فيترتب على ذلك تعاليه عن الاختصاص بمكان، وملاقاة

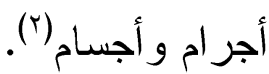
كما يقرر الجويني -في رده على الكر امية وبعض الحشوية- بأنّ مذهب الأشاعرة هو أنّ الله يتعالى عن التحيز و التخصص بالجهات(؟). r-نفي حلول الحوادث بذاته تعالم: لما ذهبت الكر امية إلى أنّ الحوادث تطر أ على ذات الرب تعالى (؛)، فإن الجويني يدلل على بطلان قولهم بأنه لو قبل الحوادث لم يخل منها، بناء على ما سبق تقريره في الجواهر، إذ إنها لا تتفك عن الأعر اض، وما لـــ يخـلـ مــن الحو ادث لم يسبقها، وينساق ذلك إلى الحكم بحدوث الصانع(ْ). و هذا التنزيه الذي أبانه الجويني آنفا لم يختلف عما ذهب إلبه متــأخرو المعتزلة، لاعتقادهم وجوب نفي كونه تعالى جسما، وما يتبع الجســية ككونـــه جرمًا وحجما، وينفون عنه حقائق الأعر اض وما يتبع ذلك(؟).

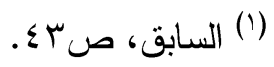

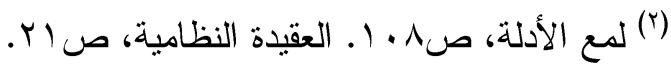

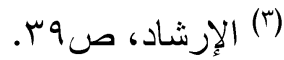

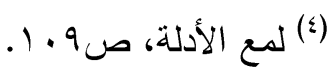

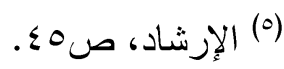

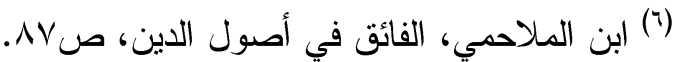




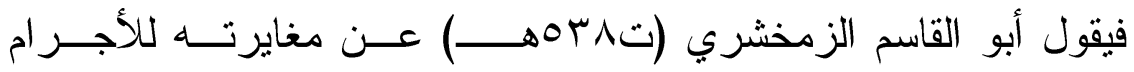
و الأعر اض:»اعلم أن محدث العالم شيء مخالف لسائر الأشياء، ليس بجســم ولا عرض، ولا مشبه لهما بوجه من الوجوه، ولا يشغل جهة، ولا يحل في جـرم، ولا يكون في مكان، و لا يدرك بحاسة من الحواسها" ('). كذلك، اجتهدوا في إسقاط التفسيرات الحسية المادية للفرق و التيار ات التي أضفت على اله تعالى أوصافا تحاكي الصفات الإنســانية وتماتلهـــا؛ لــذا فــانْ متأخري المعتزلة يجتهدون في التأويل الآيات التي يتعلقــون -أي المجسـمة-

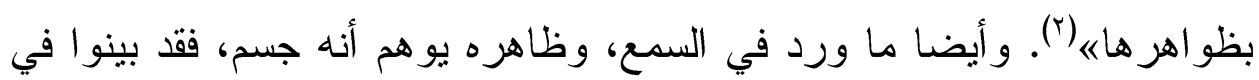

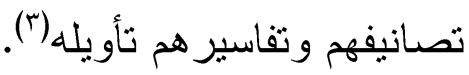
و على الرغم من تمسك الأشاعرة بنفي الجسمية، وتأويل ما يو همها مــن

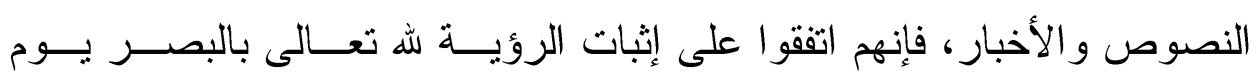

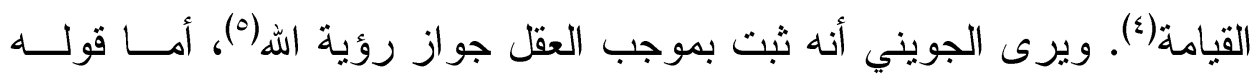

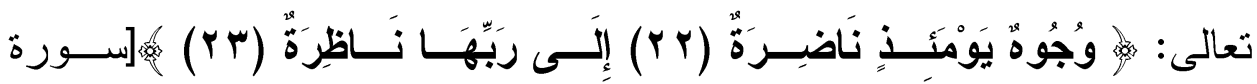

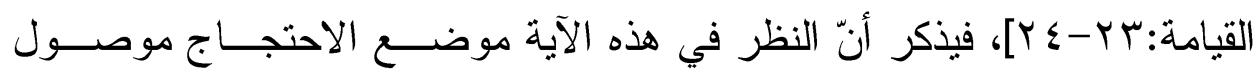
بحرف الجر إلى، وهذا اخبر عن الوجوه الناظرة المستبشرة، فاقتضـاء النظـــر

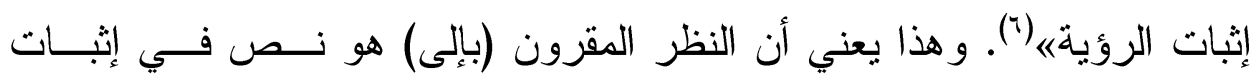

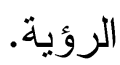

(1) الزمخشري، المنهاج في أصول الدين، تحرير وتقديم: سابينا شـــيدكه، بيـروت: الــــار

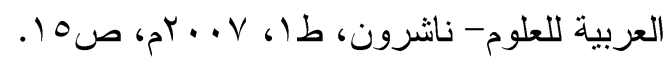

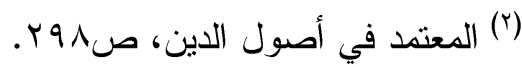

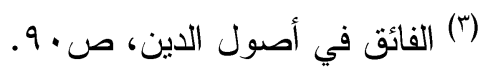

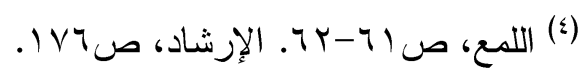

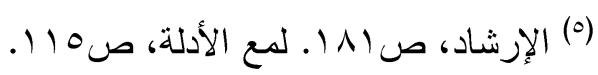

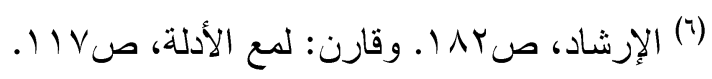




\section{ثالثا_ نظرية الأحوال:}

حاول أبو هاشم الجبائي(ت ابrهـــ الوصول إلى حل لمشكلة العلاقــة بين الذات الإلهية وصفاتها، وذلك عن طريق "الأحو ال" كمحاولة للتوفيـق بــين التنزيه المطلق، وبين جواز اتصاف اله تعالى ببعض الصفات(1). وقد اختلف الجبائيان في كيفية استحقاق الله تعالى لصفاته، فــذهب أبــو علي إلى أنه يستحق هذه الصفات الأربع، الني هي كونه قادرا عالما حيا موجودا لذاته، في حين ذهب أبو هاشم إلى أنه يستحقها لما هو عليه في ذاته(ب). ويلــوح من هذا التعبير لأبي هاشم بذور نظرية الأحوال(")، فهو أول من أحدث القــول فيها (घ)

فو احدنية الله لا تقتضي تعطيل معاني الصفات، لقد ميز أبو هاشم بـين مجالين: مجال الذات و انتمائها إلى عالم الأعيان، ومجال الصفات و انتسابها إلى الأذهان، ثم حدد العلاقة بينهمان). فالأحو ال ليست صفات بالمعنى المتبادر إلىى الذهن، و إنما هي أحوال لا معلومة و لا مجهولة، و لا موجودة ولا معدومة، و لا قديمة و لا محدثة، أي هـي إي على حبالها لا تعرف كذلك، بل مع الذات(؟).

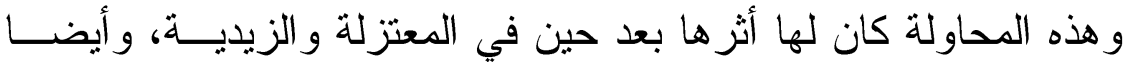
الأشاعرة، فظهرت عند بعض شيوخ المذهب الأشعري، كالباقلاني و الجويني.

$$
\begin{aligned}
& \text { الر اوي، العقل و الحرية، ص^^ץ. }
\end{aligned}
$$

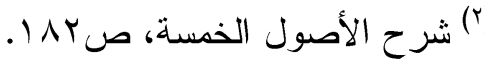

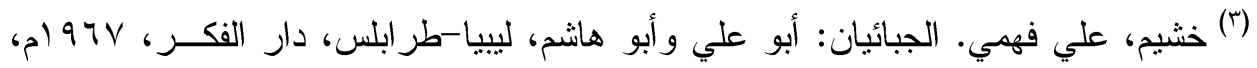

$$
\text { صو }
$$

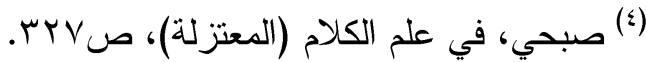

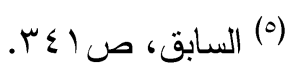

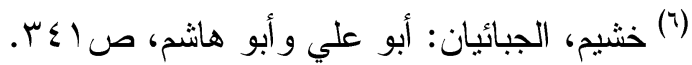




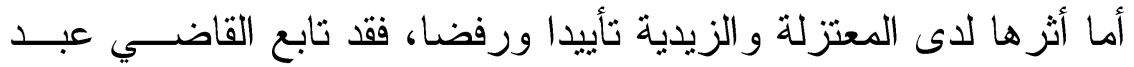

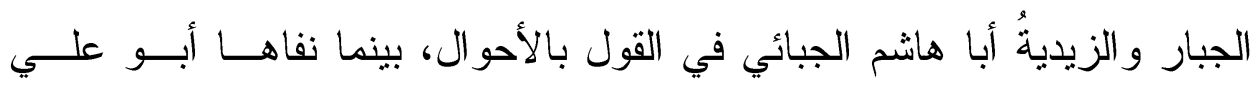
الجبائي (')، وأبو الحسين البصري(بارئ)، وركن الدين الملاحمي.

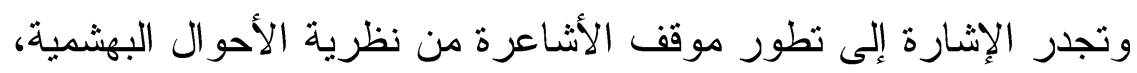

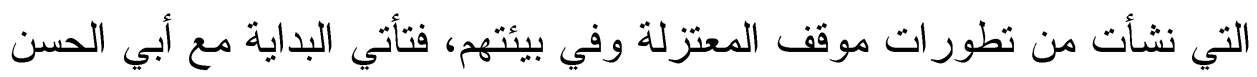
الأشعري الذي رفضها بموجب تصوره الميتافيزيقي، فيحكي عنه الجويني قائلا:

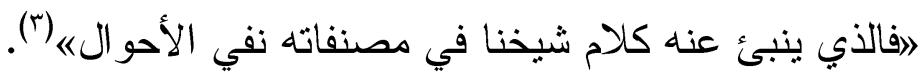

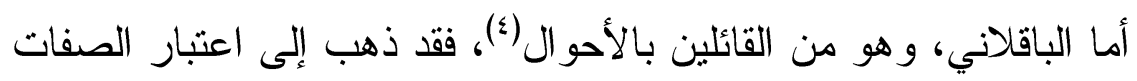
الصفات أحوالا (أو وجوها) للذات الإلهية، وعن طريق هذه الصفات (الأحوال) تدرك الذات(0). - (ن)

ثم تبناها إمام الحرمين الجويني-الذي كان متأثرا ببعض آراء أبي هاشم

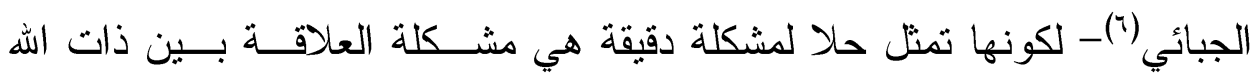

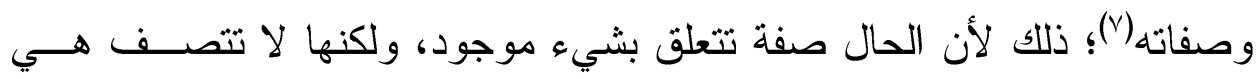

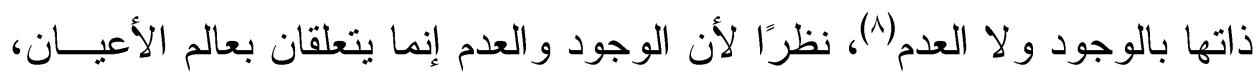

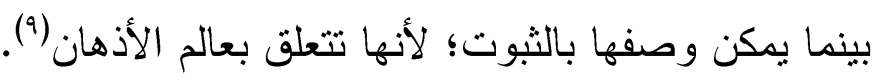

$$
\begin{aligned}
& \text { (1) صبحي، في علم الكلام (المعتزلة)، صوسب. }
\end{aligned}
$$

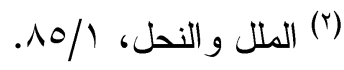

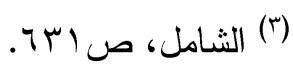

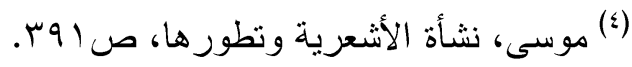

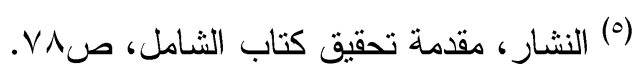

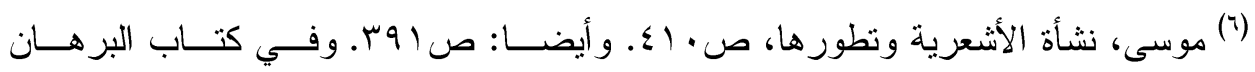

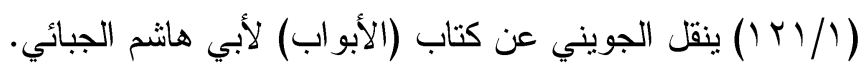

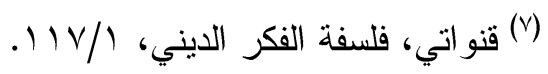

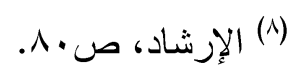

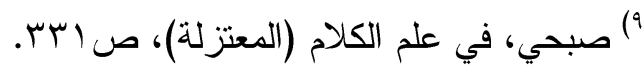


فيقول الجويني: 》الذي يقوي عندنا إثبات الأحو ال، وهذه مسألة عظيمــة

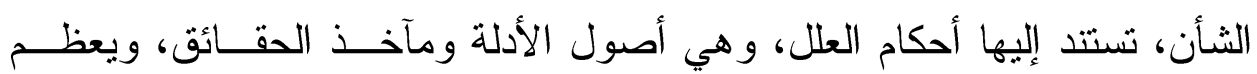
خطر ها من حيث تتطوي على مخالفة معظم الأصحابه ('). يشير هذا النص إلى عدد من الدلائل، يمكن استنباطها على النحو التالي: 1- عِظم شأن هذه المسألة في الفكر الكلامي؛ إذ تستند إليها أحكام العلل. r-يقول الجويني بإثبات فكرة الأحوال، ويظهر للباحث أنه لم يكن بدعا في ثلك المخالفة للتقليد الأشعري؛ لأن هناك من الأصحاب من يؤيده في إثباتها. r- معظم أصحابه يستتكرون القول بالأحو ال. 


\section{المبتشث الثالث}

\section{التأويل الكامي عند الجوبني \\ (قنية الصفات الخبرية أنموذجيات}

كان المذهب الأشعري في عهوده الأولى، وبخاصة على يد مؤسسه أبي

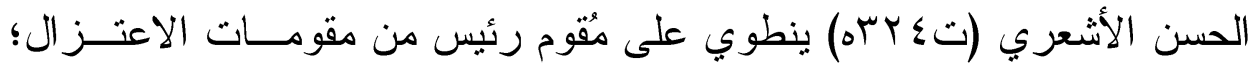

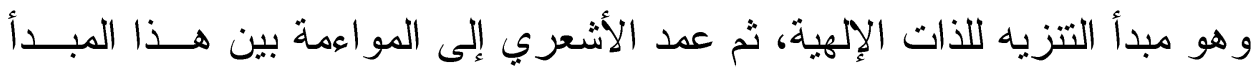
وبين نزعة الإثبات(')، ثم بدأ التطور تدريجيا بالتخلي عـن طريقــة الأشــعري المتوسطة بين الإثبات و التتزيه، و التحول نحو التنزيه الاعتز الي عند البـاقلاني (ت • عـه) الذي أوّّل ما يُوهم التغير في ذات الله تعالى من الصــفات الخبريـــة كالرضا و الغضب و السخط(؟)، و أبي بكر بن فُورك (ت ج + عه) الذي أثبت ما جاء في القرآن الكريم من اليد و الوجه و العين صفات قديمة ليست كصــفات البشــر ، و أوّل ما في الأحاديث و الأخبار كالقدم و الساق وما يفبد التغير النفسي كالغضـــب

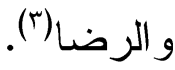
ثم تز ايد التحول و النزوع نحو التنزيه الاعتز الي على يد عبــــ القــاهر

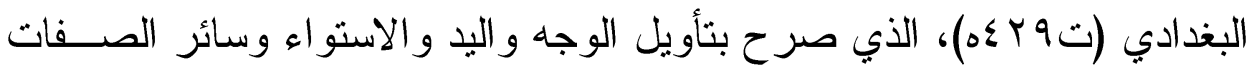

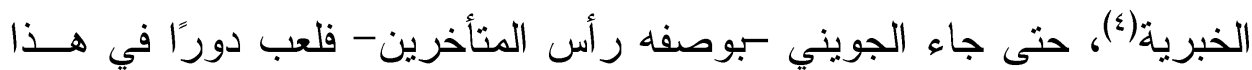
المسار وتحو لاته، وتابعه متأخرو الأشاعرة كالر ازي (ت7 + جه) وسيف الـدين الآمدي (0) - (ت اسبحه).

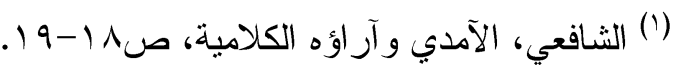

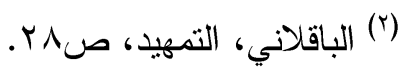
(ץ) ابن فورك، مشكل الحديث أو تأويل الأخبار المنشابهة، تحقيق: دانيال جيماريــه، دمشـق :

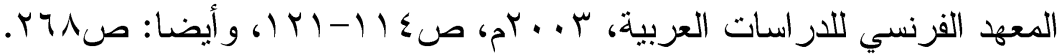

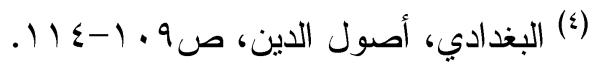

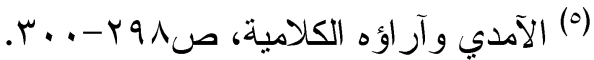


ومن ثَمّ ضاقت هوة الخلاف بين المعتزلة و الأشـاعرة(') في بعض مسائل

الإلهيات.

\section{أولا_ دواعي اختيار قضية الصفات الخبرية:}

تحتل مشكلة الصفات الإلهية عامة مكان الصدارة والأولوية في تـــراث

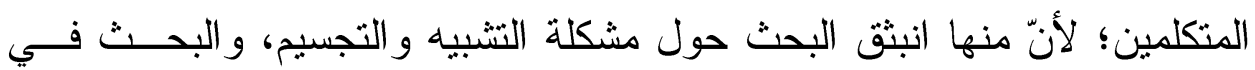
القضاء و القدر، و العدل الإلهي، و علاقة الله تعالى بالإنسان، فهي تمثل روح علم

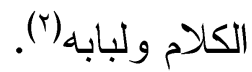

وكان أصحاب المدرسة الجبائية خاصة(؟) يديمون النظر و البحــث فــي

الصفات الإكهية وما يدور حولها، وقد نلحظ أثز ذلك في كتب القاضي عبد الجبار

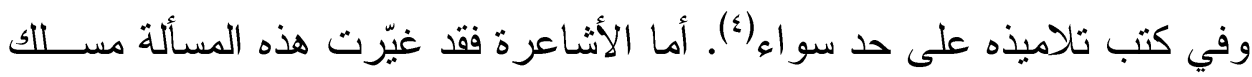

تطور هم (ن).

و على أية حال، فالمعتزلة ومعها الأشاعرة اهتمتا اهتماما رئيسا بمشكلة

الذات الإلهية و علاقتها بالصفات(؟).

ويعود اختيار مسألة الصفات الخبرية خاصة إلى ثلاثة من الأسباب، هي: الإله 1- أنّ أغلب التأويلات الكلامية دارت حولهار.

(') يظهر هذا التقارب المذهبي بصورة واضحة في المنتج الفكـرب لســــ الــدين الآهـدي

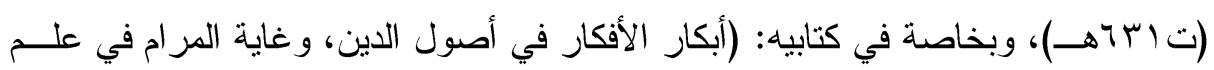

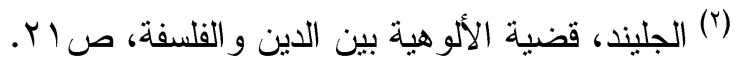

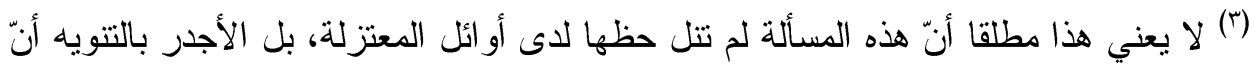

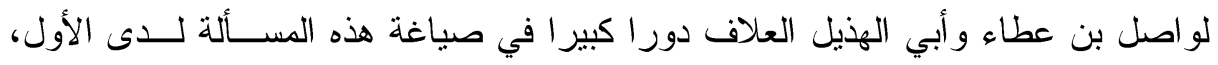

$$
\text { وتعقيدها فلسفيا لدى الثاني منهما. }
$$

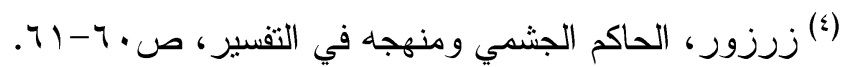

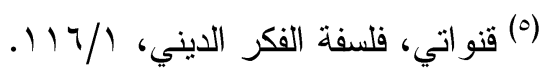

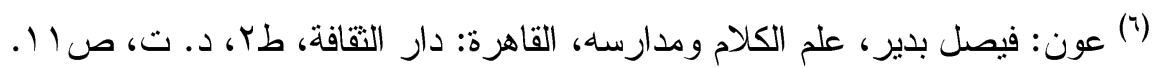


ץ-ارتباطها بمفهوم المحكم و المتشابه(')، إذ إنّ المحكم هو كل ما عُلــم معنــاه،

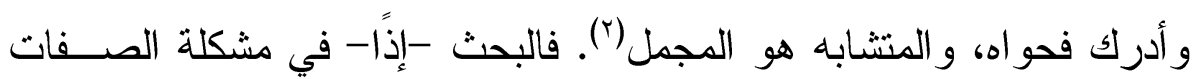

يرجع -في المقام الأول- إلى النص الديني آّاء.).

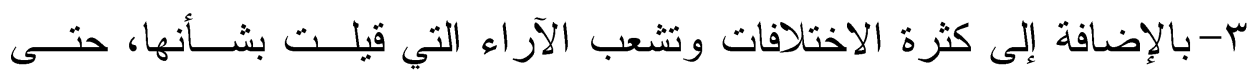

صارت هذه القضية بمثابة أحد الفروق المميزة بين مذهب كلامي و آخر (ء).

\section{ثانيا_الأسباب التي دفت الجويني والمعتزلة إلى التاويل:}

يقصد بالصفات الخبرية هي تلك الصفات التي أخبر الشرع عنها، وليس

عليها دليل عقلي ور اء النص، بل قد يتو هم من إثباتها -حسب ظاهر ها- تشــبيه الله تعالى بالمخلوقات و المحدثات ذوات الجرْم و الأبعاض و الانفعالات و التغيرات، وذلك كالوجه و اليدين و الساق و العينين، و الاستو اء على العرش، ونزوله تعـالى ولى

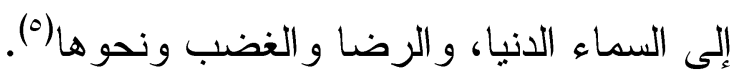

يُستنبط من هذا القول أمر ان مهمان، سببا ضرورة اللجوء إلى التأويل:

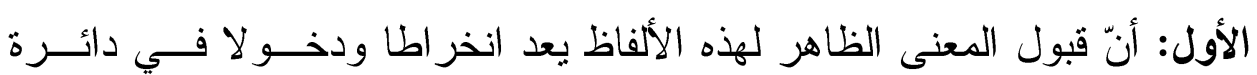

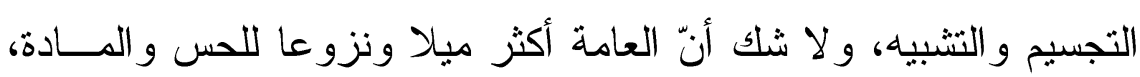

$$
\text { وبعدا و إعر اضا عن مقتضى العقل و التجريد. }
$$

فرجال المعتزلة ومتأخرو الأشاعرة -كالجويني- يشتركون في القول بأنّ

ظاهر بعض النصوص يو هم التشبيه و التجسيم.

(') لا يفتأ المتشابه أن يكون مجالا خصبا لتأويل النصوص وقر اعتها قر اءات متعـددة، وقــــ

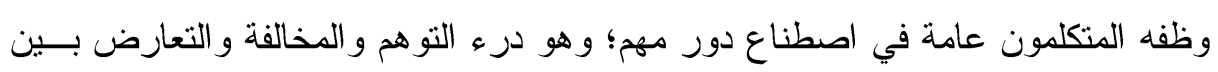
العقل و النقل.

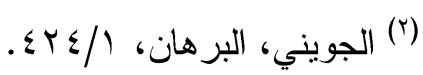

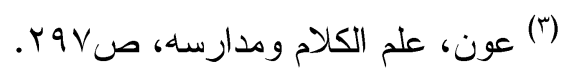

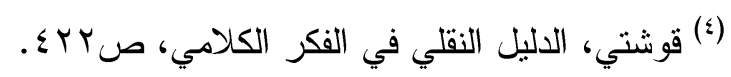

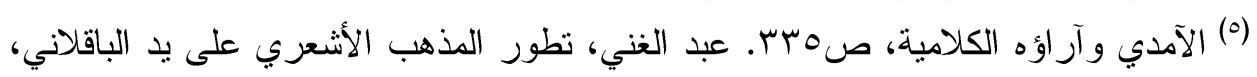

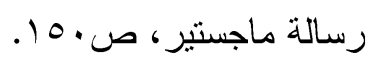


ومثال ذلك، أنّ الجويني يُشير إلى أنّ 》إجر اء الاستواء على ما بنبـى هـ

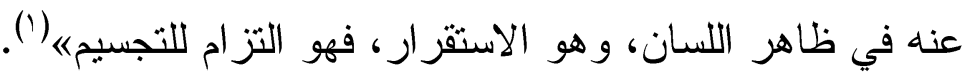

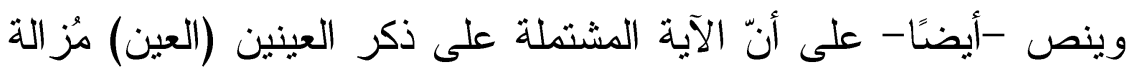

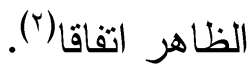

وبناء عليه، فمن الواجب أن تؤول هذه النصوص وأثباهها تحقيقا لمبدأ

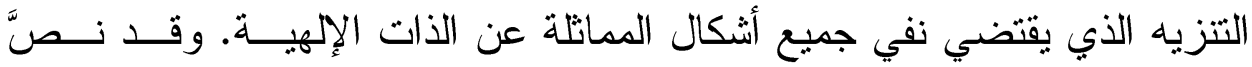

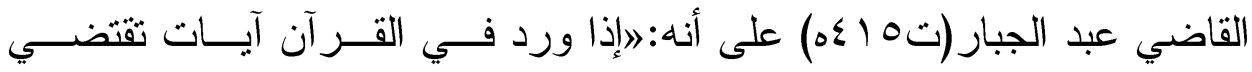
بظاهر ها التشبيه وجب تأويلهاه (r). أما الجويني فذهب إلى أنه إذا كان للتأويل مجال رحب، فلا معنى لحمل الآية على ما يقتضي تثبيت دلالات الحدوث(؛). والثاني: أنها ألفاظ وردت في نصوص نقلية تحتمل التأويل، فدلالتها غير قطعية. لذا أصبح العقل هو الفيصل و المحك في فهم هذه النصوص وتأويلها.

\section{ثالثا_ تأويل الصفات الخبرية بين الجويني والمعتزلة:}

كان موقف الأشـاعرة قبل الجويني من الصفات الخبرية علــى درجــات

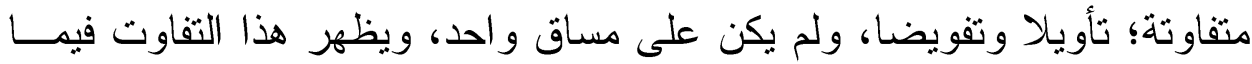
يلي: ا.فيما يخص صفة الوجه والعين واليدين، فجمهور الأشاعرة قبل الجويني على إثباتها بدون تأويل، ويَعدُّ عبد القاهر البغدادي أول مَنْ قام بتأويلها، إذ يصر ح

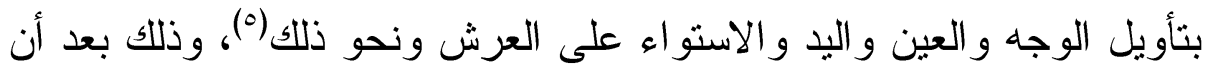

$$
\begin{aligned}
& \text { (1) (الإرشاد، ص اع. }
\end{aligned}
$$

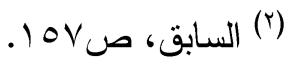

$$
\begin{aligned}
& \text { (") المحيط بالتكليف، ص199 } 199
\end{aligned}
$$

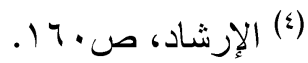

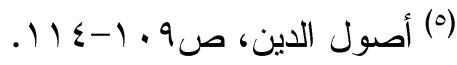


أن يذكر دعوى المشبهة بأنّ لله وجها و عينا كوجه الإنسان وعينــه، فيقـول:

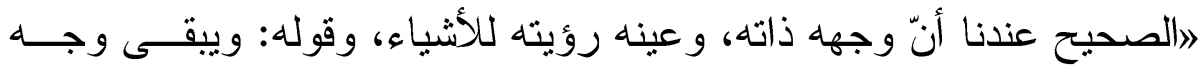
ربك معناه ويبقى ربك ها" (') و إذا كان أبو الحسن الأشعري(r) والباقلاني(r) قد ذهبا إلى قبول الصفات

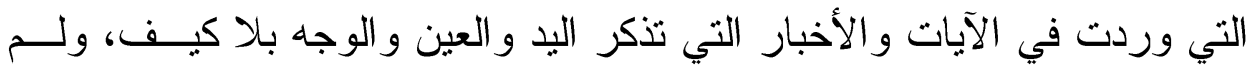
يقوما بتأويل شيء منها، فإنّ إمام الحرمين الجويني قد أولّ هذه الآيات وصرفها ولها

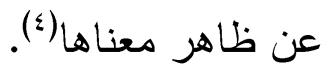
يدل على ذلك ما ورد في كتابه (الإرشاد)، إذ يقول:اذهبب بعض أئمتنــا

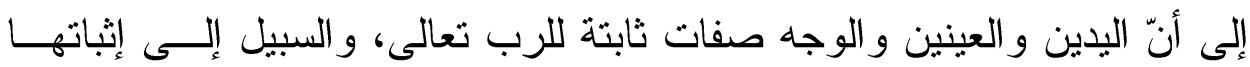
السمع دون قضية العقل. و الذي يصح عندنا حمل اليدين على القــدرة، وحمـلـل العينين على البصر ، وحمل الوجه على الوجوده(').

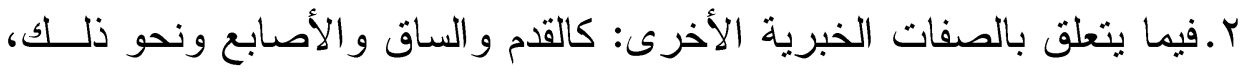

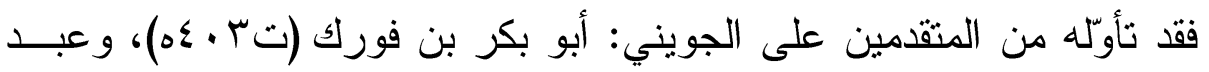

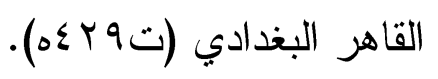

ثم جاء الجويني فأكد هذ الاتجاه التأويلي وطوره؛ إذ لم يكتف بالتأويل بل

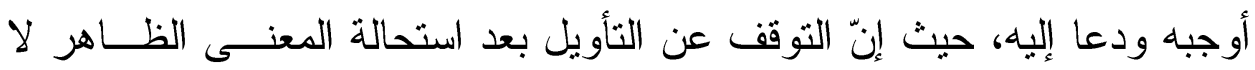
يخلو من أخطار.

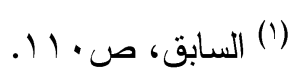

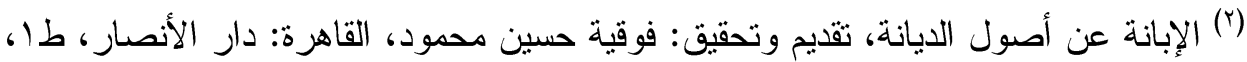

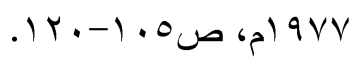

(") عبد الغني، نطور الدذهب الأشعري على يد الباقلاني، رسالة ماجستير، ص ال10ل 10 ـ وأيضا: صـ 10.

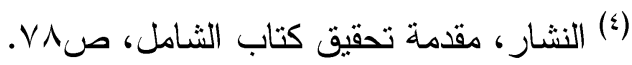

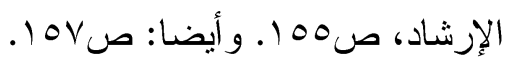


فيقول: او إذا أزيل الظاهر قطعا فلابد بعده في حمل الآية على محمـل

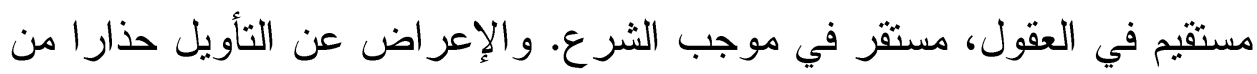
مو اقعة محذور في الاعتقاد يجر إلى اللبس و الإيهام، واستز لال العوام، وتطريق الثبهات إلى أصول الدين، وتعريض بعض كتاب الله تعالى لرجم الظنونها' (1).

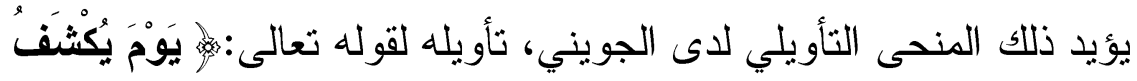

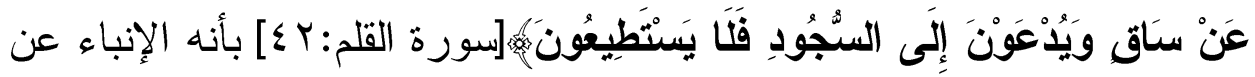

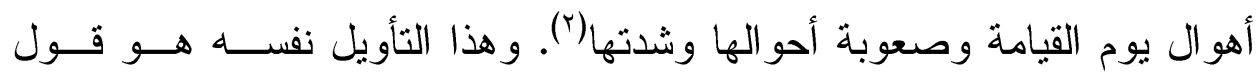

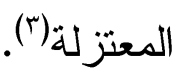

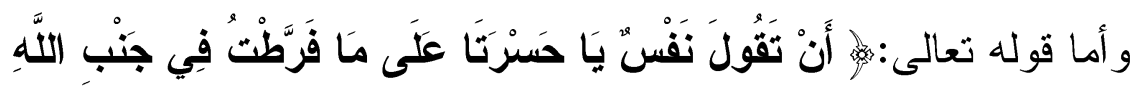

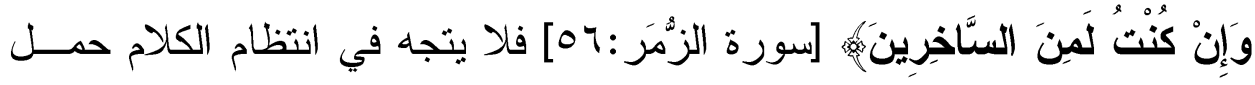
الجنب على تقدير الجارحة(؛)، وإنما يُحمل الجنب على جهات أمر الهه ومأخذها، وقد ير اد به الجناب و الذر|(*). ومال الجويني إلى منع أن تكون هذه الأمور صفات قديمة لله تعالى، بل بل بله يجب صرفها عن المعنى الظاهر إلى معان تليق باله تعالى، المنزه عن أي شبه

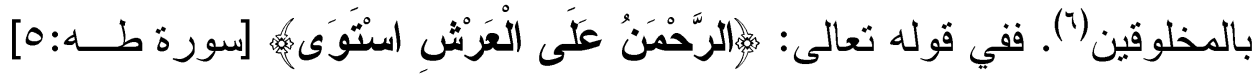
يذكر الجويني أنّ المر اد بالاستو اء القهر و الغلبة والعلو (Vان.

$$
\begin{aligned}
& \text { (1) (الإششاد، صبع. } \\
& \text { (") الإرشاد، ص109. الإنشاد صكا. }
\end{aligned}
$$

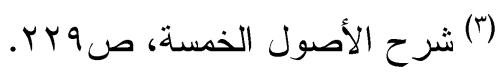

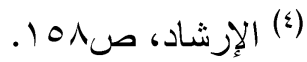

$$
\begin{aligned}
& \text { (1) (1) السابق، ص109، صل 101. }
\end{aligned}
$$

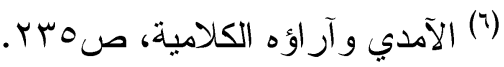

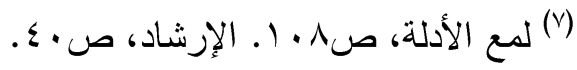


وقد استتد في تأويله هذا على التحليل اللغوي، فيذكر أنه 》الم يمتتع منـــا

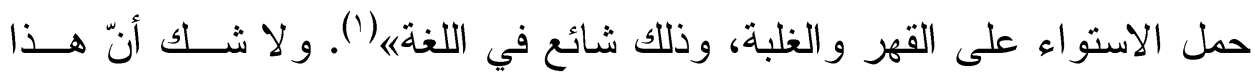
التأويل هو قول المعتزلة(؟). س. وفي رأي الجويني، ما يُلزم الأشاعرة بضرورة تقفيّ طريقة واحدة، إما إثبات هذه الصفات أو تأويلها جميعا، فيقول: (اهن سلك من أصحابنا سبيل إثبات هذه الصفات(َ) بظو اهر هذه الآيات ألزمه ســوق كلامـــه أن يجعــل الاســتو اء و المجيء و النزول و الجنب من الصفات، تمسكا بالظاهر، فإن ساغ تأويلهــا فيما يتفق عليه، لم يبعد أيضا طريق التأويل فيما ذكرناهه(؛).

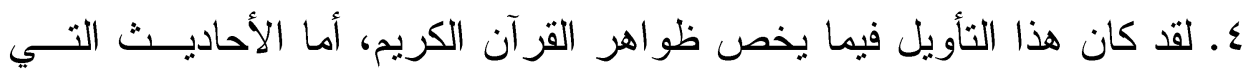
وردث منطوية على أمثال هذه الصفات، فما هو موقف الجويني منها؟

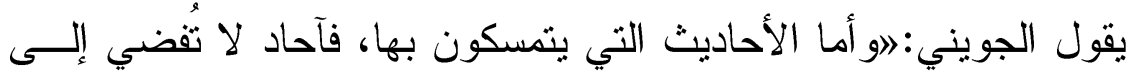
العلم، لو أضربنا عن جميعها لكان سائغا، لكنا نوميء إلى تأويل ما دون منها في الصحاح") (0) كحديث النزول مثنا. يتبين مما سبق، أنّ الجويني يمثل علامة فارقة فـي تــاريخ المـذهب الأشعري؛ لأنه يمثل مرحلة تحول منهجية بـين منقــدمي المـذهب الأشــعري و متأخريه، فإذا كان متقدمو المذهب(؟) يميلون في منهجهم نحو التمسك بــالنص و تقديمه على سائر الأدلة، فإنّ المتأخرين موفي مقدمتهم الجويني ذاته- مالو إلى

$$
\begin{aligned}
& \text { (1) (الإرشاد، ص. • ع. }
\end{aligned}
$$

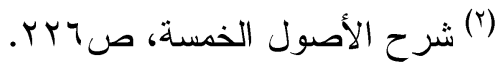

$$
\begin{aligned}
& \text { (") يقصد الوجه و العين و اليدين. }
\end{aligned}
$$

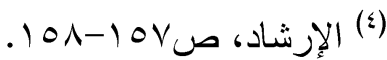

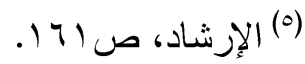

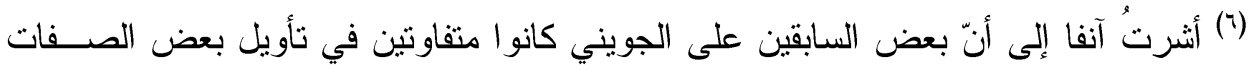
الخبرية دون غيرها، أما الجويني فقد أول جميعها. 
الأخذ بالمنهج الاعتز الي في تأويل النص و إخضـاعه لمـــلول العقـل(')، حتــى أضحى منهجهم جد قريب من منهج المعتزلة(r).

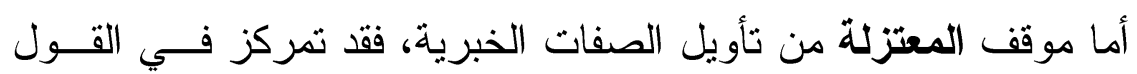

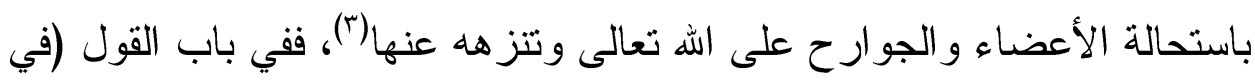

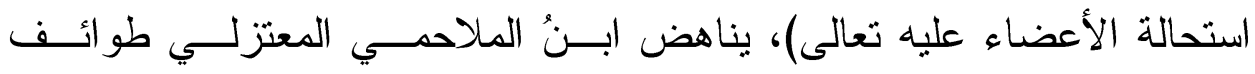
الأشعرية و الكلابية، و المجسمة، و الكر امية، فيقول: اذهب شيوخنا وجماعة غير هم ممن لا يقول بالتشبيه إلى أنّ الأعضاء تشتحيل على اله تعالى، وذهبت المجسمة ولهيه

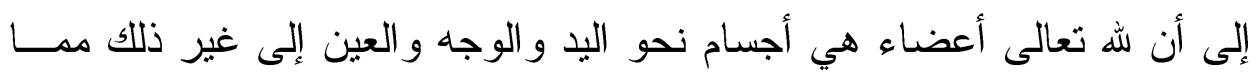

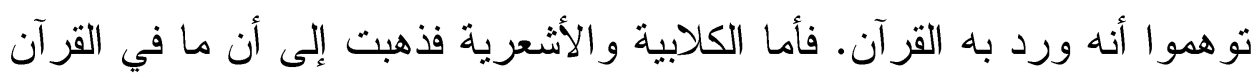

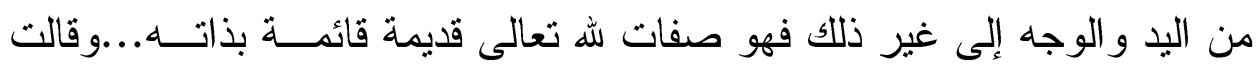
الكر امية: إنا لا نعرف معاني ما ورد به القرآن من إضافة الجوارح إليه تعالى،

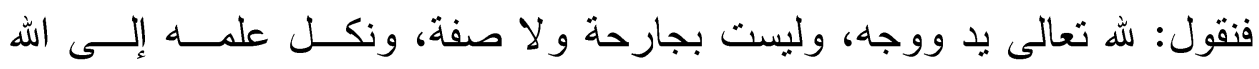
تعالى") (£).

ثم أفرد جانبا للرد على هذه المذاهب والفرق، فيرد على الأشعرية بأنــهـ ليس في الآيات التي يستندون إليها ما يدل على الصفات التي يذهبون إليها؛ لأنه

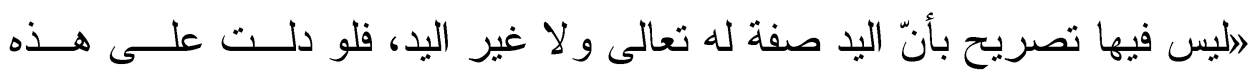
الصفات لدلت عليها إما بحقيقتها أو مجاز ها، وحقيقتها إنما تقتضي ما يذهب لهب إليه

المشبهة، ومجاز ها يشهد لما نتأولها عليهی(ن).

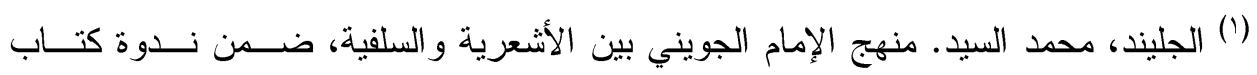

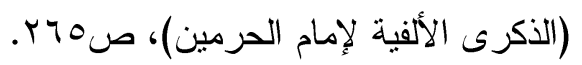

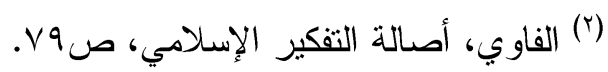

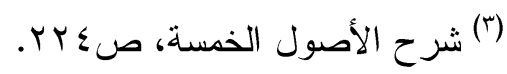

$$
\begin{aligned}
& \text { (؛) المعتمد في أصول الدين، صوح الاصول }
\end{aligned}
$$

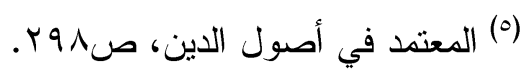


أما إبطال حجج المجسمة -الذين أثبتوا لله تعالى أعضاء على الحقبقة يدا

ووجها إلى غير ذلك- فقد جاء عبر المعطيات النالية:(') أ- لما ثبت أنه تعالى واحد على الحقيقة، فلا تجوز عليه الأبعاض و الأعضاء.

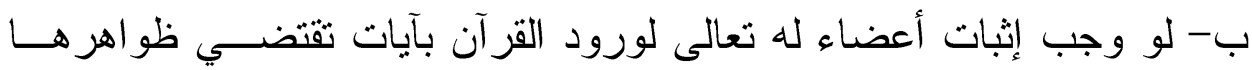

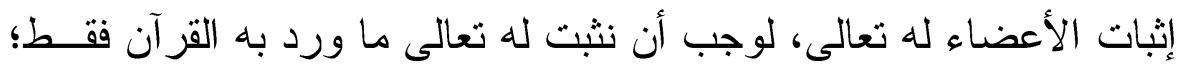
لأنه لا دليل على ما زاد على ذلك، أما باقي الأعضاء التي لم تـــكر فـي آلـي القرآن ووردت بها الأخبار عن الرسول سصلى الله عليه وسلم- فهي أخبار آحاد لا تفضي إلى العلم.

وكان التحليل اللغوي حاضرًا في تأويلاتهم()، فقام متـــأخرو المعتزلـــة بتأويل هذه الصفات وفقا للغة العرب، فاليد قد تكون بمعنى النعمة، وقــد تكـــون

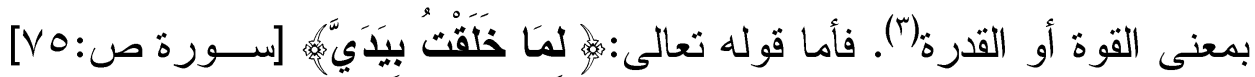
فيحتمل أن تكون البد في الآية بمعنى القدرة، ويحتمل أن تكون تأكيدا وصلة، أي خلقته أنا(६) وهكذا يلحظ المقارن بين تأويل المتأخرين من الأشاعرة وتأويل المعتزلة تقاربا و اتفاقا بينهما()، فالجويني اقترب سبوضوحِ- من المعتزلة بصدد الصفات الخبرية(؟). فلقد حرص هؤلاء المتأخرون من الأشاعرة على تأويل كل الصفات الخبرية التي قد توهم التشبيه كاليد والعين ونحوهما، سواء ما تعلق منها بالتغير

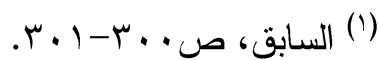

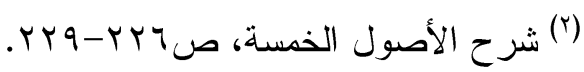

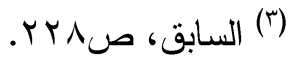

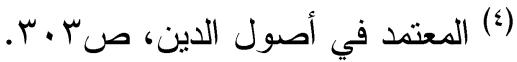

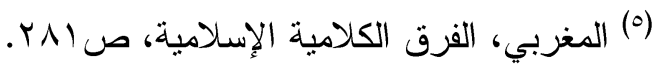

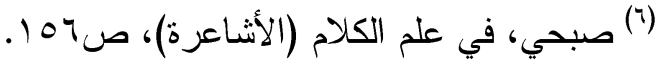


وحدوث شيء في الذات الإلهية، أو ما أو هم تشبيها بالمحدثات، وخاصة الجسمية ولوازمها. وهم في هذا يتفقون مع المعتزلة ما عدا إثبات الرؤيــة(1)، إذ تتفــي المعتزلة رؤية الله في الآخرة.

\section{تمقفيــبـ:}

يُظهر هذا البحث نصرة إمام الحرمين الجويني و اعتناقه لعدد مـن آراء

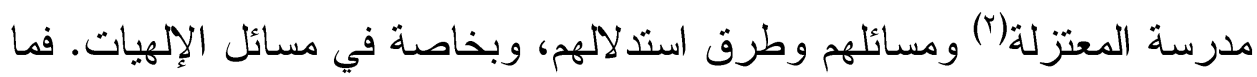
هي أسباب التحول التي دفعته إلى الركون إلى هذا المسلك حتى يكاد يعبر عـنـ روح اعتز الية أصيلة، رغم أنه عاش أشعريا طول حياته ولم يصر ح مطلقا بأنه

معتزلي؟

ولإجابة عن هذا التساؤل، أقول: من الطبيعي أن تشاير آراؤه و اعتقاداته المشهور والمتداول في المذهب الأشعري، بيد أنّ جودة القريحة، وكثرة النظـــر

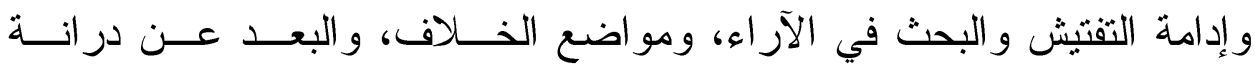

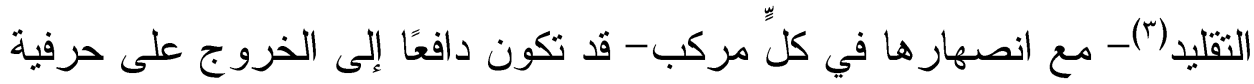
المذهب وظاهريته. و هذا بيّن في شخصية( )ُ الجويني وخصائصها.

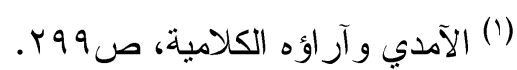

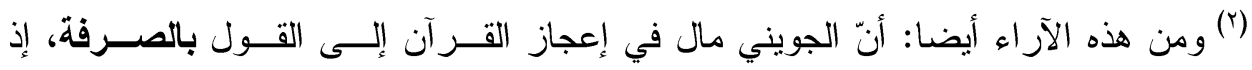

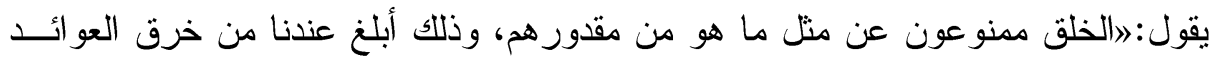

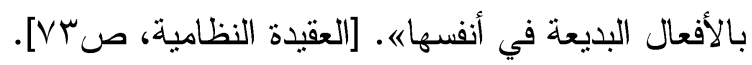

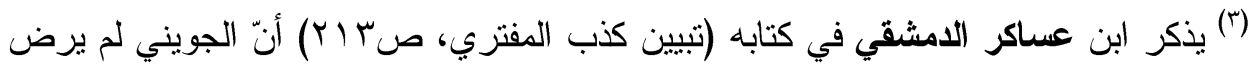

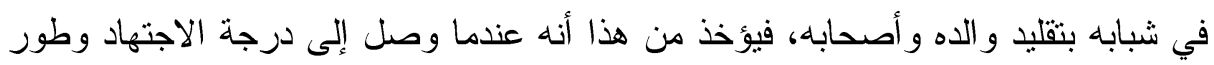
التحقيق فسيكون أكثر ثورة وهجوما على التقليد و المقلدين. (؛) اهنت علي سامي النشار بييان العناصر المكونة لشخصية الجويني، وأرجعها إلــى ثلاثــة

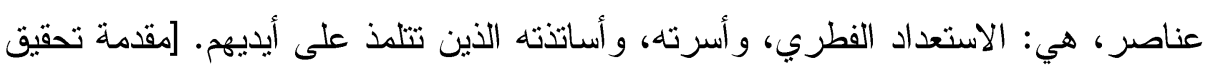
الثامل، ص • V] 
كذلك، فمن المحتمل أنه استقى هذه الآراء و الأفكار من خارج المـذهب الأشعري إيمانًا منه بقوتها وجديتها، واتساقها مع العقل، و استجابة لروحه النقدية

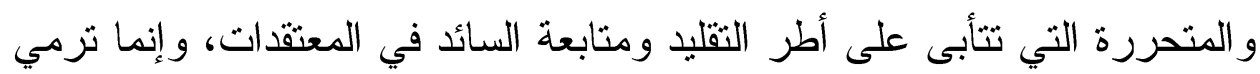
إلى التماس الحق من مظانه أيا كانت. وربما كان يهدف إلى تأييد مو اقفه تلك بما انقدح لله من أدلـــة وبــر اهين

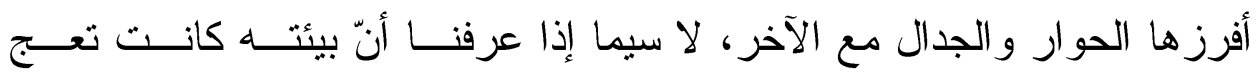

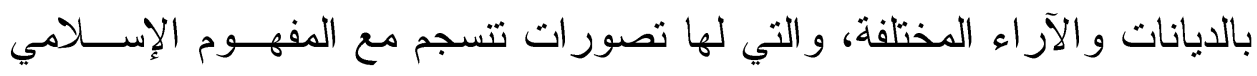
حينا، وتخالفه أحايين كثيرة. 


\section{خاتمــــة}

في هذا البحث الموسوم بعنوان "القلسفة الإمهية عنــــ إمــام الحـــرمين

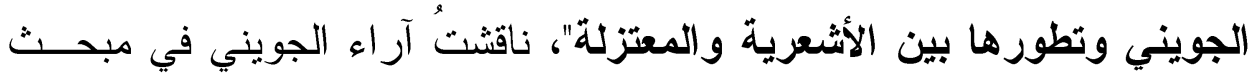
الإلهيات، وبعض مناحي التطور في المذهب الأشعري، مبينا أثر المعتزلة فـي البناء الكلامي للجويني، وقد تمخض ذلك عن عدد من النتائج، منها: 1- تقلصت مساحة الاحتجاج بالنقل على يد الجويني، في مقابل التوسع من نطاق

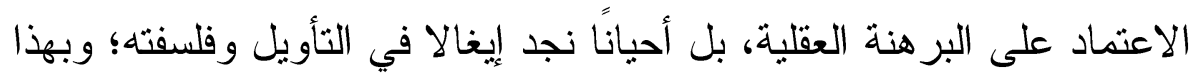
التوجه العقلاني يكون ممهدا لمرحلة التمازج و الاختلاط بين الكلام و الفلسفة من جهة، و الاقتراب من المنهج الاعتز الي من جهة أخرى. ץ-يمثل الجويني علامة فارقة في تاريخ المذهب الأشعري وتطور أفكاره؛ لأنه

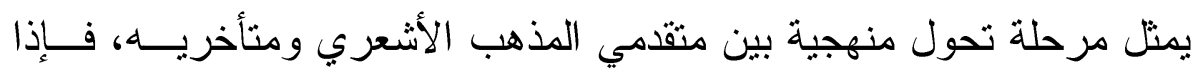
كان منقدمو المذهب يميلون في منهجه نحو التمسك بالنص وتقديمه علــى سائر الأدلة، فإن متأخريهح مو الجويني على رأسهر - مالو ا إلى الأخذ بالمنهج الاعتز الي في تأويل النص و إخضاعه لمدلول العقل. ب-تبنى الجويني فكرة الدور التي نشأت في أحضان الفكر الاعتز الي، ونرتــبـ

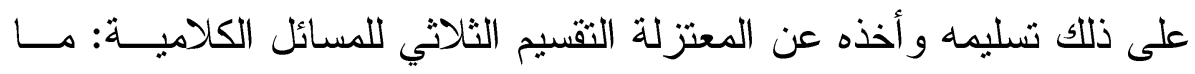
يدرك بالعقل وحده، وما يدرك بالسمع وحده، وما يدرك بهما معا، ناهيك عن

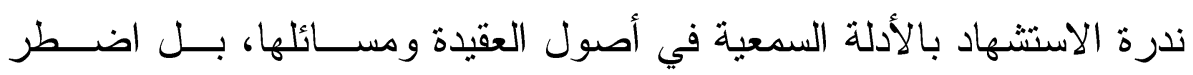
الجويني للدفاع عن أبي الحسن الأشعري و الباقلاني في احتجاجهما بالســـع

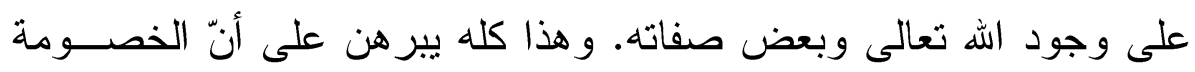
المذهبية لم تقف حائلا دون علاقات التأثير و التأثر في الأسس المنهجية، وأن ظاهرة تبادل الأفكار بين هاتين المدرستين أمر مألوف.

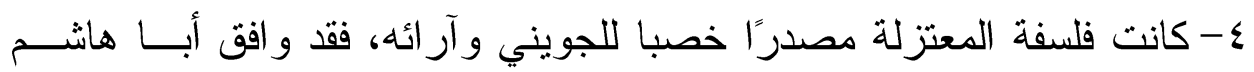
الجبائي في القول بنظرية الأحو ال و الرد على منكريها. 
كذلك تجلى هذا الأثر الاعتز الي، في تدعيمه البناء الكلامــي للمـذهب الأشعري بالحجج العقلية، وفي مقدمتها توظيفه لقياس الغائب على الثـــاهد فــي إثبات بعض الصفات، وهو من طرق المعتزلة. و هذا في رأي الباحث لا يعيب الجويني و لا يؤاخذ به، فربما استقى هذه

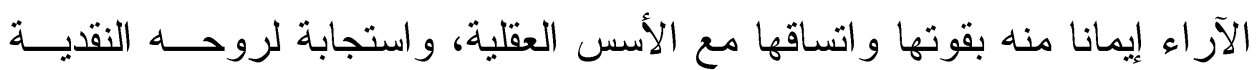
و المتحررة التي تتأبى على التقليد ومتابعة السائد في المعتقدات. 0-في قضية إثبات وجود الله، استدل الجويني بدليلين هما: دليل الحدوث عـنـ

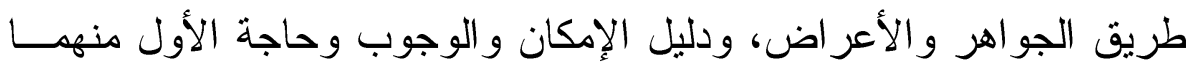

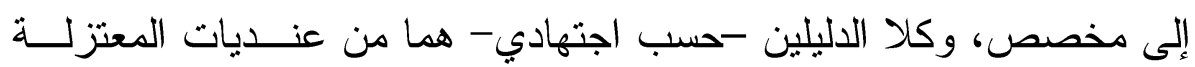
و استتباطاتهم، رغم ما نلحظه -لأول و هلة- من اصطباغهما بروح فلسفية. צ- حرص الجويني على تأويل كل الصفات الخبرية التي قد توهم التشبيه كاليد

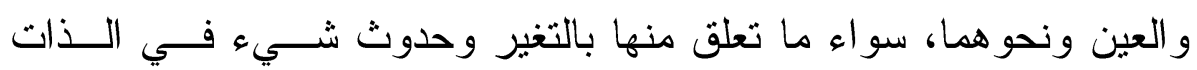

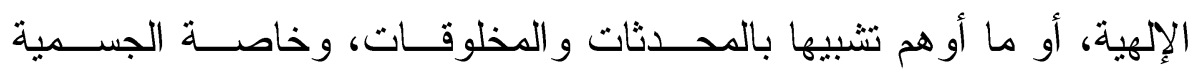
ولو ازمها. ولعله في هذا يتفق مع المعتزلة حاشا مسألة إثبات الرؤية. V- لم يكن الجويني بدعًا في موافقة المعتزلة في بعض مسائل الإلهيات، بل حذا حذوه منأخرو الأشاعرة كالغز الي و الرازي. وأوصي في ختام هذا البحث بضرورة أن ننظر في تــراث المتكلمــين

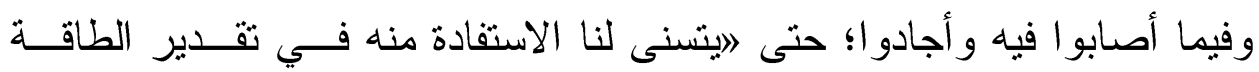

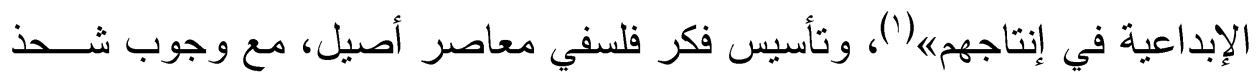
الحاسة النقدية في فهم النصوص و إدر اك مر اميها.

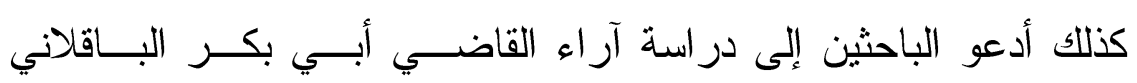

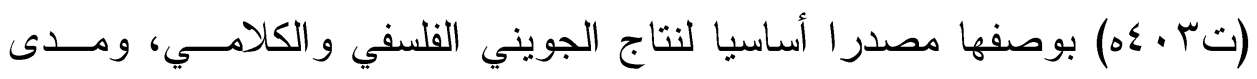
صلتها بالتز اث الاعتز الي وفلسفته. 


\section{ثبت المصادر والمراجع}

\section{أولا_ المصادروالمراجع (باللفة العربية):}

ا. الآلكوسي: حسام الدين (دكتور)، حوار بين الفلاسفة والمتكلمين، بغـــاد: دار

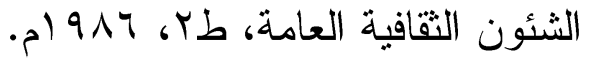

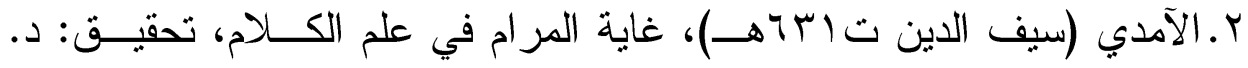

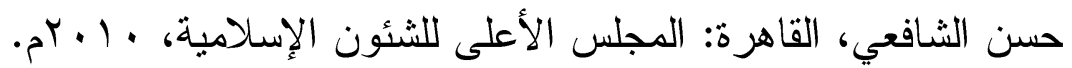

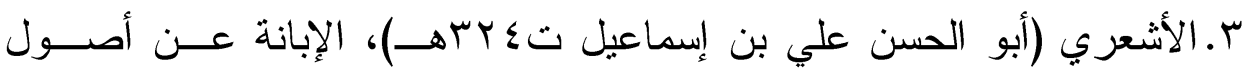

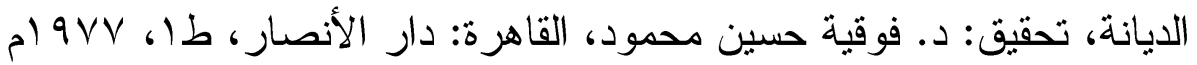

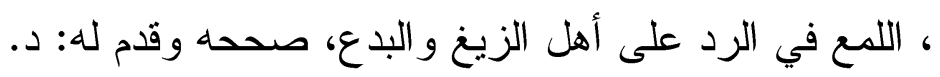

حمودة غر ابة، القاهرة: مطبعة مصر، 900 ام.

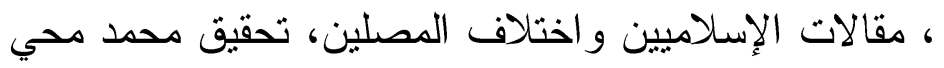
.0

الدين عبد الحميد، القاهرة: مكتبة النهضة المصرية، طا، ـ 90 (ام.

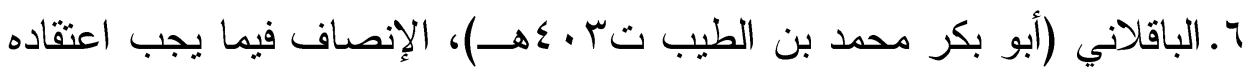
و لا يجوز الجهل به، تحقيق وتعليق: محمد زاهد الكوثري، القاهرة: المكتبــة الإنها

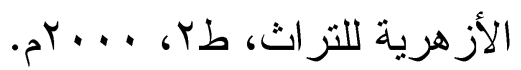

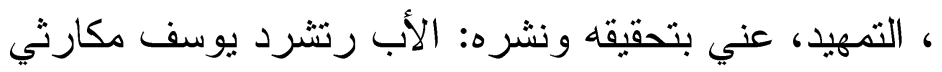
.$\vee$

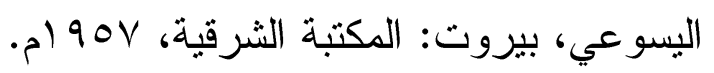

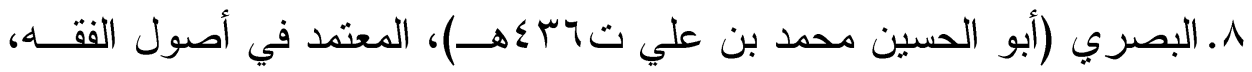

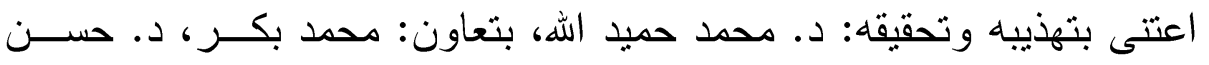

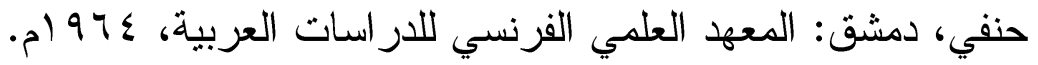

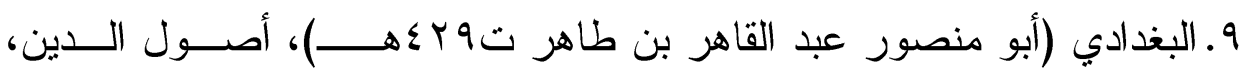

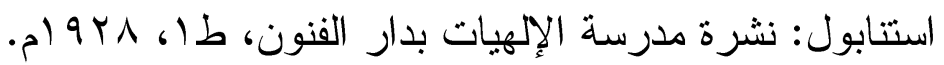

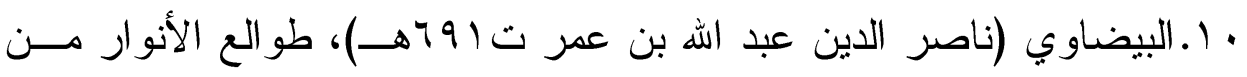

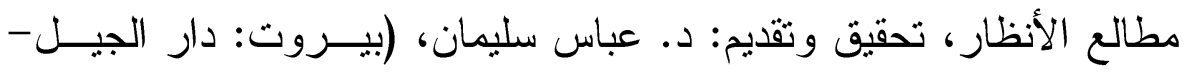
القاهرة: المكتبة الأزهرية للتراث)، طا، 999 (ام. 
11 ـالتفتاز اني: أبو الوفا (دكتور)، علم الكلام وبعض مشــكلاته، القــاهرة: دار الثقافة، بدون تاريخ.

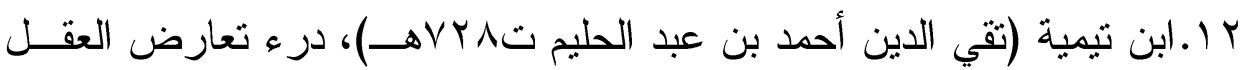
و النقل، تحقيق: د. محمد رشاد سالم، القاهرة: مكتبة ابن تيمية، بدون تاريخ. ، منهاج السنة النبوية، تحقيق د. محمد رشاد سالم، مؤسسة .14

\section{قرطبة، طا، 7 ، ع اهـ.}

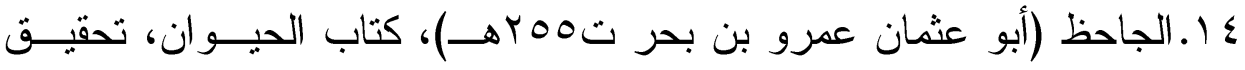
وشرح: عبد السلام هارون، القاهرة: مكتبة مصطفى البابي الحلبـي، طب، . 1970

1 ا.الجليند: محمد السبد (دكتور)، قضية الألوهية بين الدين و الفلسفة، القــاهرة:

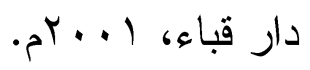

، منهج الإمام الجويني بين الأشعرية و السلفية، ضمن كتاب .17

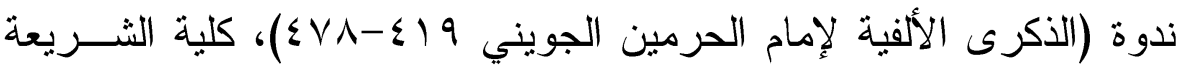
و القانون و الدر اسات الإسلامية، جامعة قطر، أبريل 999 ام.

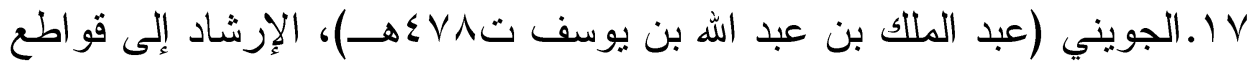
الأدلة في أصول الاعتقاد، حققه وعلق عليه: د. محمد يوسف موسى، علي عبد المنعم، القاهرة: مكتبة الخانجي، .90 (م. ، البرهان في أصول الفقه، حققه وقدمه ووضـع فهارســه: .11 د. عبد العظيم الديب، قطر : إدارة الشئون الدينية، طا، 99 إهـــ ، الشامل في أصول الدين، حققه وقدم له: د. علي ســامي .19 النشار، د. فيصل عون، د. سهير مختار، الإسكندرية، منشـــة المعـارف، دئ

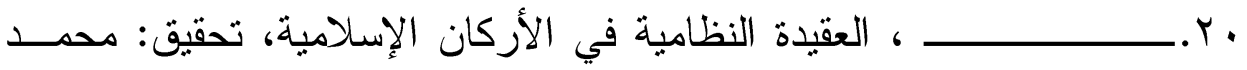

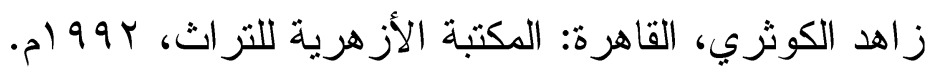


، لمع الأدلة في قو اعد عقائد أهل السنة والجماعة، تقــديم . I I

وتحقيق: د. فوقية حسين محمود، بيروت: عالم الكتب، طب، 9^V ام. Y Y. الحاكم الجشمي (أبو السعد المحسن بن كرامة تع 9؛هــ)، الطبقتان الحادية عشرة و الثانية عشرة من شرح العيون، ضمن كتــاب (فضـــل الاعتــز ال وطبقات المعتزلة)، تحقيق: فؤاد سيد، الدار التونسية للنشر، بدون تاريخ.

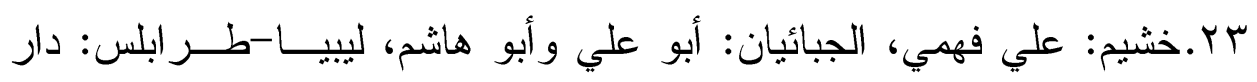

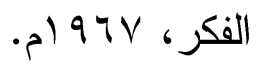

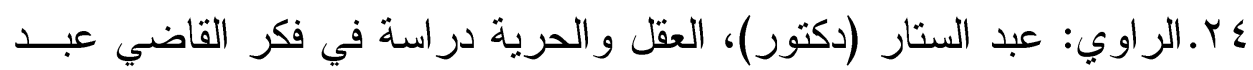
الجبار المعتزلي، بيروت: المؤسسة العربية، طاه، • 919 ام.

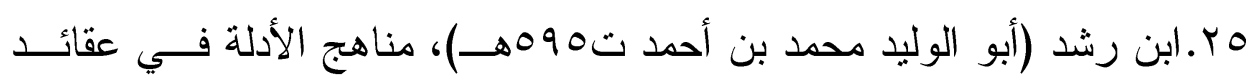
الملة مع مقدمة في نقد مدارس علم الكلام، تقديم وتحقيق، د. محمود قاسم، القاهرة: مكتبة الأنجلو المصرية، 999 ام.

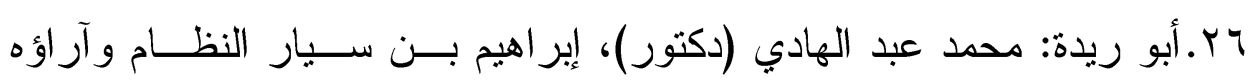
الكلامية الفلسفية، الهيئة المصرية العامة للكتاب، • 1 • بوم.

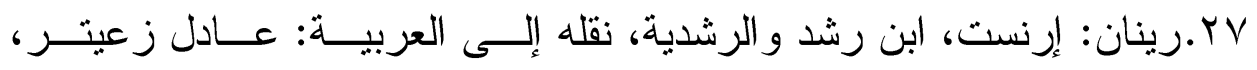

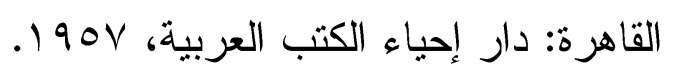

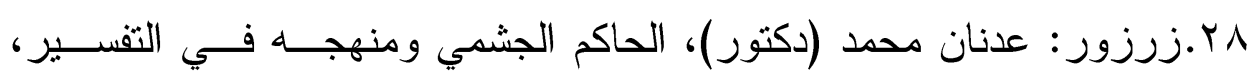
بيروت: مؤسسة الرسالة، بدون تاريخ. وץ. الزركان: محمد صالح، فخر الدين الرازي و آراؤه الكلامية و الفلســفية، دار

$$
\text { الفكر، بدون تاريخ. }
$$

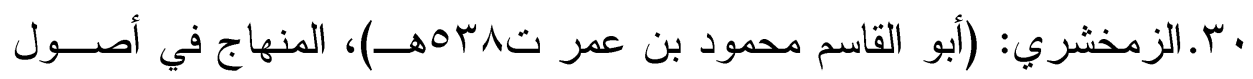

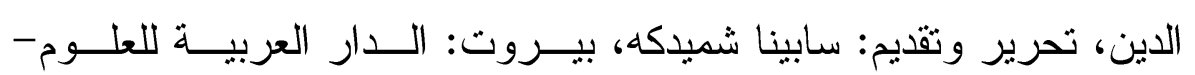

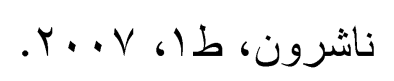

اس.أبو زيد: منى أحمد (دكتورة)، الفكر الكلامي عند ابن خلـدون، بيــروت: المؤسسة الجامعية، ط ا، ل99 ام. 


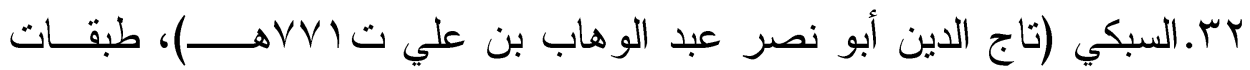

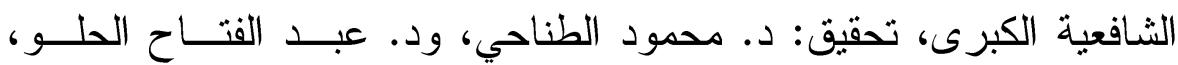

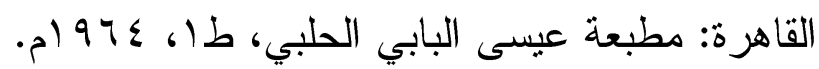

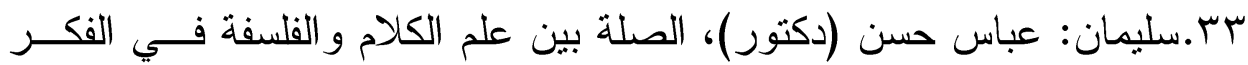
الإسلامي، الإسكندرية: دار المعرفة الجامعية، 991 ام. ع. السبد: محمد صالح (دكتور)، أصالة علم الكلام، القاهرة، دار الثقافة و النشر، الإسن، . $919 \mathrm{~V}$ هب. الثافعي: حسن (دكتور)، الآمدي و آراؤه الكلامية، القــاهرة: دار الســلاح، ط ط ، المدخل إلى در اسة علم الكلام، القاهرة: مكتبـــة وهبــة، .ry

\section{طبا، بدون تاريخ.}

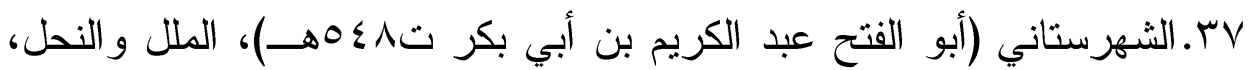

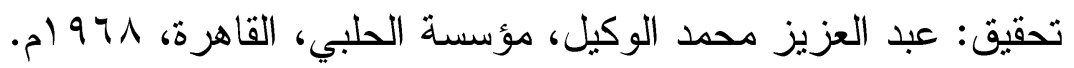

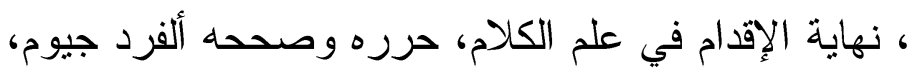
.$r \Lambda$

\section{بدون بيانات.}

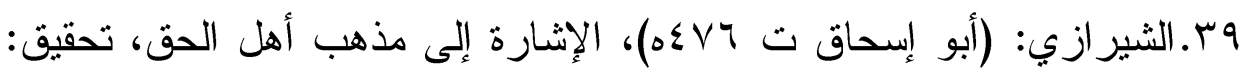

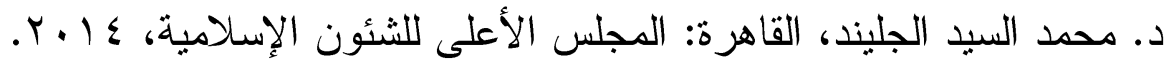
• ع.صبحي: أحمد محمود (دكتور)، في علم الكلام، دراسة فلسفية لآر اء الفــرق الأه الإسلامية في أصول الدين، "ب" الأشاعرة، بيروت: دار النهضية العربيــة . 910 ط

، في علم الكلام، در اسة فلسفية لآر اء الفرق الإسلامية، " ا"

المعتزلة، الإسكندرية، مؤسسة الثقافة الجامعية، طع، ب 91 ام.

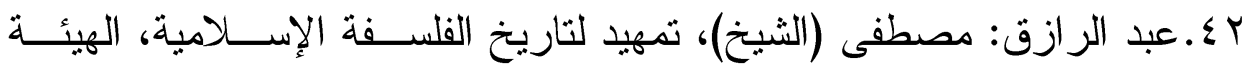

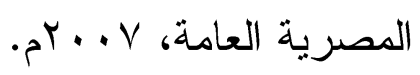

rـ.عبد الرحمن: طه (دكتور)، في أصول الحوار وتجديد علم الكــلام، الـــدار البيضاء: المركز الثقافي العربي، طب، . .... 


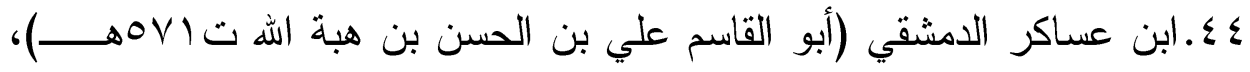
تبيين كذب المفتري فيما نسب إلى الإمام أبي الحسن الأشعري، قدم له و وعلق

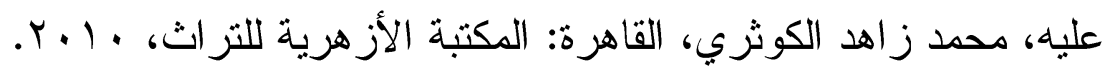

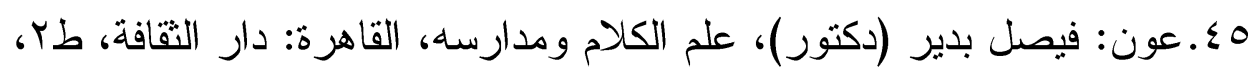
بدون تاريخ. جـ.الغالي: بلقاسم (دكتور)، أبو منصور الماتريــدي حياتــهـه وآراؤه العقديــة،

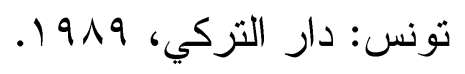
ع V غرديه: لويس، و الأب جورج قنواتي، فلسفة الفكر الــديني بـين الإســلام و المسيحية، نقله إلى العربية: د. صبحي الصالح، د. فريد جبر ، بيروت: دار العلم للملايين، بدون تاريخ.

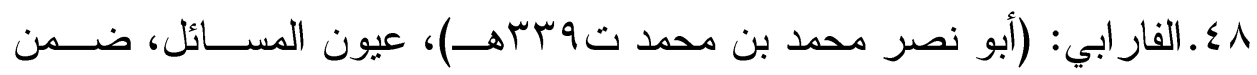

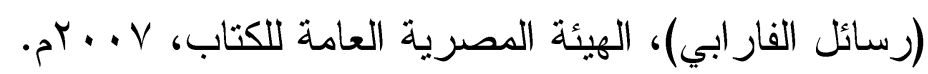

9ء.الفاوي: عبد الفتاح (دكتور)، أصالة التفكير الإسلامي فـــي علــم الكــلام،

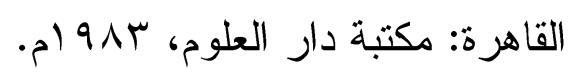
•. فتاح: عرفان عبد الحميد (دكتور)، فلسفة الفكر الديني وجهود إمام الحرمين

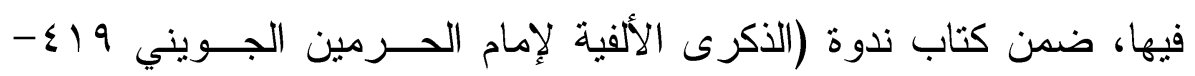

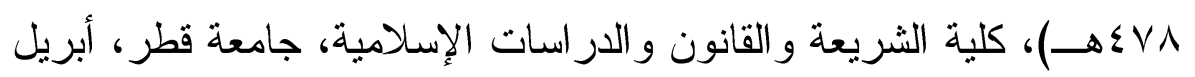
. $) 999$

01.فؤاد: عبد الفتاح أحمد (دكتور)، الفرق الإســلامية وأصـــولها الإيمانيــة،

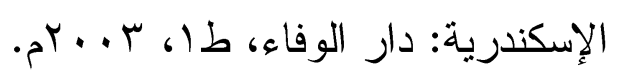

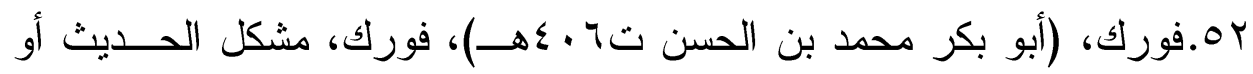

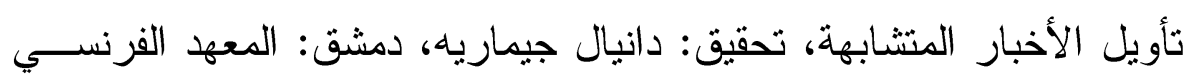

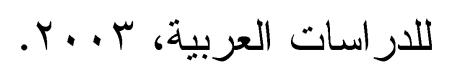

سه.قاسم: محمود (دكتور)، ابن رشد وفلسفته الدينية، ضدن (د. محمود قاســم: الأعمال الكاملة)، الهيئة المصرية العامة للكتاب، V V إبم، المجلد الأول. 
ع. قوشتي: أحمد (دكتور)، الاليل النقلي في الفكـر الكلامهـي بــين الحجيــة و التوظيف، الرياض: الجمعية العلمية السعودية للار اسات الفكرية المعاصرة، .

00.القوصي: محمد عبد الفضيل(دكتور)، هـــوامش علــى العقبــدة النظاميــة

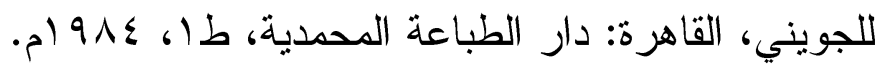

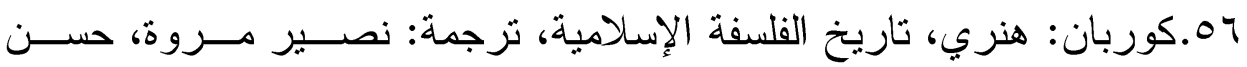

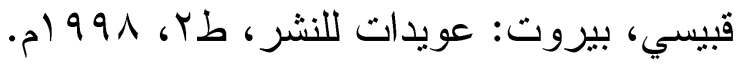

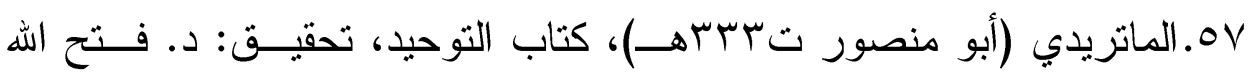
خليف، الإسكندرية، دار الجامعات المصرية، بدون تاريخ.

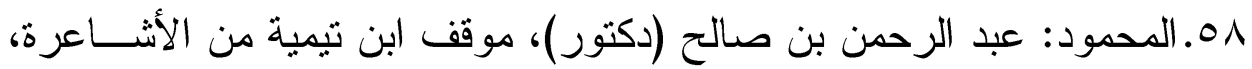

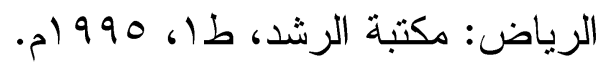
09.محمود: فوقية حسين (دكتورة)، الجويني إمام الحرمين، الهيئــة المصــرية

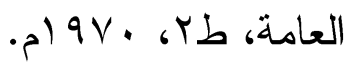
• 7.مدكور : إبر اهيم (دكتور)، في الفلسفة الإسـامية منهج وتطبيةــه، القــاهرة: سميركو، طب، بدون تاريخ، الجزء الثاني.

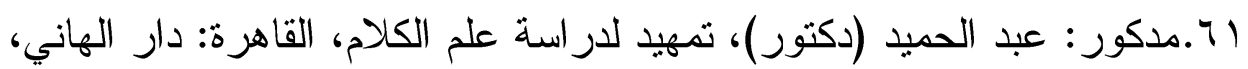
. 1 . بآ.ـر اد: سعيد (دكتور)، مدرسة البصرة الاعتز الية، القاهرة: مكتبــة الأنجلــو

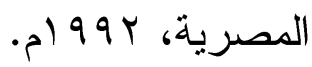

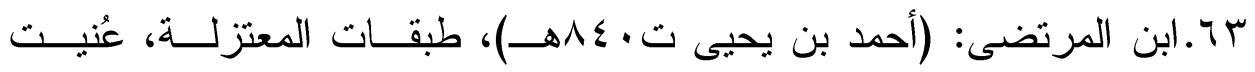

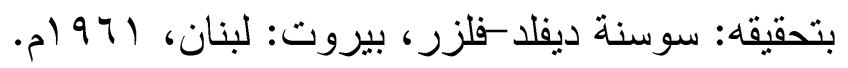

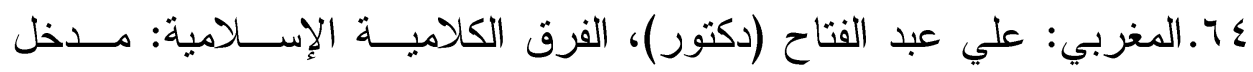

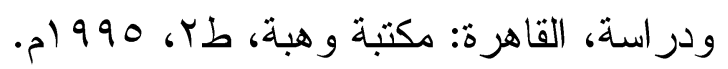

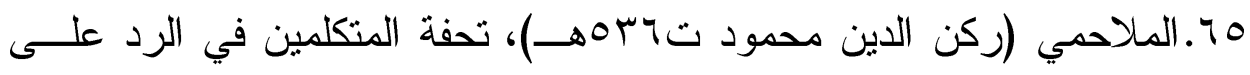

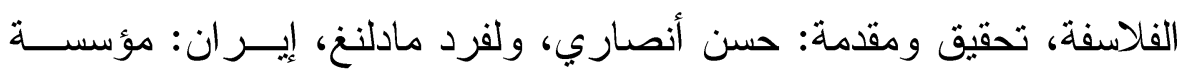
بزو هشي حكمة وفلسفة، بدون تاريخ. 
، الفائق في أصول الدين، حققه وقدم له: د. فيصل بــدير .74

$$
\text { عون، القاهرة: دار الكتب و الوثائق القومية، • 1 + ·rم. }
$$

V.TV

$$
\text { - م) } 990
$$

1 7.ميهوب: سيد عبد الستار (دكتور)، أبو رشيد النيسـابوري وآراؤه الكلاميــة

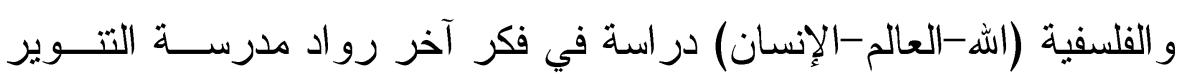

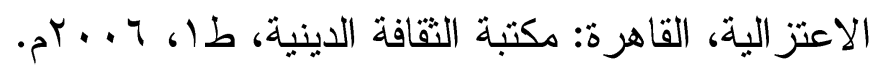

79. النجر اني (تقي الدين، توفي في القــرن الســابع الهجــري)، الكامــل فـي الاستقصاء فيما بلغنا من كلام القدماء، دراسة وتحقيق: د. الســـيد الثـــاهد،

$$
\text { القاهرة: المجلس الأعلى للشئون الإسلامية، } 999 \text { ام. }
$$

•V.النشار : علي سامي (دكتور)، مناهج البحث عند مفكري الإسلام و اكتشـاف المنهج العلمي في العالم الإسلامي، الإسكندرية: دار المعرفة الجامعية، طس، . $) 999$

، نشأة الفكر الفلسفي في الإسلام، القاهرة: دار المعــارف،

$$
\text { . } 999 \cdot 69
$$

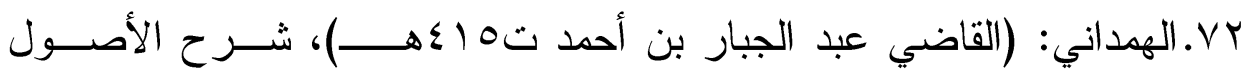

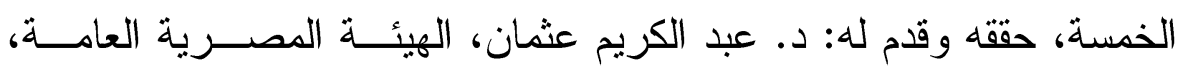

$$
\cdot r^{2} \cdot q
$$

، المحيط بالتكليف، جمع الحسن بن أحمد بن منوية، تحقيق .$V T$

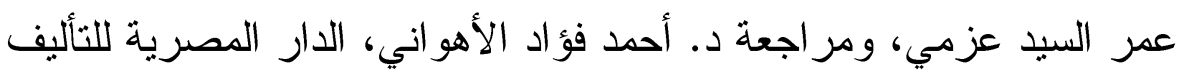

$$
\text { و الترجمة، بدون تاريخ، المجلد الأول. }
$$

، المغني في أبو اب التوحيد و العدل (التتبؤات و المعجزات)، . $v \varepsilon$

تحقيق: د. محمود قاسم، ومر اجعة: د. إبر اهيم مــدكور، الــدار المصــرية للتأليف و الترجمة، الجزء الخامس عشر . 
، المغني في أبو اب التوحيد و العدل (الشرعيات)، أثـــرف Vo على إحيائه: د. طه حسين، الدار المصرية للتأليف و الترجمة، الجزء السابع عشر · م

TY..ولفسون: (هاري. أ)، فلسفة المتكلمين، ترجمة: د. مصــطفى لبيــب عبـــ

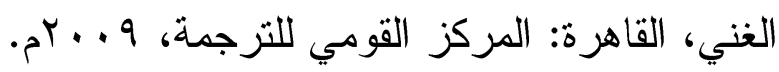

\section{ثانيا_ المراجع الأجنيبة:}

- Davidson: Herbert A: Proofs for Eternity, Creation and the Existence of God in Medieval Islamic and Jewish Philosophy, (Oxford University Press 1987).

- Fakhry: Majid, The Classical Islamic Argument for the Existence of God, The Muslim World, april 1957.

\section{ثالثاـ المجلات والدوريات العلمية:}

ا-سالمان: حمادة محمد إبــر اهيم (دكتــور)، حريــة الإز ادة لــدى الإمــامين

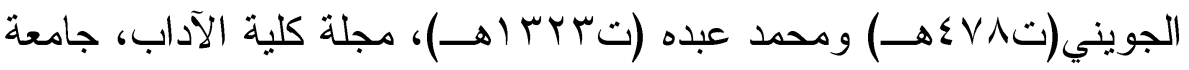

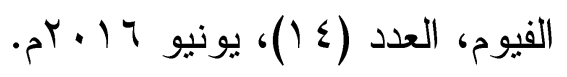

r- مادلونغ: ويلفرد، أبو الحسين البصري وبر اهين وجود الله، مجلة التســامح،

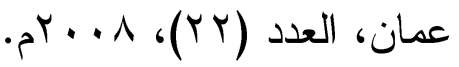

\section{رابعاـ الرسائل العلمية:}

1- حميدة: محمود سعيد، ظاهرة التحول في الفكر الكلامي عند الأشاعرة حتـى نهاية القرن السابع الهجري، رسالة ماجستير (غيــر منشــورة)، كليــة دار

$$
\text { العلوم، جامعة القاهرة، V V. . آم. }
$$

Y- عبد المقصود: عبد المقصود عبد الغني، تطور المذهب الأشعري على يـــ الباقلاني، رسالة ماجستير (غير منشورة)، كلية دار العلوم، جامعة القاهرة، 